\title{
Reducing Suicide by Providing Cognitive Behavioral Therapy for Suicide Prevention
}

Wendy Larkin

University of St. Augustine for Health Sciences, w.larkin@usa.edu

DOI: https://doi.org/10.46409/sr.PONV6612

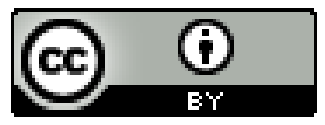

This work is licensed under a Creative Commons Attribution 4.0 License.

Follow this and additional works at: https://soar.usa.edu/scholprojects

Part of the Cognitive Behavioral Therapy Commons, Psychiatric and Mental Health Commons, Psychiatric and Mental Health Nursing Commons, and the Psychology Commons

\section{Recommended Citation}

Larkin, W. (2020). Reducing Suicide by Providing Cognitive Behavioral Therapy for Suicide Prevention. [Doctoral project, University of St Augustine for Health Sciences]. SOAR @ USA: Student Scholarly Projects Collection. https://doi.org/10.46409/sr.PONV6612

This Scholarly Project is brought to you for free and open access by the Student Research at SOAR @ USA. It has been accepted for inclusion in Student Scholarly Projects by an authorized administrator of SOAR @ USA. For more information, please contact soar@usa.edu, erobinson@usa.edu. 
Reducing Suicide by Providing Cognitive Behavioral Therapy for Suicide Prevention (CBT-SP) in the Outpatient Setting

\author{
Wendy D. Larkin, MSN, ARNP
}

School of Nursing, University of St. Augustine for Health Sciences

This Manuscript Partially Fulfills the Requirements for the

Doctor of Nursing Practice Program and is Approved by:

Kathleen Farrell, DNSc, RN

Pamela Bastiano, DNP, PMHNP-BC, RN

Betty Holte, DNP, MSN, ARNP

December 2020 
REDUCING SUICIDE BY PROVIDING COGNITIVE BEHAVIORAL THERAPY

\section{University of St. Augustine for Health Sciences \\ DNP Scholarly Project \\ Signature Form}

\begin{tabular}{|c|c|c|}
\hline $\begin{array}{l}\text { Student Last Name: } \\
\text { Larkin }\end{array}$ & $\begin{array}{l}\text { First Name: } \\
\text { Wendy }\end{array}$ & $\begin{array}{l}\text { Middle Initial: } \\
\text { D. }\end{array}$ \\
\hline \multicolumn{3}{|c|}{$\begin{array}{l}\text { E-mail: } \\
\text { W.Larkin@usa.edu }\end{array}$} \\
\hline $\begin{array}{l}\text { Title of DNP Project: } \\
\text { "Reducing Suicide by Providing Cogr }\end{array}$ & ral Therapy for Suicide Prevention (CBT & e Outpatient Setting" \\
\hline \multicolumn{3}{|c|}{$\begin{array}{c}\text { My signature confirms I have reviewed and approved this final written DNP Scholarly Project. } \\
\text { DocuSign electronic signature or wet signature required. }\end{array}$} \\
\hline Type Name in Blue Box Below & Signature & Date \\
\hline $\begin{array}{l}\text { DNP Project Primary Faculty: } \\
\text { Dr. Kathleen Farrell }\end{array}$ & Kathleen Farrell & $12 / 1 / 20$ \\
\hline $\begin{array}{l}\text { DNP Project Preceptor: } \\
\text { Dr. Pamela Bastiano }\end{array}$ & Pamela Bastiano & $12 / 1 / 20$ \\
\hline $\begin{array}{l}\text { DNP Project Preceptor: } \\
\text { Dr. Betty Holte }\end{array}$ & Betty Alolte & $12 / 1 / 20$ \\
\hline
\end{tabular}




\begin{abstract}
Veteran suicide is a serious and persistent national problem, which demands an effective treatment intervention. This Evidence-Based Practice project (EBP) addressed the question: Do patients with a psychiatric in-patient admitting diagnosis of suicidal ideation, who after discharge self-elect outpatient Cognitive Behavioral Therapy-Suicide Prevention (CBT-SP) treatment over a 6-week time frame, reduce the likelihood of hospital readmission for suicidal ideation vs. patients who decline CBT-SP treatment and elect Treatment as Usual (TAU)? The literature is prolific in validating that CBT-SP is successful in determining the effectiveness of CBT-SP versus TAU in reducing suicidal behaviors in adults. Hospital re-admission data were collected on both the CBT-SP and the TAU groups. The CBT-SP group collected a further measure utilizing the Quality of Life (QOL) Scale pre and post CBT-SP group intervention. Demographic variables of age, sex, and homelessness were compared to assess variability between the two groups. The CBT-SP and the TAU groups were compared for rehospitalization utilizing the Fisher exact test, which was statistically significant at $\mathrm{p}<0.05$ for no rehospitalizations in the CBT-SP group and six rehospitalizations in the TAU group over a 6-week period. The Wilcoxon Signed Rank Test was used to analyze the difference between the pre and post QOL scores within the CBT-SP group and the results demonstrated a statistically significant positive increase in QOL scores at $\mathrm{p}<0.004$. The only difference in the group demographic variables was for age, after utilizing a non-paired t-test results produced a significance at $\mathrm{p}<0.03$, with the CBT group mean age being approximately ten years younger than the TAU group. Evaluation of outcome measures confirmed a decrease in hospital readmissions for suicide ideation and/or attempt and an increase in quality of life scores for the CBT-SP group.
\end{abstract}




\section{Reducing Suicide by Providing Cognitive Behavioral Therapy for Suicide Prevention (CBT-SP) in the Out-Patient Setting}

Suicide rates in America are increasing. Suicide is now the 10th leading cause of death in America, claiming more lives than traffic accidents and twice as many lives as homicides (Sentinel Alert Event, 2016). Alarmingly, suicide rates have increased by 33\% from 1999 through 2017 (Center for Disease Control and Prevention: National Center for Health Statistics, 2019). Veteran suicide is also on the increase with $13.5 \%$ of Veterans accounting for all deaths by suicide in 2017 in the U.S. and constituted $7.9 \%$ of the U.S. adult population (US Department of Veteran Affairs, 2019) Hence, suicide prevention is a national Veteran Health Administration (VHA) priority and mission.

Cognitive behavioral therapy for suicide prevention (CBT-SP) is theoretically grounded and incorporates evidence-based practice principles of psychological therapy. CBT-SP is a 6-12 week therapy aimed to understand problems associated with the relationship between thoughts, physiological sensations, emotions, and behaviors (Bryan et al., 2018). This Doctor of Nursing Practice (DNP) project proposed a practice change for implementing evidence-based CBT-SP in the outpatient setting at a large East Coast VA hospital.

This 6-week EBP intervention compared CBT-SP versus Treatment as Usual (TAU) with post discharged psychiatric patients with an admitting diagnosis of suicidal ideation or attempt. The intervention involved an interprofessional team of mental health nurses, advance practice nurses, psychologists, licensed mental health counselors, and two DNP preceptors. The intervention explored the rehospitalization rates of the CBT-SP versus the TAU groups and the Quality of Life pre and post measures of the CBT-SP group. 


\section{Significance of the Practice Problem}

In 2017, United States Veteran suicide deaths were 6,139 (National Veteran Suicide Prevention Annual Report, 2019). According to the National Veteran Suicide Prevention Annual Report (2019), the number of Veteran suicide deaths has exceeded 6,000 each year from 2008 to 2017. Suicide prevention is a national VHA priority and mission. The most recent VHA campaign to prevent Veteran suicide was the executive order, President's Roadmap to Empower Veterans and End the National Tragedy of Suicide (PREVENTS), signed in March 2019 (National Veteran Suicide Prevention Annual Report, 2019).

For the Veteran Health Administration (VHA) the statistical data for Veteran suicide increased from $15.9 \%$ in 2005 to $16.8 \%$ in 2017 (National Veteran Suicide Prevention Annual Report, 2019). Among U.S. adults, the average number of suicides per day rose from 86.6 in 2005 to 124.4 in 2017 . These numbers included 15.9 Veteran suicides per day in 2005 and 16.8 in 2017. The suicide rate for Veterans, in 2017 was 1.5 times the rate for non-Veteran adults, after adjusting for population differences in age and sex (National Veteran Suicide Prevention Annual Report, 2019). The U.S. Department of Veterans Affairs (VA) National Strategy for Preventing Veteran Suicide: 2018-2028, is very clear in its mission. The VHA is treating suicide as a national public health tragedy that impacts not only Veterans but also people from all walks of life (Office of Mental Health and Suicide Prevention, 2018). The VHA has embraced a comprehensive public health model, that while remains evidenced based, it seeks to reach beyond the traditional medical model of prevention by ensuring interprofessional, family, and community active participation nationwide (Office of Mental Health and Suicide Prevention, 2018). 


\section{Framework and Change Theory}

The organization was assessed and deemed ready for practice change with leadership in full support. The theoretical framework that best fit this project was The Stevens' ACE STAR Model of Knowledge Transformation and it was selected as the framework due to its systematic integration of evidence into daily practice (Stevens, 2010) (see Figure 1). Stevens' ACE STAR model is comprised of five major stages for hastening healthcare improvements in science and is known as one of the most used frameworks to transform improvement science into safe patient clinical practice (Correa-de-Araujo, 2016). Stevens' theory is also considered a paradigm of continual monitoring of changes evidence-based practice has on patient care in order to evaluate its effectiveness at achieving the right patient outcomes (Bonis et al., 2007).

DMAIC is an acronym for a five-part process used to Define, Measure, Analyze, Improve, and Control improvement performance and is an approach of Lean Six Sigma (LSS). Its value in healthcare focuses on improving the patient experience by making sure that quality processes consistently deliver the desired positive patient outcome results. It also helps service providers to reduce waste and variation in the service processes (Ahmed, 2019) (See Figure 3). The DMAIC model was used to effectively implement a timeline to monitor and expedite the change project. DMAIC was used in the change project as a framework to improve existing programs or process.

The Stevens' Model and the DMAIC processes aligns well with the VHA's dedication to educational, teaching, and patient improvement outcome endeavors designed at achieving the highest level of quality healthcare and performance improvements. The organization, interprofessional team, and the Mental Health and Behavioral Sciences (MH\&BS) was assessed as ready for practice change. The VHA Hospital and MH\&BS leadership support was attained. 


\section{PICOT Question}

Do patients with an admitting diagnosis of suicidal ideation and a psychiatric inpatient introduction to Cognitive Behavioral Therapy-Suicide Prevention (CBT-SP) and who consequently after discharging self-elect outpatient CBT-SP treatment, reduce the likelihood of readmission for suicidal ideation vs. patients who decline CBT-SP treatment and elect Treatment as Usual (TAU) over a six-week period?

\section{Population}

The population included a convenience sample, from a large VA Hospital Emergency Department in the southeast, comprised of adult men and women, ages 18-90 years of age who are Veterans from all wars and experienced suicidal ideation and/or suicide attempts. These individuals had multiple mental health diagnoses and were admitted with suicide ideation and identified by a positive Columbia-Suicide Severity Rating Scale (C-SSRS).

\section{Intervention}

The project's change intervention was to roll-out CBT-SP within the outpatient department of the designated VA hospital. Multiple mental health professionals provided a CBTSP for 6-weeks. Patients who were interested and agreed to participate in CBT-SP and the change project were tracked and data analytics maintained.

\section{Comparison}

There was a comparison of patients between the CBT-SP and the TAU groups regarding hospital readmissions and a pre and post score comparison on the Quality of Life Scale (Burckhardt \& Anderson, 2003) (see Appendix A) for the CBT-SP group only. The demographic variables of age, sex, and homelessness was also compared to check for variability. 


\section{Outcome}

The outcomes measured were the rehospitalization rate and shifts in patient perception of Quality of Life. Any decrease in rehospitalization rate or improvement in Quality of Life denoted clinical significance. A $p<0.05$ is required for statistical significance.

\section{Timeline}

The DNP scholarly change project timeline was approximately 6-weeks of outpatient CBT-SP therapy. Once the University of St. Augustine and a large VA hospital in the southeast conducted and approved the EBP processes, implementation of the change project began (Larkin, 2019).

\section{Literature Search Strategy}

A literature review began with an electronic search of digital databases to include Cumulative Index to Nursing and Allied Health Literature (CINAHL), Medline, ProQuest, and PubMed. The headings and keywords for all searches comprised two main constructs: suicide prevention and CBT-SP, interprofessional collaboration [(interprofessional) AND collaboration)] and inpatient outcomes, outpatient [(patient outcomes) OR (health outcomes) OR (healthcare outcomes)]. Additionally, hand searches were conducted using the reference lists in several related articles. To all searches, general limiters included time frame within five years of current date, report-type (peer reviewed, and publication language English). The searches in CINAHL and Medline databases were limited to 2013 through the present. This search resulted in 199 citations as follows: CINAHL, 85 citations; Medline, 42 citations; Journal of Interprofessional Care (JIC) (1995 - 2013) AND (healthcare outcomes), 20 citations; JIC AND (patient outcomes), 46 citations; hand searches of reference lists, 6 citations. Titles and abstracts of the 199 articles were carefully reviewed for relevance according to the following inclusion 
criteria: (a) IPC or IPE intervention participants are healthcare professionals; (b) acute care setting; outpatient care settings and (c) reports objectively measured patient health-related outcome. Forty evidenced-based, peer reviewed research articles were obtained. The studies were randomized controlled trials (RCT), systematic reviews, meta-analysis, qualitative and quantitative and mixed methodology. The articles were reviewed for level and quality by using the Johns Hopkins Nursing Evidence-Based Practice Level and Quality Guide (Dearholt \& Dang, 2012). The articles included a combination of Level 1-3 and Grade High-Moderate. Exclusion criterion was student participation and age under 18.

\section{Literature Search Results and Evaluation}

The online search resulted in 106 citations from CINAHL, 21 citations from Medline, 193 citations from PubMed, and 53 citations from ProQuest. The total number of articles were reduced when duplicate articles were excluded. Inclusion criteria allowed (1) suicide and selfinjury; (2) suicide meta-analysis and meta-regression literature; (3) retrospective study of Root Cause Analysis literature; (4) allowance of various settings/environments outpatient mental health follow-up utilizing CBT-SP occurred. Exclusion criteria restricted database search to (1) adults 18 years and older; (2) peer-reviewed research and journal articles earlier than 2005 were restricted except for the two historical articles dated 2005. All other articles were 2014-present. Hence the relevant studies were narrowed to the 12 shown in the evidence table (see Figure 2).

The Johns Hopkins Nursing Evidence-Based Practice Rating Scale (Dearholt \& Dang, 2012) was used to determine the table of the evidence. There were 12 Randomized Controlled Trial (RCT) studies included in the search of the literature. Of the studies, six were single study RCTs, of which five were of level I quality and five were Grade A and the sixth was Grade B (see Table 1). The search of literature produced six systematic reviews, which were a level II and 
had an overall strength of evidence grade high to moderate. The overall strength of the aggregate evidence had a high to moderate grade (see Table 1). A summary of primary resources and systematic reviews included themes of the efficacy of CBT versus TAU, efficacy of CBT for suicide ideation and attempts, and CBT-SP in reducing suicide ideation and attempts with Veteran populations (see Table 1).

\section{Themes from the Evidence}

The primary themes found in the literature were compared with non-VHA and VHA national protocols, regulations, and directives. A summary of the thematic primary resources and systematic reviews summary is contained in Appendix B. The Johns Hopkins Evidence Level and Quality Guide was used to identify high-quality, evidence-based resources from peer reviewed journals. The literature included three themes: cognitive behavioral therapy versus treatment as usual, effectiveness of cognitive behavioral therapy in reducing suicidal ideation, and the effectiveness of cognitive behavioral therapy in reducing suicidal ideation in the veteran population.

\section{Cognitive Behavioral Therapy versus Treatment as Usual}

Cognitive Behavioral Therapy (CBT) versus Treatment as Usual (TAU) emerged from four studies; two primary RCT (Bryan et al., 2018; Haddock et al., 2016) and three systematic reviews, RCTs (Gotzsche \& Gotzsche, 2017; Watts et al., 2014; Witt et al., 2018). The three primary reviews were longitudinal RCTs, varying from six months and two years, in which all demonstrated CBT-SP versus Treatment as Usual (TAU) was superior (Brown et al., 2005; Bryan et al., 2018; Rudd et al., 2015). One systematic review demonstrated a 60\% decrease in suicide ideation (Bryan et al., 2018; Haddock et al., 2016). The strength of the three systematic studies was the adherence to the CONSORT principles. Another strength of these studies was 
that participants completed interview assessments at serial times post baseline by an independent evaluator who was blinded to the treatment conditions. The three systematic review studies were large reviews. One had 18 RCTs and the other 48 RCTs, and the last had 7 RCTs. Two studies had large sample participant numbers in the thousands which strengthened the studies. However, there was considerable variability amongst the studies. In all three systematic studies CBT was found to be significantly superior to TAU (Gotzsche \& Gotzsche, 2017; Watts et al., 2014; Witt et al., 2018). All studies are outlined in Appendix B. An overall weakness in the three systematic reviews was TAU was often operationally not well defined and this contributed to the limitation of many of the studies.

\section{Effectiveness of Cognitive Behavioral Therapy in Reducing Suicidal Ideation}

Effectiveness of Cognitive Behavioral Therapy in Reducing Suicidal Ideation emerged from two primary source studies, one RCT and one retrospective report review respectively (Brown et al., 2005; Riblet et al., 2017). The RCT was an 18-month longitudinal study and CBTSP proved more effective, but its weakness as compared to the Theme I longitudinal studies is that it did not have comparably large sample sizes. The retrospective report of root cause analysis (RCA) of deaths within seven days of discharge from an inpatient psychiatric hospital for suicide ideation or attempt was longitudinal, like those in Theme I, over an eight years' timeframe. There were five systematic reviews (Brown \& Jager-Hyman, 2014; Calati \& Courtet, 2016; Ghahramanlou-Holloway et al., 2015; Mewton \& Andrews, 2016; Tarrier et al., 2008). The five systematic reviews all had large RCT reviews ranging from 16 to 32 . One RCT systematic review had randomized patients greater than 4,000 in number (Calati \& Courtet, 2016). All reviews were successful in determining the effectiveness of CBT-SP versus TAU in reducing suicidal behaviors in adults. All five systematic reviews identified studies from PsycINFO, 
Cochrane Library and/or Web of Science databases. One systematic review cited the intervention of reducing suicide ideation and attempts by introducing CBT-SP while patients are on the acute in-patient psychiatric units (Ghahramanlou-Holloway et al., 2015). The strength of all five systematic reviews was each had serial monitoring of the effectiveness of CBT-SP. Sources are depicted in Appendix B. Unfortunately, all five had enormous variability across the studies in both method and treatment techniques, which was considered a limitation.

\section{Effectiveness of Cognitive Behavioral Therapy in Reducing Suicidal Ideation in the}

\section{Veteran Population}

Effectiveness of Cognitive Behavioral Therapy in Reducing Suicidal Ideation in the Veteran Population was developed from three primary source studies (Brown et al., 2016; Bryan, Rozek et al., 2019; Rudd et al., 2015). The evidence search bore an RCT evaluating the effects of CBT-SP versus TAU in a longitudinal study with two-year follow-up (Rudd et al., 2015). One study was of a Veteran Training Program with a sample size of 900 plus Veterans evaluating the effectiveness of CBT for depression and suicide (Brown et al., 2016) and lastly there was a study evaluating the patterns of change and fluid vulnerability of suicide ideation in high-risk suicidal military soldiers (Bryan et al., 2019). The three studies had results that indicated CBT-SP and depression treatment was effective in reducing suicide ideation and re-attempt episodes. One study cited the odds of suicide re-attempts decreased by $64 \%$ at final assessment (Brown et al., 2016) (see Appendix B).

\section{Practice Recommendations}

A methodical review of the literature answered the PICOT question by establishing that the implementation of Cognitive Behavioral Therapy-Suicide Prevention (CBT-SP) was effective for reducing the likelihood of readmission for suicidal ideation versus patients who 
decline CBT-SP treatment and elect Treatment as Usual (TAU). The Johns Hopkins Nursing Evidence-Based Practice Level and Quality Guide was used to verify the quality and level of evidence-based literature (Dearholt, \& Dang, 2012). The strength of the literature substantiated the practice change recommendation. A synthesis of evidence found in the literature revealed the conclusion that implementation of the intervention of CBT-SP reduced hospital re-admission for suicide ideation and/or suicide attempts.

Most of the primary studies utilized a measurement tool. The Beck Depression InventoryII (BDI-II), was a common tool used and has high validity and reliability. The BDI-II has a reliability range of 0.73 to 0.96 and validity showed good sensitivity and specificity in the detection of depression (Wang \& Gorenstein, 2013). The Hamilton Rating Scale for Depression (HRSD) was another common tool used and has a test-retest reliability rage of 0.65 to 0.98 (Trajkovic et al., 2011). The primary studies also utilized other quality of life assessment tools.

The integrity of the research design was addressed in all the research studies. Three of the RCT primary studies were longitudinal in design with high sample size, Level 1, and Grade A. The Brown et al., (2005) 18-month longitudinal study for example found that patients that presented to the hospital following a suicide attempt and who received CBT-SP were 50\% less likely to reattempt suicide during the follow-up period than those in the TAU group. The Rudd et al., (2015) two-year longitudinal study showed military personnel who were in the CBT-SP were $60 \%$ less likely to attempt suicide than those who were TAU. The primary studies had variability pertaining to the Clinical Trial Assessment Measure (CTAM) [sample size and recruitment method, assignment to treatment, assessment of outcome, control group, description of treatment and statistical analyses] (Lobban et al., 2013), but overall found in favor of CBT-SP as opposed to TAU. 
The systematic reviews adhered to the CONSORT principles in choosing the studies for review inclusion. There are six of the eight systematic reviews from the Cochrane Library database for a total of 183 RCTs with a Grade of High to Moderate. Although there were a few mixed findings and some limitations within the selected RCTs; overall, there is moderate to high evidence that CBT-SP based interventions focused on suicide prevention are effective at reducing repeat suicide occurrences. These findings align with the VA/DoD Clinical Practice Guideline (CPG) for the Assessment and Management of Patients at Risk for Suicide (2019). The CPG reviewed eleven studies of which eight were primary sources and three systematic reviews. This DNP scholarly review has four of the eleven CPG studies, one of which is a systematic review (Gotzsche \& Gotzsche, 2017) and three primary sources (Brown et al., 2005; Riblet et al., 2017; Rudd et al., 2015). The strength of the overall evidence supports the implementation of CBT-SP as an effective intervention for the reduction of suicide ideation and reattempts. CBT-SP is considered a strong recommendation by the CPG with little to no risk to patient well-being. Cognitive Behavioral Therapy-Suicide Prevention (CBT-SP) is effective for reducing the likelihood of readmission for suicidal ideation versus patients who decline CBT-SP treatment and elect Treatment as Usual (TAU).

\section{Project Setting}

The location for this DNP scholarly project was the mental health out-patient clinic setting of a large adult tertiary care level-1 415 bed hospital on the southwest coast of Florida, which is part of a much larger VHA organization. The facility provides Veteran care for primary care, tertiary care, and long-term care in areas of medicine, surgery, psychiatry, physical medicine and rehabilitation, spinal cord injury, neurology, oncology, dentistry, geriatrics, and extended care (James A. Haley VA Hospital \& Clinics [JAHVAHC], personal communication, 
June 26, 2019). The mission and vision of the VA is to fulfill President Lincoln's promise "To care for him who shall have borne the battle, and for his widow, and his orphan" by honoring the men and women who are America's Veterans (U.S. Department of Veterans Affairs, 2015). Details regarding the organizational structure, culture, needs assessment, stakeholders, project support and sustainability, interprofessional collaboration, and a SWOT analysis were discussed below (see Appendix C).

\section{Organizational Structure}

The project setting was a large VHA health care network. The care model includes multiple health care settings, including acute care, urgent care, community-based out-patient clinics (CBOCs), specialty care, and long-term care nursing centers. The business model is a notfor-profit quality healthcare organization. The organizational structure included a Pentad consisting of a Director, which is the equivalent of a CEO, a Deputy Director the equivalent of a COO, Chief of Staff, equivalent of Chief Medical Director and Associate Director of Patient Care, equivalent of Chief Nursing Officer. The next level includes Chiefs, Service Chiefs, Supervisors, Managers and Assistant Managers. Direct care staff report to Assistant Managers and Managers.

\section{Organizational Culture}

The VHA organization is a culture of diversity and inclusion both with patients and staff. The patient culture is patient-centered with an overlay of a military culture that is on the journey of becoming a High Reliability Organization (HRO). VHA nurses becomes adept in recognizing symptoms and sequelae of posttraumatic stress disorder, traumatic brain injury, and military sexual trauma that lead to suicide ideation and suicide attempts. There are increased risks among 
veterans for suicidality and substance abuse, and nurses are taught to screen accordingly.

\section{Organizational Need}

An organizational needs assessment was completed. Variable cost per bed per day of care for inpatient psychiatry is approximately $\$ 1,242.00$ and the length of stay is approximately five to seven days, providing there is no other psychiatric co-morbidity (B. Konkel, personal communication, January 20, 2020; W. Levy, personal communication, January 25, 2020). A review of the group programming in the out-patient psychiatric setting revealed that while Cognitive Behavioral Therapy (CBT) was being conducted there was no specific group that addressed CBT for suicidal ideation. Psychiatric leadership then gave the approval and support needed to conduct this DNP scholarly project utilizing CBT-SP.

\section{Organizational Support}

The Chief of Psychiatry was the first administrator to provide support for this DNP scholarly project and encouraged other staff members to lend their support. The physician Suicide Prevention Coordinator and psychologist Suicide Prevention Team Leader also had been a tremendous support in providing information and guidance on this project. The in-patient psychiatrists as well as the two DNP preceptors were extremely implemental in working on this change project.

\section{Stakeholders}

Brainstorming was the tool used to identify those individuals whose interests are affected by the DNP scholarly project of CBT-SP. A simple three column chart was used to brainstorm to identify the criteria needed to determine the appropriate stakeholders (see Appendix D). While the Input, Tools \& Techniques, and Output were used to brainstorm, the initial stakeholders were identified as the Chief of Psychiatry, psychiatrist, psychologist, admitting emergency department 
psychiatrist, nursing service, social work service, two DNP preceptors, and a data/IT. It was critical for the success of the project to have key stakeholders.

\section{Sustainability}

Sustainability is the successful outcome of process and practice improvements over time. In a High Reliability Organization (HRO), a culture of safety is critical for sustainability (Agency for Healthcare Research and Quality, 2019). The VHA is on the journey of becoming an HRO. VHA is a highly complex healthcare system and culture change can be difficult. Yet, based on the fluidity of healthcare, changes must be made. Shifting to the culture of HRO can assist all staff with accepting and adapting to continuous change. The first pillar is leadership commitment, which provides facility leaders and frontline staff the education regarding the importance of leadership support (Andriulo et al., 2015). Essentially, an organizational change that incorporates safety and resilience will be reflected in the vision, mission, and actions of leadership. The second pillar is the implementation of a safety culture. According to Sullivan (2019), implementing a culture of safety will encourage all employees in the organization to implement safety values and practices to assist with the prevention of harm to patients. A culture of safety, that is just, also allows organizational employees the ability to learn from errors to continuously make process improvement, which is the third pillar (Andriulo et al., 2015). The continuous process improvement pillar recommends the development of various improvement teams across the organization. The Department of Veteran Affairs has websites, SharePoints and lists of providers currently trained in CBT and other evidence-based practice modalities (James A. Haley VA Hospital \& Clinics [JAHVAHC], personal communication, June 26, 2019).

\section{Interprofessional Collaboration}

Interprofessional collaboration is fundamentally necessary. Interprofessional teams or multidisciplinary teams are not new to the VHA (VHA Locations, n.d.). The Interprofessional 
Professionalism Assessment (IPA) tool is a five principle, 26 item "observational rating tool used by faculty/preceptors to assess learners' professionalism when working with members of other health professions" (National Center for Interprofessional Practice and Education, 2018). There are five principles of the IPA that resonate as extremely important to interprofessional teamwork: 1) Communication, 2) Respect, 3) Altruism and Caring, 4) Excellence, and 5) Ethics. Psychometric properties were tested with 10 health professions to determine its reliability and validity across multiple health care professions (National Center for Interprofessional Practice and Education, 2018). Patients were identified as suicidal on the inpatient psychiatric unit by nursing/data team member. Education on the benefits of CBT-SP was offered to patients at discharge by the DNP student and/or psychologist. Those accepting outpatient 6-week CBT-SP therapy was followed as well as the TAU group by the interprofessional team.

\section{Strengths, Weaknesses, Opportunities and Threat Analysis (SWOT)}

The SWOT analysis identified that the organization has competitive strengths with their organization's core values and mission directives towards quality care (see Appendix C).

Weaknesses stem from external directives from Congress through national mandates that are not quality or evidence based. Opportunities for evidence-based clinical practice are supported and readily available to staff that are willing to take the initiative. Threats to clinical practice are very real and not easily remedied. Pay scales are dictated externally by the VISN. They are reviewed every two years and are very resistant to increases in comparison to the private sector. The Office of the Director is not supportive of flexible shifts. These are threats to maintaining the quality of our clinical practice. The organization has strengths, weaknesses, opportunities, and threats. Overall, they are aimed at quality care and evidence-based clinical practice and remain a desired organization to work for. 


\section{Project Vision, Mission, and Objectives}

\section{Project Vision and Mission}

To provide veterans the world-class benefits and services they have earned and to do so by adhering to the highest standards of compassion, commitment, excellence, professionalism, integrity, accountability, and stewardship (James A. Haley VA Hospital \& Clinics [JAHVAHC], personal communication, June 26,2019$)$. The vision of this project was to fully implement a CBT-SP 6-week outpatient program to reduce suicide attempts and suicide ideation by decreasing hospital admissions related to suicide. The project mission was the integration of CBT-SP, a theoretically grounded evidence-based practice principles of psychological therapy aimed to understand problems associated with the relationship between thoughts, physiological sensations, emotions, and behaviors (Bryan et al., 2018). The mission of the project aligns with VHAs mission of providing the highest standard of quality care to our Nation's Veterans.

\section{Project Objectives}

The U.S. Department of Veterans Affairs (VHA) National Strategy for Preventing Veteran Suicide: 2018-2028, is very clear in its mission of treating suicide as a national public health tragedy that impacts not only Veterans but also people from all walks of life. The objective of this project was to implement a 6-week therapy for prompt CBT-SP. Patients were identified on the inpatient psychiatric unit and offered outpatient CBT-SP therapy at discharge. Early intervention of CBT-SP may reduce or prevent reattempts of suicide, both while inpatient and outpatient.

\section{Short-Term Goals}

A short-term goal of CBT-SP was identified and immediately assessed to provide suicide prevention therapy for newly discharged patients diagnosed with suicide ideation. Continuum of 
care from acute inpatient psychiatry to instant outpatient follow-up. The expected outcome of decrease suicide rates with active participation in outpatient CBT-SP should be evident within 6 weeks of treatment (Mewton et al., 2014).

\section{Long-term Goals}

Long term goal would be the culmination of the DNP scholarly change project with every aspect of the project process emphasizing the strength and recommendation of the project

(Green, 2019). The expectation was the data results from this EBP project would fully support a practice change in the dissemination and spread of CBT-SP. The CBT-SP begins with identification on the inpatient psychiatric unit and continues with a 6-week outpatient CBT-SP therapy to optimize reduction in reattempts of suicide. Optimal long-term would be permanent incorporation of CBT-SP in the Mental Health \& Behavioral Sciences Service.

\section{Untended Consequences and Risks factors}

Ethical aspects of implementing CBT-SP would pose little to no adverse impact to patients who currently receive some form of acute inpatient stabilization for SI and minimally TAU as an outpatient. This was an evidence-based project collecting and analyzing quantitative and qualitative data on the effectiveness of CBT-SP. VHA is a teaching organization and routinely conducts research and EBP projects and is familiar with protected health information (PHI). The EBP process was completely reviewed and sanctioned this project prior to implementation. All patients self-elected to participate in the project. Patient information was secured by password and Personal Identification Verification (PIV) card encryption as PHI controls on the Department of Veterans Affairs Computerized Patient Record System (CPRS) sites. Confidentiality was maintained by alerts that state restrictions apply, and access tracking is 
monitored (James A. Haley VA Hospital \& Clinics [JAHVAHC], personal communication, June 26, 2019).

\section{Project Plan}

The Stevens' ACE STAR Model of Knowledge Transformation (2004) provided the framework and change model that served as the frame of reference for this DNP scholarly change project. It is a five-stage framework for knowledge transformation to integrate evidence into practice (see Figure 1). The five-stage framework in Stevens' ACE STAR Model include (1) discovery of CBT-SP knowledge and efficacy in treating suicidal behavior, (2) evidence of RCT research studies and systematic reviews with synthesis of literature summary, (3) translation into guidelines, with the aid of VHA CPG, for suicide prevention to implement evidence-based practice into action, (4) practice integration would incorporate CBT-SP into the Mental Health \& Behavioral Sciences Service program showcasing CBT-SP aligns with the service's best practices for healthcare, (5) process, outcome, evaluation would illuminate the impact and strong recommendation for CBT-SP vs. TAU as the most operative in decreasing suicide ideation and suicide attempts. The DMAIC model was incorporated with Stevens' ACE STAR Model of Knowledge Transformation to effectively implement a timeline to monitor and expedite the change project. DMAIC was used in the change project as a framework to improve existing programs or process.

\section{Evaluation of CBT-SP Integration with Existing Programs}

Stevens' model was chosen for this project because it effectively and efficiently analyses positive CBT-SP interventions into clinical knowledge and practice (Stevens, 2011). New knowledge derived from CBT-SP and the Stevens ACE STAR Model must then be transformed into clinically useful protocols and evidence-based practice (Stevens, 2013). Lastly there was 
effective implementation across the entire interprofessional care team within a systems context (Stevens, 2013). By utilizing CBT-SP CPG, mental health providers were able to transform healthcare from a systems perspective, focus on EBP for clinical effectiveness and efficacy (Stevens, 2013). Ultimately, CBT-SP increased patient engagement, and patient survival outcomes.

\section{Impact on Suicide Attempt Rates and Hospital Readmission for Suicide}

The providers used cognitive restructuring strategies such as identifying and evaluating automatic thoughts from cognitive therapy (Brown \& Jager-Hyman, 2014). TAU did not include CBT-SP but can include one or more of the following: multidisciplinary therapy, psychotherapy only, pharmacotherapy only, treatment by primary care provider, or minimal to no follow-up (Witt et al., 2018). It is only through enhancement of coping skills and reduction of isolation by providing support and stressing the importance of adherence to mental health and/or substance abuse disorder treatment, can the ultimate goal of reduced suicide attempts be met

(Ghahramanlou-Holloway et al., 2015).

\section{Create a Coalition}

All efforts from key stakeholders were positive, enthusiastic, and marked with extreme support for the success of this EBP project. The two DNP preceptors were always available and receptive to endeavors to create a thorough and comprehensive project. The Chief of Psychiatry, nursing leadership, psychiatrists and psychologists all provided a leadership presence, provision, and accountability. There was a data mental health clinician and the project manager who identified and tracked the patients who elected CBT-SP and those who elected TAU. One DNP preceptor was on the inpatient psychiatric unit as a full-time employee and was able to monitor data collection, PHI, completion of C-SSRS and assist with education on CBT-SP using 
brochures designed for this educational purpose. Control of performance measures were frequently monitored to ensure reliability and validity and were controlled for risks, delays, and need for change adjustments (Sasal, 2018).

\section{Develop a Project Vision}

The Mental Health \& Behavioral Sciences Service Chief of Psychiatry had concerns about implementing a practice, possibly program, and its sustainability after the DNP scholarly change project ends. According to Mewton \& Andrews (2016), suicide prevention, both inpatient identification and outpatient interventions, is everyone's responsibility and there is indication that global suicide rates are decreasing due to the impact of suicide prevention strategies. The interview with Mental Health Leadership identified their concerns of lack of follow-up after hospital discharge with a diagnosis of suicide ideation with mental health outpatient CBT-SP providers. According to Kogon et al. (2015), maintaining shared vision is essential and instrumental to a successful project. Discharge follow-up appointments were made prior to the patient leaving the inpatient psychiatric unit. The challenge that this EBP project faced involved ensuring immediate buy-in by the patient for CBT-SP therapy, patient engagement for the 6week duration, and constant staff encouragement to adhere to the project vision (Kogon et al., 2015).

\section{Communicate and Constantly Reiterate Project Vision}

Attrition in drop-out rate was a potentially high factor with this population of patients. The interprofessional team had a goal of admitting all suicidal participants in the DNP scholarly change project in order to obtain a sample size. CPRS was used following each weekly meeting and monitoring was done according to the Gantt Timeline (see Appendix E) to make appropriate project manager corrections needed to stay on course (Kogon et al., 2015). DMAIC, Stevens' 
ACE STAR Model for Knowledge Transformation, VHA CPG, Gantt Timeline and the Metric Metrix were all used to monitor project timeline, encourage staff continued engagement, update hospital and mental health leadership. Small wins were frequently discussed and shared with all interprofessional team members and leadership (Kogon et al., 2015).

\section{Barriers and Obstacle Removal While Empowering Facilitators}

A healthcare failure mode effective analysis (HFMEA) was conducted to identify patients with suicide ideation early in the emergency department to inpatient psychiatry admission process. The HFMEA was also utilized to identify and mitigate obstacles determined by the interprofessional team (Kogan et al., 2015). The DMAIC Model was used to improve project dissemination processes and begin sustainment of improvement efforts (Kumar \& McKewen, 2011).

\section{Project Schedule}

The Gantt Timeline Chart and the Metric Matrix detailed a schedule of activities and check points used to monitor EBP project progress as indicated in the project manager timeline (see Appendix E and F). Data collection occurred as stated on the Gantt Timeline Chart and Metric Matrix. Data were analyzed at the end of the 6-week CBT-SP intervention. Continuous staff education and checks for competency, pre/post-test, documented patient instruction and education on CBT-SP, documented descriptive data from the Columbia-Suicide Severity Rating Scale (C-SSRS) assessment of severity of suicide ideation, indication CPG and hospital policy were followed, and audits of all data were collected.

\section{Resources and Budget}

The interprofessional team were the most valuable resource to this DNP Scholarly change project and its success. There would be no cost to the patients as CBT-SP was in addition to 
services provided by Mental Health \& Behavioral Health Science Services. Educational costs for one hour of training for eight staff was provided and included in the budget. There were two DNP preceptors (average salary of $\$ 54$ per hour), three psychologists ( $\$ 100$ per hour), four mental health counselors ( $\$ 40$ per hour), two data/IT technologist support (\$25 per hour), and two nursing staff at \$40 per hour. Additional organizational costs included educational materials/manual, educational pamphlets for patients and sundry $(\$ 300)$. Total project cost was approximately $\$ 998$. A detailed budget breakdown is provided on the Budget Table (See Table 2).

\section{Project Management Role and Leadership Skills.}

According to Kogan et al. (2015), operative leadership skills and the ability to differentiate between optimal management to effect project management change begins with learned skills. Project management and leadership skills are very similar in both have input, tools $\&$ technology and outcome requirements to a consumer or patient (Kogan et al., 2015). There are deadlines, deliverables, patient care services, and patient outcomes that must be met. Managing this project required flexibility, strong leadership aids and resources, organization, and excellent communication skills (Kogan et al., 2015). This project required attention to detail and strict supervision of timelines and due dates.

\section{Evaluation Plan}

The Steven's ACE STAR Model and the DMAIC model guided the project evaluation. The plan evaluated whether the implementation of CBT-SP therapy would decrease the number of readmissions of patients to an inpatient psychiatric unit for suicidal ideation, as compared to those patients who elected treatment as usual (TAU) for a 6-week time frame (Posner et al., 2014). Participant selection included a convenience sample based on self-selection. Both 
parametric and non-parametric statistical analysis methods were used to compare intervention variables. Secured, public health information (PHI) data collection tools were used to gather intervention data for comparison and statistical analysis testing as discussed below.

Participant selection and methodology involved CBT-SP success rate data and education, provided by a mental health licensed (MHL) provider and psychiatric nurses, to inpatient psychiatric patients who had a diagnosis of suicide ideation or attempts. Patients who elected CBT-SP and TAU were monitored for 6-weeks and the data were collected. The patient identification system included the last four from the social security number for tacking and monitoring for readmissions, for both groups, to inpatient psychiatry for suicide attempts and ideation. The tracking and monitoring system were inclusive of the principle VA hospital and any other community hospital within the region. Attrition of those no longer participating in either of the two groups (CBT-SP vs. TAU) was also monitored throughout the 6-week period by weekly audits for exclusion from the project.

Missing data were mitigated by use of electronic hospital record (EHR) that listed patients admitted every day with a diagnosis to one unit that treats psychiatric patients. The MHL provider, two DNP preceptors and the DNP project manager had full access to all inpatient psychiatric patient data. When the MHL provider was not available, the psychiatrist offered CBT-SP to the patient, at the time the last negative C-SSRS was completed at time of discharge. All patients who screened positive on the C-SSRS and were admitted to the inpatient psychiatric unit and then subsequently discharged with a negative C-SSRS screen and chose to either enroll in the CBT-SP therapy or TAU for a completion of the 6-week period were included in the project. Primary data from the Quality of Life tool was collected from the CBT-SP patients 
themselves. The completion of both CBT-SP and TAU demographic and rehospitalization data were the secondary data extracted from a retrospective EHR review.

Upon discharge those patients who choose the CBT-SP therapy were surveyed with the Quality of Life Scale at week one and then again at week 6 to ascertain if there was a difference in their perceived satisfaction. Both groups then either received CBT-SP or TAU for a 6-week timeframe. At treatment conclusion, a chart audit was conducted to compare the number of hospital readmissions between the two groups CBT-SP and TAU for suicidal ideation or attempts. Patients who initially agreed to attend the CBT-SP group, but did not participate in the group were considered in the attrition rate and not part of the EBP project

\section{Formative Evaluation}

Formative evaluations were used to ensure that the project was progressing as scheduled and to determine if any changes were needed to improve the project. This process aligns with the DMAIC cycles for identifying opportunities to improve the project before initiating the next cycle. The C-SSRS tool was used to identify patients with suicidal ideation or attempts in the Emergency Department of the designated tertiary hospital. This tool is the screening tool of choice within the department and is an eight-item nominal yes/no question scale that screens for suicidal thoughts and behaviors over the past month to the past three months. If questions three, four, five, or eight are answered in the affirmative the screen is considered positive and the clinician would then proceed to conduct a comprehensive suicide assessment. However, the CSSRS tool is used as a diagnostic tool by the tertiary hospital during normal operations and was collected for this project. Only those patients that screen positive on C-SSRS were included in the project. 
The C-SSRS was developed by a team of investigators from Columbia University, the University of Pennsylvania, and the University of Pittsburgh (Posner et al., 2014). The C-SSRS is used to complete suicide risk assessments on all patients diagnosed with suicide ideation in the VHA (C-SSRS, 2019). The C-SSRS is a highly predictive measure of content and construct validity and reliability (see Appendix G). The C-SSRS has a reliability rate of .88 or higher and a high predictive validity rate due to its high reliability (C-SSRS, 2019). The C-SSRS is completed on ALL patients with admission diagnosis of suicidal ideation and at hospital discharge. At discharge, the C-SSRS MUST be negative or discharge does not occur without additional length of stay and interventions. Data were captured and collected, at week one and at end of therapy week 6 of the CBT-SP intervention group, via a Quality of Life Scale (see Appendix A). Data review and examination of variables were intently scrutinized to determine if CBT-SP was the actual intervention that affected change: 1) therapy/group attendance; 2) readmission rates for suicide ideation or suicide attempts to inpatient psychiatry; and 3) Quality of Life Scale (Burckhardt \& Anderson, 2003).

\section{Summative Evaluations}

The Quality of Life (QOL) scale is a 16-item ordinal Likert scale with five domains of quality of life (material and physical well-being, relationships with other people, social, community, and civic activities, personal development and fulfillment, and recreation). The QOL scale ranges from one through seven, with one being terrible and seven being delighted on the aforementioned domains. The goal was for the C-SSRS nominal scale to remain negative and Quality of Life score to increase.

\section{Variables and Other Measures}


The independent variable in this project was the implementation of the CBT-SP therapy. One related dependent variable was the number of patients who experienced CBT-SP therapy and were readmitted for suicide ideation or attempt post CBT-SP therapy. Another dependent variable is the number of patients who underwent CBT-SP therapy and experienced a perceived increase in satisfaction on the Quality of Life Scale (see Appendix A). The Matrix Metric (see Appendix F) outlined the outcomes, processes, balancing, financial, and sustainability factors. There are no benchmarks for these measures.

\section{Protection of Human Rights and Privacy}

Ethical aspects of implementing CBT-SP posed little to no adverse impact to patients who currently receive some form of acute inpatient stabilization for SI and minimally TAU as an outpatient. This was an evidence-based project collecting and analyzing quantitative and qualitative data and not a research study and as such had little impact or adversely impacted those patients receiving TAU. VHA is a teaching organization and routinely conducts research and is familiar with Protected Health Information (PHI). The EBP process completely reviewed and sanctioned this project prior to implementation. All patients did consent for participation in the project. Patient information and data were secured by password and personal identification verification (PIV) card encryption as PHI controls on the Department of Veterans Affairs Computerized Patient Record System (CPRS) sites. Confidentiality was maintained by alerts that state restrictions apply, and access tracking was monitored (James A. Haley VA Hospital \& Clinics [JAHVAHC], personal communication, June 26, 2019).

The data were collected by several project therapists and the data were transferred to the project manager via encrypted e-mail. The project manager then encoded the data within an Excel data base, which was stored and protected by use of a PIV card. The Quality of Life Scale 
was a hard copy and maintained in a locked, secure cabinet. Hard copy data were stored in a locked desk drawer in a locked office. Electronic data were stored in an Excel file on CPRS site with a strong password protection. Data were stored in a locked desk drawer and password protected Excel document and upon completion of the DNP degree the data were destroyed beyond reclamation.

In the interest of the EBP project integrity and patient safety the project manager submitted a DNP Scholarly Project Proposal Application for review by USAHS Nursing Evidence-Based Practice Project Review Council (EPRC) and the organization site Institutional Review Board/Evidence-Based Practice (IRB/EBP) review committee. The EBP project was approved by both entities without amendments.

\section{Results}

\section{Data Analysis}

The IBM SPSS program analysis was utilized to analyze the data. Data were entered into the IBM SPSS system and checked for accuracy before calculating results using a standard 0.05 p-value for significance at $95 \%$ confidence level for both the non-parametric and parametric data. The eventual group compositions of both groups generated 14 members in the CBT-SP group and 22 members within the TAU group. However, two members within the TAU group went to residential treatment centers post discharge and were excluded from the project because the re-hospitalization data from this group would have been inaccurate. Hence, the total number of participants from the TAU group was 20 for a total of 34 participants combining both the CBT-SP and TAU groups. Variable and measures of demographic data (see Table 3) was collected on both the CBT-SP implementation group and the TAU group and used to compare both groups based on age, sex, and homelessness, since these demographics have a correlation 
with suicidal ideation (Huang et al., 2017). The was no missing data and the data were checked several times by the project manager and the DNP preceptor for accuracy.

The ratio variable on age between the CBT and the TAU groups was analyzed using a two tailed t-test for unequal variance. The results indicated that there was a significant difference between the two groups regarding age with the CBT group mean age being approximately ten years younger than the TAU group, with the $\mathrm{p}<0.03$ (see Table 4). This was a surprise finding and will be discussed in the Discussion and Implication section.

\section{Table 4}

The Difference in Age Between the CBT and TAU Groups

\begin{tabular}{lrr}
\hline & Variable 1 & Variable 2 \\
\hline Mean & 40.35714286 & 52.85 \\
Variance & 229.3241758 & 250.7657895 \\
Observations & 14 & 20 \\
Hypothesized Mean & & \\
Difference & 0 & \\
df & 29 & \\
t Stat & -2.323128505 & \\
P $(T<=t)$ one-tail & 0.01369471 & \\
t Critical one-tail & 1.699127027 & \\
P $(T<=t)$ two-tail & 0.02738942 & \\
t Critical two-tail & 2.045229642 & \\
\hline
\end{tabular}

Note: t-Test: Two-Sample Assuming Unequal Variances. The t-value is -2.32312. The p-value is 0.0277389 . The result is significant at $\mathrm{p}<0.05$.

The nominal variable on sex between the CBT and the TAU groups was compared using the non-parametric Fisher exact test and results indicated that there was no statistical significance between the groups in terms of sex with $\mathrm{p}>0.68$ (see Table 5). 


\section{Table 5}

The Differences between the CBT and The TAU Groups on the demographic of Sex

\begin{tabular}{lccc}
\hline & Category 1 Male & Category 2 Female & Marginal Row Totals \\
Group 1CBT & 10 & 4 & 14 \\
Group 2TAU & 16 & 4 & 20 \\
Marginal Column & 26 & 8 & 34 (Grand Total) \\
Totals & & & \\
\hline
\end{tabular}

Note: The Fisher exact test statistic value is 0.6892 . The result is not significant at $\mathrm{p}<0.05$.

Homelessness was the third demographic variable explored and no statistical computation was necessary between both groups (CBT and TAU) because there were no homeless patients in either groups, hence no difference.

The difference between re-hospitalization within both groups was explored next. Due to an intervention truncated timeframe because of the COVID-19 virus, the amount of rehospitalizations may have been minimized (i.e., decreased re-admissions), thereby necessitating the use of a non-parametric statistic as opposed to a parametric test. There were no rehospitalizations within the CBT group and in order to determine if the six re-hospitalizations within the TAU group had any statistical significance it was necessary to treat the data as nominal (yes/no) in nature. A Fisher exact test was then used to analyze the data and the results were significant for TAU re-hospitalization with $\mathrm{p}<0.03$ (see Table 6).

\section{Table 6}

Comparison between the CBT and TAU Groups on Re-Hospitalizations

\begin{tabular}{lccc}
\hline & Category 1 No Re-Hosp & Category 2 Re-Hosp & Marginal Row Totals \\
Group 1 CBT-SP & 14 & 0 & 14 \\
Group 2 TAU & 14 & 6 & 20 \\
$\begin{array}{l}\text { Marginal Column } \\
\text { Totals }\end{array}$ & 28 & 6 & 34 (Grand Total) \\
\hline
\end{tabular}

Note: The Fisher exact test statistic value is 0.0311 . The result is significant at $\mathrm{p}<0.05$. 
Even without the non-parametric Fisher exact test the percentage of re-hospitalizations within the TAU group was $30 \%$ and this in itself lends clinical significance to the fact that no patient within the CBT-SP group experienced a hospital re-admission due to suicidal ideation or suicidal attempt.

The Quality of Life (QOL) Scale survey (ordinal data) was administered to the CBT-SP participants at week one and again at week six (see Appendix A). The Wilcoxon Signed Rank Test was used to analyze the QOL scores. The results indicated that the Wilcoxon Signed Rank Test result was significant at Z-value: -2.8563, Mean (W): 52.5, Standard Deviation (W): 15.93, with $\mathrm{p}<0.00424$ (see Table 7).

\section{Table 7}

Pre and Post Patient Quality of Life Scale Survey

\begin{tabular}{cccc}
\hline Sign & ABS & R & Sign R \\
\hline-1 & 33 & 14 & -14 \\
-1 & 23 & 11.5 & -11.5 \\
1 & 5 & 1.5 & 1.5 \\
-1 & 9 & 3 & -3 \\
-1 & 20 & 9 & -9 \\
-1 & 23 & 11.5 & -11.5 \\
-1 & 23 & 11.5 & -11.5 \\
-1 & 23 & 11.5 & -11.5 \\
-1 & 17 & 6 & -6 \\
1 & 14.5 & 4 & 4 \\
1 & 5 & 1.5 & 1.5 \\
-1 & 18 & 7.5 & -7.5 \\
-1 & 18 & 7.5 & -7.5 \\
-1 & 15 & 5 & -5 \\
\hline
\end{tabular}

Note: Z-value: -2.8563 , Mean (W): 52.5, Standard Deviation (W): 15.93, $\mathrm{p}<0.00424$

Sample size $(\mathrm{N}): 14$

\section{Impact}

The clinical finding from this EBP project was that patients with an admitting diagnosis of suicidal ideation that elected CBT-SP vs. TAU did not have a rehospitalization during the 6- 
week period of the CBT-SP treatment. The project outcome is comparable to outcomes identified in the literature that demonstrated the use of CBT-SP reduced the number of rehospitalization admissions (Brown et al., 2016; Bryan et al., 2019; Rudd et al., 2015). Clinical significance was apparent in that of the 14 patients who received CBT-SP, none of them had a readmission to the hospital for suicide ideation or suicide attempts as opposed to six (30\%) of the TAU patients who did. The use of CBT-SP in the outpatient setting has the possibility of effectively reducing the number of hospital re-admissions for suicide ideation or suicide attempts. The use of CBT-SP as an intervention to reduce suicide ideation and suicide attempts could facilitate a dramatic decrease in the overall rate of Veteran suicide. A decrease in hospital readmissions would decrease the financial burden on both the public and private funding resources (Bryan \& Rudd, 2019).

Similarly, the Quality of Life Scale pre/post patient self-reported survey demonstrated a significant increase in quality of life satisfaction. This speaks to the impact of CBT-SP in improving an individual's life skills in coping with everyday life demands. This increased resilience helps to mitigate suicide ideation and suicide attempts (Ahmadizadeh et al., 2013; Cajanding, 2016). The seven mental health therapists reported that the patients enjoyed the structure of the CBT-SP modality, thereby increasing patient attendance and participation. This in turn sparked an interest by the therapists to inquire of the project manager how the EBP project could become a sustainable practice change. Plans are now underway to provide CBT-SP training to the entire Suicide Prevention Team at the VA EBP project site.

Limitations of this EBP project included a small sample population of participants. This was due to the COVID19 pandemic necessitating a truncated timeframe for the project, shortening the CBT-SP timeframe from the original 12 weeks to 6 weeks. However, literature 
does support the effectiveness of a brief CBT-SP (i.e. 6 weeks) (Bryan et al., 2018; Rudd et al., 2015). This population was also clinically stabilized by not being homeless. It remains to be seen if the CBT-SP would be as effective with a more destabilized or homeless population.

The demographics of age, sex, and homelessness were explored because of their correlation to suicide ideation and suicide attempts (Huang et al., 2017). While the demographics of sex and homelessness were found to have no statistical significance differences between the two groups, the variable of age did have a significant statistical finding. The TAU group was approximately ten years older that the CBT-SP group. It is speculated that the TAU group knowing that the CBT-SP modality would only be offered via telemental health, as a result of COVID19, and not face-to-face individual or group meeting were disinclined to participate. It could be further speculated that the TAU group did not have or lacked the electronic items or skills to participate in telemental health. The implication to further improve the EBP would be to look to the literature on telemental health, age, and access.

Suggestions for sustaining this EBP project includes training as many mental health practitioners in the CBT-SP modality practice change at the request of the Suicide Prevention Team Coordinator. Utilizing the DMAIC model data will continue to be collected for maintenance in order to enhance the sustainability of this EBP project. In summation, this EBP project has the potential to decrease suicidal symptomatology, increase the quality of life, and save lives.

\section{Plans for Dissemination}

The EBP change project validated the CBT-SP literature that the intervention decreases suicide ideation, suicide attempts, and self-harm injury as positive treatment outcomes. The results of the project were compared with evidence-based research literature, highlighting the 
positive impact of CBT-SP with Veteran populations. Lastly, at closure there will be discussion on access to training materials, Clinical Practice Guidelines (CPG), and Veterans' Health Administration (VHA) protocol resources for sustainment of the EBP project change. A comprehensive peer review of the EBP project's major components were reviewed and evaluated before dissemination of the results. This process included feedback from both preceptors, course instructor, and selected university peers.

Given the COVID19 pandemic circumstances, the results of the EBP project will be disseminated to internal and external community partners in the form of Microsoft Teams virtually. The Microsoft Teams virtual PowerPoint presentation was presented internally to the Chief and staff of Quality Management Service and internally to the Chief of Psychiatry and Chief of Psychology at the Mental Health \& Behavioral Sciences Service (MH\&BSS) monthly staff meeting. Plans also include submitting a manuscript of the DNP evidence-based project on CBT-SP to the Journal of Veterans Studies because this journal is focused on peer-reviewed, evidence-based interventions for Veterans and major health issues, such as decreasing rates of suicide. This EBP paper will be submitted, as a requirement, in full text to the institutional repository called SOAR@USA to improve the discoverability and availability of the EBP project. Finally, the EBP project will be submitted to The Virginia Henderson Global Nursing eRepository to allow worldwide share of the project information.

\section{Conclusion}

Suicide and suicide prevention are a national health concern that affects Veterans and all Americans whether or not they have served in the military forces. Globally, it is everyone's responsibility to play a role in preventing suicide and the VHA has incorporated a comprehensive public health approach to reduce Veteran suicide rates (The National Strategy for 
Preventing Veteran Suicide, 2018-2028). Cognitive behavioral therapy for suicide prevention (CBT-SP) is theoretically grounded and incorporates evidence-based practice principles of psychological therapy aimed to understand problems associated with the relationship between thoughts, physiological sensations, emotions, and behaviors (Bryan et al., 2018). The primary goal of CBT-SP is to provide patients with education and coping mechanisms to prevent future suicidal acts and self-harm behaviors. This DNP scholarly change project examined evidencebased literature that emphasizes patients with suicide ideation and recent discharge from inpatient psychiatric hospitalization and who follow-up with outpatient mental health providers for CBT-SP versus TAU are less likely to attempt suicide. The results of this DNP scholarly change project were disseminated via a virtual PowerPoint presentation to varying hospital and nursing associations. Future implications, as a result of the EBP project, will provide opportunities for the CBT-SP endeavors. A major implication of this EBT change project is to empower the field of nursing care with the initiative necessary to continue such projects to potentially improve patient safety, increase optimal patient outcomes, and decrease patient mortality. 
References

Adams, L. (2017). Peplau's contributions to nursing knowledge. Journal of Mental Health Addiction Nursing, 1(1): e10-e18. https://doi:10.22374/jmhan.v1i1.3

Agency for Healthcare Research and Quality. (2019). High reliability. Retrieved June 26, 2019 from https://psnet.ahrq.gov/primer/high-reliability

Ahmadizadeh, M., Ahmadi, K., Anisi, J., \& Ahmadi, A. (2013). Assessment of cognitive behavioral therapy on quality of life of patients with chronic war-related post-traumatic stress disorder. Indian Journal Psychological Medicine, 35(4), 341-345. https://doi.org/10.4103/0253-7176.122222

Ahmed, S. (2019). Integrating DMAIC approach of Lean Six Sigma and theory of constraints toward quality improvement in healthcare. https://doi.org/10.1515/reveh-2019-0003

Bonis, S., Taft, L. \& Wendler, M.C. (2007). An evidence-based approach using The ACE STAR model of knowledge transformation. Nursing Education Perspectives, 28(2), 82-87.

Retrieved June 26, 2019 from https://journals.1ww.com/neponline/2007/03000/STRATEGIES_to_Promote_Success_on the NCLEX_RN_An.9.aspx

Brown, G. K., \& Jager-Hyman, S. (2014). Evidence-based psychotherapies for suicide prevention: Future directions. American Journal of Preventative Medicine, 47(3S2), S186-S194. https://doi:10.1016/j.amepre.2014.06.008

Brown, G. K., Karlin, B. E., Trockel, M., Gordienko, M., Yesavage, J., \& Taylor, C. B. (2016). Effectiveness of cognitive behavioral therapy for Veterans with depression and suicidal ideation. Archives of Suicide Research, 20, 677-682. https://doi:10.1080/13811118.2016.1162238 
Brown, G. K., Have, T. T., Henriques, G. R., Xie, S. X., Hollander, J. E., \& Beck, A.T. (2005). Cognitive therapy for the prevention of suicide attempts: A randomized controlled trial. Journal of American Medical Association, 294(5), 563-570. https://doi:10.1001/jama.294.5.563

Bryan, C. J., Peterson, A. L., \& Rudd, M. D. (2018). Differential effects of brief CBT versus treatment as usual on posttreatment suicide attempts among groups of suicidal patients. Psychiatric Services, 69(6), 703-709. https://doi.org/10.1176/appi.ps.201700452

Bryan, C. J., Rozek, D. C., Butner, J., \& Rudd, M. D. (2019). Patterns of change in suicide ideations signal the recurrence of suicide attempts among high-risk psychiatric outpatients. Behaviour Research and Therapy, 120(103392), 1-6. https://doi.org./10.1016/j.brat.2019.04.001

Burckhardt, C., \& Anderson, K. (2003). The quality of life scale (QOLS): Reliability, validity, and utilization. Health Quality of Life Outcomes, 1(60), 1-11. https://doi:10.1186/1477$\underline{7525-1-60}$

Cajanding, R. J. (2016). The effectiveness of nurse-led cognitive-behavioral therapy on the quality of life, self-esteem and mood among Filipino patients living with heart failure: A randomized controlled trial. Applied Nursing Research, 1(31), 86-93. https://doi.org/10.1016/j.apnr.2016.01.002

Calati, R., \& Courtet, P. (2016). Is psychotherapy effective for reducing suicide attempt and nonsuicidal self-injury rates? Meta-analysis and meta-regression of literature data. $J$ Psychiatry Res. 79, 8-20. https://doi:10.1016/j.jpsychires.2016.04.003 
Center for Disease Control and Prevention: National Center for Health Statistics. (2019). Suicide and self-inflicted injury. Retrieved June 26, 2019 from https://www.cdc.gov/nchs/products/databriefs/db330htm

Columbia-Suicide Severity Rating Scale (C-SSRS). (2019). US Department of Health and Human Services: Substance abuse and mental health services administration (SAMHSA). Retrieved June 26, 2019 from https://suicidology.org/

Conwell, Y., Duberstein, P.R., Cox, C., Herrmann, J.H., Forbes, N.T., \& Caine, E.D. (1996). Relationships of age and axis I diagnosis in victims of completed suicide: A psychological autopsy study. American Journal of Psychology, 153(8), 1001-1008.

Correa-de Araujo, R. (2016). Evidence-based practice in the United States: Challenges, progress, and future directions. Health Care Women International, 37(1), 2-22. https://doi:10.1080/07399332.2015.1102269

Dearholt, S.L., \& Dang, D. (2012). Johns Hopkins nursing evidence-based practice: Model and guidelines $\left(2^{\text {nd }}\right.$ ed.). Sigma Theta Tau International.

Flanagan, J. C. (1970). Quality of life scale. American Thoracic Society.

Retrieved June 26, 2019 from https://qol.thoracic.org/sections/instruments/fj/pages/flan.html

Ghahramanlou-Holloway, M., Neely, L.L., Tucker, J., Caffery, K., Colborn, V., \& Koltko, V. (2015). Inpatient cognitive behavior therapy approaches for suicide prevention. Current Treatment Options Psychiatry 2, 271-382. http://doi:10.1007/s40501-015-0063-4

Gotzsche, P. C., \& Gotzsche, P. K. (2017). Cognitive behavioral therapy halves the risk of repeated suicide attempts: Systematic review. The Royal Society of Medicine, 110(10), 404-410. https://doi.org/10.1177/0141076817731904 
Green, J. (2019). IPE 7230 program/project planning and management for practice and policy change course syllabus and rubric. University of St. Augustine for Health Sciences, $1-9$.

Haddock, G., Davies, L., Evans, E., Emsley, R., Gooding, P., Heaney, L., Jones, S., Kelly, J., Munro, A., Peters, S., Pratt, D., Tarrier, N., Windfuhr, K., \& Awenat, Y. (2016). Investigating the feasibility and acceptability of cognitive behavioral suicide prevention therapy for people in acute psychiatric wards (the INSITE trial): Study protocol for a randomized controlled trial. Open Access, 17(79): 1-8. https://doi.org/10.1186/s13063-1192-9

Health IT-National Learning Consortium. (2013). Continuous quality Improvement (CQI) strategies to optimize your practice, Version 1.0. Retrieved June 26, 2019 from https://www.healthit.gov/sites/default/files/tools/nlc_continuousqualityimprovement

Hogan, M.F., \& Grumet, J.G. (2016). Suicide prevention: An emerging priority for health care. Health Affairs, 35(6), 1084-1090. https://doi.org/10.1377/hlthaff.2015.1672

Huang, X. (2017). Demographics as predictors of suicidal thoughts and behaviors: A metaanalysis. PLoS One, 12(7), e0180793: 1-28. https://doi.org/10.1371/joural.pone.0180793

Institute for Healthcare Improvement. (2019). Quality improvement essentials toolkit. Retrieved June 26, 2019 from http://www.ihi.org/resources/Pages/Tools/Quality-Improvement-Essentials-Toolkit.aspx

Jobes, D. A. (2102). The collaborative assessment and management of suicidality (CAMS): An evolving evidence-based clinical approach to suicide risk. Suicide and Life- 
Threatening Behavior, 42(6):640-653. https://doi:10.1111/j.1943-278X.2012.00119.x

Kogon, K., Blakemore, S., \& Wood, J. (2015). Project management for the unofficial project manager. BenBella Books, Inc.

Kumar, S., \& McKewan, G. (2011). Six Sigma DMAIC quality study: Expanded nurse practitioner's role in health care during and posthospitalization within the United States. Home Health Care Management \& Practice, 23(4): 271-282. https://doi.org/10.1177/1084822310388385.

Larkin, W. (2019). SQUIRE 2.0. Unpublished manuscript, University of St. Augustine for Health Sciences.

Larkin, W. (2019). Project change timeline. Unpublished manuscript, University of St. Augustine for Health Sciences.

Larkin, W. (2019). Status of a project plan for quality improvement. Unpublished manuscript, University of St. Augustine for Health Sciences.

Lobban, F., Postlethwaite, A., Glenworth, D., Pinfold, V., Wainwright, L., Dunn, G., Clancy, A., \& Haddock, G. (2013). A systematic review of randomized controlled trials of interventions reporting outcomes for relative of people with psychosis. Clinical Psychology Review, 33, 372-382. Retrieved June 26, 2019 from https://www.sciencedirect.com/science/article/pii/S0272735812001882

Mewton, L., \& Andrews, G. (2016). Cognitive behavioral therapy for suicidal behaviors: Improving patient outcomes. Psychology Research and Behavior Management, 9, 21-29. https://doi.org/10.2147/PRBM.S84589 
National Veteran Suicide Prevention Annual Report. (2019). U.S. Department of Veterans Affairs. Office of Mental Health and Suicide Prevention, 1-30. Retrieved June 26, 2019 from https://nexusipe.org/advancing/assessment-evaluation

Newhouse, R., Dearholt, S., Poe, S., Pugh, L.C., \& White, K. (2005). The Johns Hopkins nursing evidence-based practice rating scale. The Johns Hopkins Hospital.

Posner, K., Brown, G., Stanley, B., Brent, D., Yershova, K., Oguendo, M., Currier, G., Melvin, G., Greenhill, L., Shen, S., \& Mann, J. (2014). The columbia-suicide security rating scale: Initial validity and internal consistency findings from three multisite studies with adolescents and adults. The American Journal of Psychiatry, 168(12), 1266-1277. https://doi.org/10.1176/appi.ajp.2011.1011704

Riblet, N., Shiner, B., Watts, B., Mills, P., Rusch, B., \& Hemphill, R. R. (2017). Death by suicide within 1 week of hospital discharge: A retrospective study of root cause analysis reports. The Journal of Nervous and Mental Disease, 205(6), 436-442. https://doi.org/10.1097/NMD.0000000000000687

Rudd, M. D., Bryan, C. J., Wertenberger, E. G., Peterson, A. L., Young-McCaughan, S., Mintz, J., Williams, S. R., Arne, K. A., Breitbach, J., Delano, K., Wilkinson, R., \& Bruce, T. (2015). Brief cognitive-behavioral therapy effects on post-treatment suicide attempts in a military sample: Results of a randomized clinical trial with 2-year follow-up. The American Journal of Psychiatry, 172(5), 441-449. https://doi.org/10.1176/appi.ajp.2014.14070843

Sasal, D. (2018, November 8). Project management simplified: Learn the fundamentals of PMI's framework. [Video]. YouTube. https://www.youtube.com/watch?v=ZKOL-rZ79gs 
Sentinel Alert Event. (2016). Detecting and Treating Suicide Ideation in all Settings. The Joint Commission Issue, 56.

Stevens, K. R. (2010). Evidence-based practice: Destination or journey? Nurse Outlook, 58(6), 273-275. https://doi:10.1016/j.outlook.2010.09.002

Stevens, K. R. (2013). The impact of evidence-based practice in nursing and the next big ideas. The Online Journal of Issues in Nursing, 18(2). https://doi.org/10.3912/OJIN.Vol18No02Man04

Tarrier, N., Taylor, K., \& Gooding, P. (2008). Cognitive behavioral interventions to reduce suicide behavior: A systematic review and meta-analysis. Behavior Modification, 32(1), 77-108. https://doi.org/10.1177/014545507304728

Trajkovic, G., Starcevic, V., Latas, M., Lestarevic, M., Ille, T., Bukumiric, Z., \& Marinkovic, J. (2011). Reliability of the Hamilton rating scale for depression: A meta-analysis over a period of 49 years. Psychiatry Research, 189, 1-9. https://doi.org/10.1016/j.psychres.2010.12.007

United States Department of Health and Human Services, Health Resources and Services Administration. (2011). Quality Improvement. Retrieved from https://www.hrsa.gov/sites/default/files/quality/toolbox/508pdfs/qualityimprovement.pdf

United States Department of Veterans Affairs. (2018). National strategy for preventing veteran suicide: 2018-2028. Office of Mental Health and Suicide Prevention. Retrieved from https://www.mentalhealth.va.gov/suicide_prevention/docs/Office-of-Mental-Health-andSuicide-Prevention-National-Strategy-for-Preventing-Veterans-Suicide.pdf 
VA/DoD Clinical Practice Guidelines for the Assessment and Management of Patients at Risk for Suicide. (2019). Retrieved from https://www.healthquality.va.gov/guidelines/MH/srb/VADoDSuicideRiskFullCPGFinal5 088212019.pdf

Wang, Y-P., \& Gorenstein, C. (2013). Psychometric properties of the beck depression inventory II: A comprehensive review. Revista Brasileira de Psiquiatria, 35(4), 416-431. https://doi.org/10.1590/1516--4446-2012-1048

Watts, S., Turnell, A., Kladnitski, N., Newby, J. M., \& Andrews, G. (2015). Treatment as usual (TAU) is anything but usual: A meta-analysis of CBT versus TAU for a depression. The Journal of Affective Disorders, 175, 152-167. https://doi:10.1016/j.jad.2014.12.025

Witt, K., Pache de Moraes, D., Salisbury, T.T., Arensman, E., Gunnell, D. Hazell, P., Townsend, E., van Heeringen, K., \& Hawton, K. (2018). Treatment as usual (TAU) as a control condition in trials of cognitive behavioral based psychotherapy for self-harm: Impact of content and quality on outcomes in a systematic review. Journal of Affective Disorders, 235, 434-447. https://doi:10.1016/j.jad.2018.04.025 
Table 1

Summary of Table on Strength and Quality of Evidence

\begin{tabular}{|c|c|c|c|c|}
\hline \multicolumn{5}{|c|}{ Summary of Table on Strength of Evidence } \\
\hline $\begin{array}{c}\text { Number of } \\
\text { Studies }\end{array}$ & Level & Grade & Quality of Studies & $\begin{array}{c}\text { Evidence } \\
\text { Grade }\end{array}$ \\
\hline 12 RCTs & $\begin{array}{l}\text { Level } 1=5 \text { studies } \\
\text { Level } 2=6 \text { studies } \\
\text { Level } 3=1 \text { study }\end{array}$ & $\begin{array}{l}\text { Grade } A=6 \\
\text { studies } \\
\text { Grade } B=5 \\
\text { studies } \\
\text { Grade C }=1 \\
\text { study }\end{array}$ & $\begin{array}{l}\text { All studies are RCT } \\
\text { Single RCT studies }=6 \\
\text { Systematic Reviews }=6\end{array}$ & $\begin{array}{l}\text { Overall } \\
\text { strength of } \\
\text { the } \\
\text { aggregate } \\
\text { research } \\
\text { has a High- } \\
\text { Moderate } \\
\text { grade }\end{array}$ \\
\hline
\end{tabular}

Strength of the Evidence

Level I Experimental study/randomized controlled trial (RCT) or meta-analysis of

RCT

Level II Quasi-experimental study

Level III Non-experimental study, qualitative study, or meta-synthesis

Level IV Opinion of nationally recognized experts based on research evidence or expert consensus panel (systematic review, clinical practice guidelines)

Level V Opinion of individual expert based on non-research evidence. (Includes case studies; literature review; organizational experience e.g., quality improvement and financial data; clinical expertise, or personal experience)

\begin{tabular}{|c|c|c|c|}
\hline \multicolumn{4}{|c|}{ Quality of the Evidence } \\
\hline & High & Research & $\begin{array}{l}\text { consistent results with sufficient sample size, } \\
\text { adequate control, and definitive conclusions; } \\
\text { consistent recommendations based on extensive } \\
\text { literature review that includes thoughtful reference } \\
\text { to scientific evidence. }\end{array}$ \\
\hline & & Summative reviews & $\begin{array}{l}\text { well-defined, reproducible search strategies; } \\
\text { consistent results with sufficient numbers of well- } \\
\text { defined studies; criteria-based evaluation of overall } \\
\text { scientific strength and quality of included studies; } \\
\text { definitive conclusions }\end{array}$ \\
\hline & & Organizational & $\begin{array}{l}\text { well-defined methods using a rigorous approach; } \\
\text { consistent results with sufficient sample size; use } \\
\text { of reliable and valid measures }\end{array}$ \\
\hline & & Expert Opinion & expertise is clearly evident \\
\hline & Good & Research & $\begin{array}{l}\text { reasonably consistent results, sufficient sample } \\
\text { size, some control, with fairly definitive }\end{array}$ \\
\hline
\end{tabular}




\begin{tabular}{|c|c|c|}
\hline & $\begin{array}{l}\text { Summative } \\
\text { reviews }\end{array}$ & $\begin{array}{l}\text { conclusions; reasonably consistent } \\
\text { recommendations based on fairly comprehensive } \\
\text { literature review that includes some reference to } \\
\text { scientific evidence } \\
\text { reasonably thorough and appropriate search; } \\
\text { reasonably consistent results with sufficient } \\
\text { numbers of well } \\
\text { defined studies; evaluation of strengths and } \\
\text { limitations of included studies; fairly definitive } \\
\text { conclusions. } \\
\text { Well-defined methods; reasonably consistent } \\
\text { results with sufficient numbers; use of reliable and } \\
\text { valid measures; reasonably consistent } \\
\text { recommendations } \\
\text { expertise appears to be credible. }\end{array}$ \\
\hline $\begin{array}{l}\text { C Low } \\
\text { quality or } \\
\text { major flaws }\end{array}$ & Research & $\begin{array}{l}\text { little evidence with inconsistent results, } \\
\text { insufficient sample size, conclusions cannot be } \\
\text { drawn }\end{array}$ \\
\hline & Summative reviews & $\begin{array}{l}\text { undefined, poorly defined, or limited search } \\
\text { strategies; insufficient evidence with inconsistent } \\
\text { results; conclusions cannot be drawn }\end{array}$ \\
\hline & Organizational & $\begin{array}{l}\text { Undefined, or poorly defined methods; insufficient } \\
\text { sample size; inconsistent results; undefined, poorly } \\
\text { defined or measures that lack adequate reliability } \\
\text { or validity }\end{array}$ \\
\hline & xpert Opinion & expertise is not discernable or is dubious. \\
\hline \multicolumn{3}{|c|}{ Appraising the Body of Evidence } \\
\hline Grade & & Method \\
\hline High & \multicolumn{2}{|c|}{$\begin{array}{l}\text { Multiple studies, unless large effect and very clinically important. Strong designs for } \\
\text { answering the question addressed. Clinically important and consistent results with minor } \\
\text { exceptions at most. Free of any significant doubts about validity (generalizability, bias, } \\
\text { design flaws). Adequate statistical power (including studies showing no difference). }\end{array}$} \\
\hline Moderate & \multicolumn{2}{|c|}{$\begin{array}{l}\text { Multiple studies. Strong designs for answering the question addressed. Some uncertainty } \\
\text { due to either validity threats (generalizability, bias, design flaws or adequacy of statistical } \\
\text { power) or inconsistency. Consistency. }\end{array}$} \\
\hline Low & \multicolumn{2}{|c|}{$\begin{array}{l}\text { Health professional opinion is the only relevant published information. Local consensus is } \\
\text { clear. Uncertainty due to either validity threats (generalizability, bias, design flaws or } \\
\text { adequacy of statistical power). Inconsistency. }\end{array}$} \\
\hline $\begin{array}{l}\text { Grade not } \\
\text { assignable }\end{array}$ & \multicolumn{2}{|c|}{$\begin{array}{l}\text { Studies have not been done, or published studies are seriously flawed, and/or published } \\
\text { studies give inconsistent results. There is insufficient evidence and lack of consensus to } \\
\text { answer the clinical question. }\end{array}$} \\
\hline
\end{tabular}




\section{Table 2}

Budget for DNP Project

\begin{tabular}{cc}
\hline \multicolumn{2}{c}{ Budget } \\
\hline Expenses & Costs \\
\hline Training staff & $\$ 478.00$ \\
Educational materials/resources & $\$ 300.00$ \\
Poster-board with results table & $\$ 150.00$ \\
Food/beverages & $\$ 175.00$ \\
Registration fee & $\$ 100.00$ \\
Total Expenses & $\$ 1,203.00$ \\
\hline
\end{tabular}




\section{Table 3}

Variables and Measures of Demographic Data

\begin{tabular}{|c|c|c|c|c|c|}
\hline Variable & $\begin{array}{l}\text { Variable } \\
\text { Description }\end{array}$ & Data Source & $\begin{array}{l}\text { Range of } \\
\text { Values }\end{array}$ & $\begin{array}{l}\text { Level of } \\
\text { Measurement }\end{array}$ & $\begin{array}{l}\text { Time } \\
\text { Frame for } \\
\text { Collection }\end{array}$ \\
\hline \multicolumn{6}{|c|}{ Population } \\
\hline Age & $\begin{array}{c}18-65 \text { years } \\
\text { (adult) }\end{array}$ & $\begin{array}{l}\text { Electronic Medical } \\
\text { Record }\end{array}$ & $\begin{array}{l}18-25=1 \\
26-35=2 \\
36-43=3 \\
44-51=4 \\
52-59=5 \\
60>=6\end{array}$ & ratio & $\begin{array}{l}\text { When } \\
\text { patient is } \\
\text { enrolled in } \\
\text { project }\end{array}$ \\
\hline Gender & Gender & $\begin{array}{l}\text { Electronic Medical } \\
\text { Record }\end{array}$ & $\begin{array}{c}0=\text { male } \\
1=\text { female }\end{array}$ & nominal & $\begin{array}{l}\text { When } \\
\text { patient is } \\
\text { enrolled in } \\
\text { project }\end{array}$ \\
\hline Depression & $\begin{array}{l}\text { Depression } \\
\text { with resultant } \\
\text { positive } \\
\text { Suicide } \\
\text { Ideation (SI) }\end{array}$ & $\begin{array}{l}\text { Electronic Medical } \\
\text { Record } \\
\text { Risk of SI }\end{array}$ & $\begin{array}{c}0=\mathrm{SI} \\
1=\mathrm{No} \mathrm{SI}\end{array}$ & nominal & $\begin{array}{l}\text { At hospital } \\
\text { admission, } \\
\text { discharge } \\
\text { and potential } \\
\text { reassessment } \\
\text { throughout } \\
\text { therapy }\end{array}$ \\
\hline \multicolumn{6}{|c|}{ Events } \\
\hline $\begin{array}{l}\text { Columbia } \\
\text { Suicide } \\
\text { Severity } \\
\text { Rating } \\
\text { Scale (C- } \\
\text { SSRS) }\end{array}$ & $\begin{array}{l}\text { C-SSRS used } \\
\text { to complete } \\
\text { suicide risk } \\
\text { assessments on } \\
\text { all patients } \\
\text { diagnosed with } \\
\text { SI in the VHA. } \\
\text { The C-SSRS is } \\
\text { a highly } \\
\text { predictive } \\
\text { measure of } \\
\text { validity and } \\
\text { reliability }\end{array}$ & $\begin{array}{l}\text { Electronic Medical } \\
\text { Record - C-SSRS SI } \\
\text { Risk Assessment }\end{array}$ & $\begin{array}{l}1=\text { positive } \\
2=\text { negative }\end{array}$ & nominal & $\begin{array}{l}\text { C-SSRS } \\
\text { completed at } \\
\text { hospital } \\
\text { admission, } \\
\text { discharge } \\
\text { and potential } \\
\text { reassessment } \\
\text { throughout } \\
\text { therapy }\end{array}$ \\
\hline
\end{tabular}




\begin{tabular}{|c|c|c|c|c|c|}
\hline $\begin{array}{l}\text { Cognitive } \\
\text { Behavioral } \\
\text { Therapy- } \\
\text { Suicide } \\
\text { Prevention } \\
\text { (CBT-SP) }\end{array}$ & $\begin{array}{l}\text { CBT-SP is } \\
\text { theoretically } \\
\text { grounded and } \\
\text { incorporates } \\
\text { evidence-based } \\
\text { practice } \\
\text { principles of } \\
\text { psychological } \\
\text { therapy aimed } \\
\text { to understand } \\
\text { problems } \\
\text { associated with } \\
\text { the relationship } \\
\text { between } \\
\text { thoughts, } \\
\text { physiological } \\
\text { sensations, } \\
\text { emotions, and } \\
\text { behaviors }\end{array}$ & $\begin{array}{ll}\text { - CBT-SP } \\
\text { Clinical } \\
\text { Practice } \\
\text { Guidelines } \\
\text { - } & \text { Electronic } \\
\text { Medical } \\
\text { Record } \\
\text { review for } \\
\text { readmission } \\
\text { Baseline } \\
\text { questionnaire } \\
\text { End of } \\
\text { therapy } \\
\text { questionnaire }\end{array}$ & $\begin{array}{l}\text { Use actual } \\
\text { number of } \\
\text { readmission }\end{array}$ & $\begin{array}{l}\text { Algorithms } \\
\text { (Yes/No) - } \\
\text { nominal } \\
\text { Text } \\
\text { Descriptive } \\
\text { answers - } \\
\text { Text } \\
\text { Descriptive } \\
\text { answers - } \\
\text { Text }\end{array}$ & $\begin{array}{l}\text { Onset of } \\
\text { intervention } \\
(4 / 5 / 2020) \\
\text { Onset of } \\
\text { intervention } \\
\text { and } \\
\text { throughout } \\
\text { 12-week } \\
\text { therapy } \\
\text { Onset of } \\
\text { intervention } \\
\text { (baseline) } \\
\text { End of } 12 \\
\text { week } \\
\text { intervention }\end{array}$ \\
\hline \multicolumn{6}{|c|}{ Outcome } \\
\hline $\begin{array}{l}\text { Reduce } \\
\text { suicide } \\
\text { and } \\
\text { attempts of } \\
\text { suicide. } \\
\text { Quality of } \\
\text { Life tool } \\
\text { will } \\
\text { increase } \\
\text { C-SSRS } \\
\text { will be } \\
\text { negative }\end{array}$ & $\begin{array}{l}\text { The } \\
\text { independent } \\
\text { variable in this } \\
\text { project is the } \\
\text { implementation } \\
\text { of the CBT-SP } \\
\text { therapy. One } \\
\text { dependent } \\
\text { variable is the } \\
\text { number of } \\
\text { patients who } \\
\text { experienced } \\
\text { CBT-SP } \\
\text { therapy and are } \\
\text { either not } \\
\text { readmitted or } \\
\text { are readmitted } \\
\text { to the hospital, } \\
\text { but not for } \\
\text { suicidal } \\
\text { ideation, post } \\
\text { one month } \\
\text { after CBT-SP } \\
\text { therapy. The } \\
\text { second } \\
\text { dependent } \\
\text { variable is the } \\
\text { number of } \\
\text { patients who } \\
\text { underwent } \\
\text { CBT-SP }\end{array}$ & $\begin{array}{l}\text { Baseline Quality of } \\
\text { Life tool and C- } \\
\text { SSRS questionnaire } \\
\text { End of therapy } \\
\text { Quality of Life tool } \\
\text { and C-SSRS } \\
\text { questionnaire }\end{array}$ & $\begin{array}{l}\text { Quality of } \\
\text { Life tool = } \\
1-7 . \text { C- } \\
\text { SSRS = } \\
\text { yes/no }\end{array}$ & $\begin{array}{l}\text { Quality of } \\
\text { Life } \\
=\text { Ordinal } \\
\text { C-SSR = } \\
\text { nominal }\end{array}$ & $\begin{array}{l}\text { Baseline and } \\
\text { end of } \\
\text { therapy }\end{array}$ \\
\hline
\end{tabular}


therapy and

experienced a perceived

increase in satisfaction on the Quality of Life scale. 


\section{Figure 1}

Stevens ACE Star Model of Knowledge Transformation

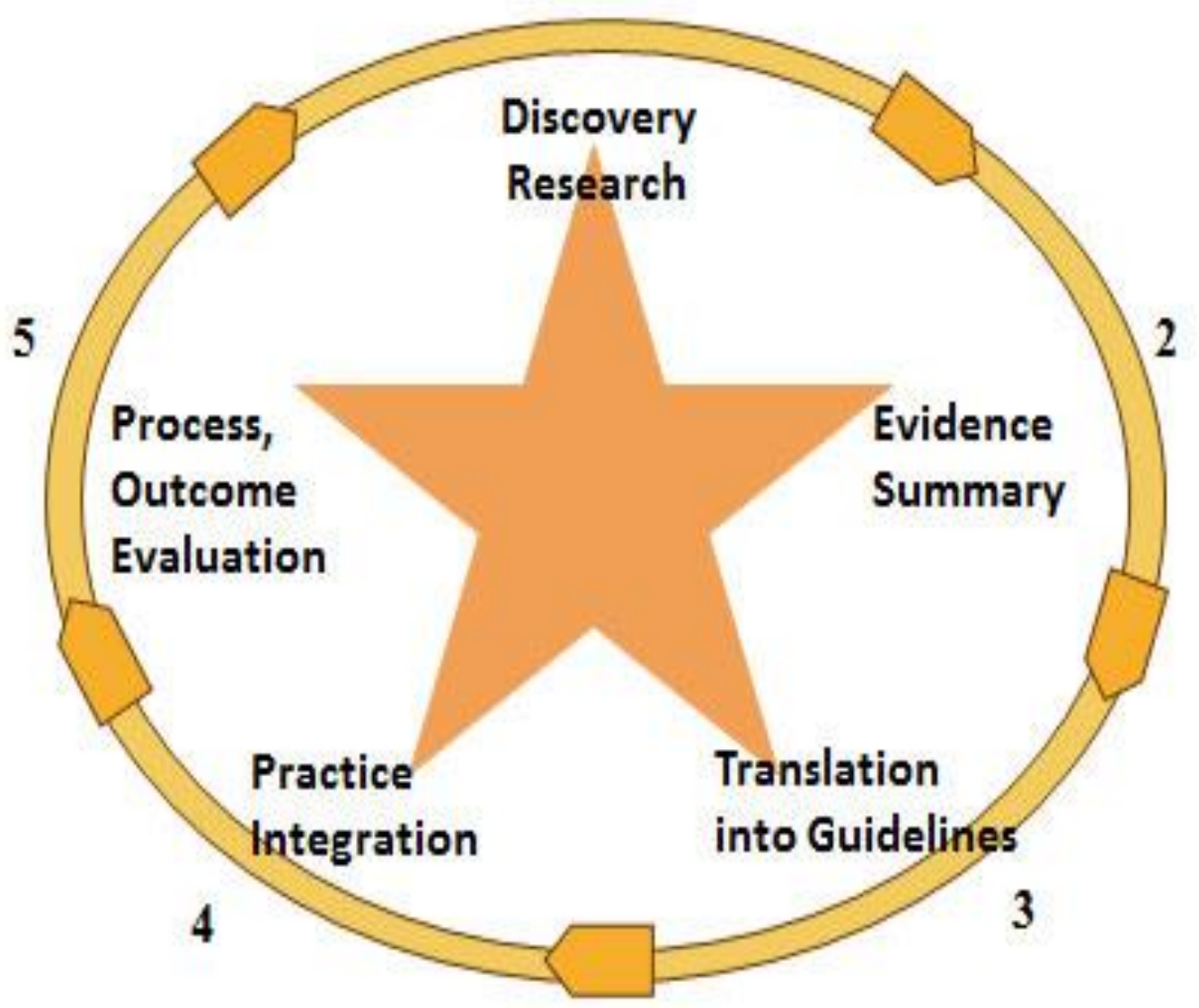




\section{Figure 2}

Prisma Model Summary

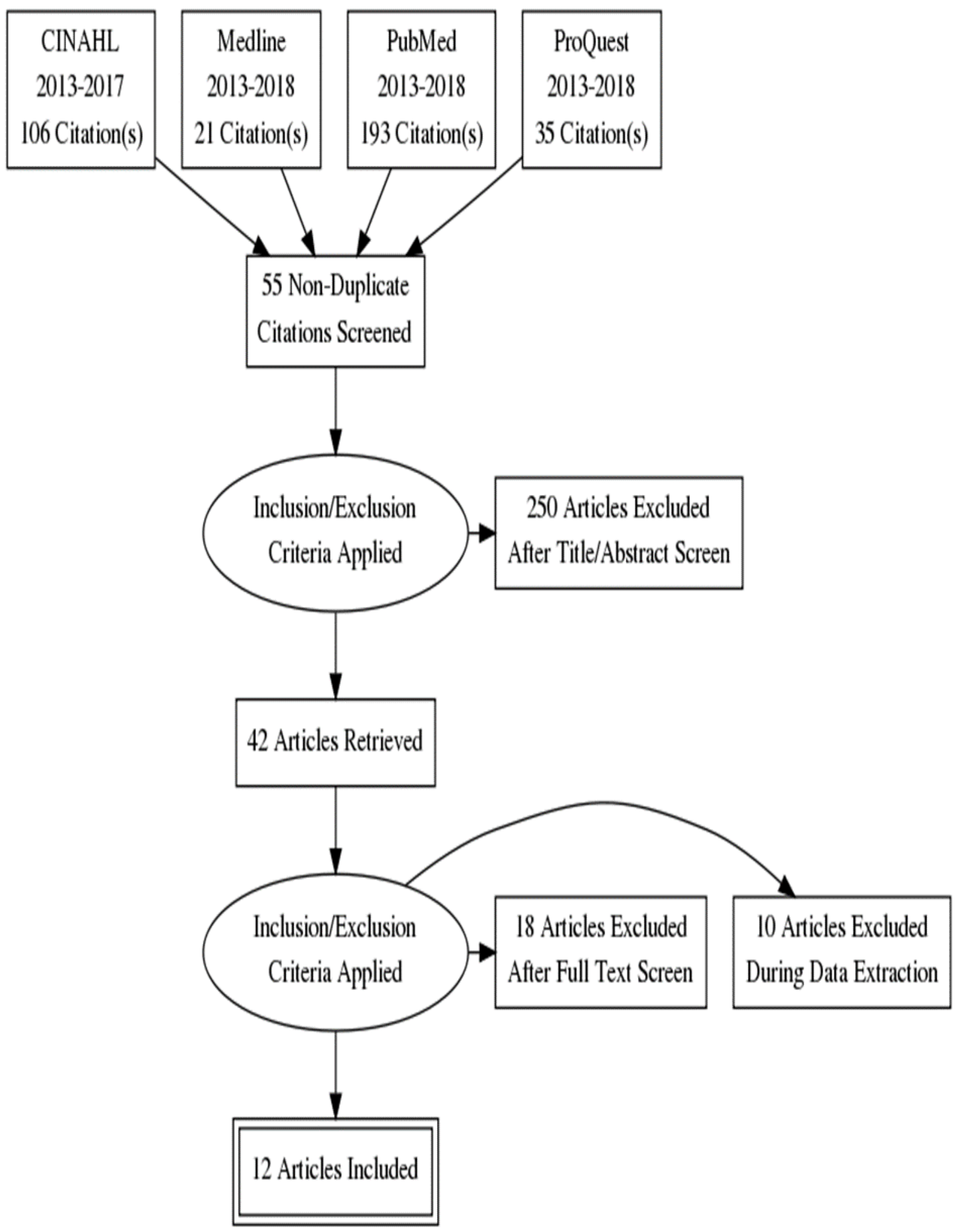




\section{Figure 3}

DMAIC Model

\section{DMAIC}

DMAIC is a five-step method for improving existing process problems with unknown causes.

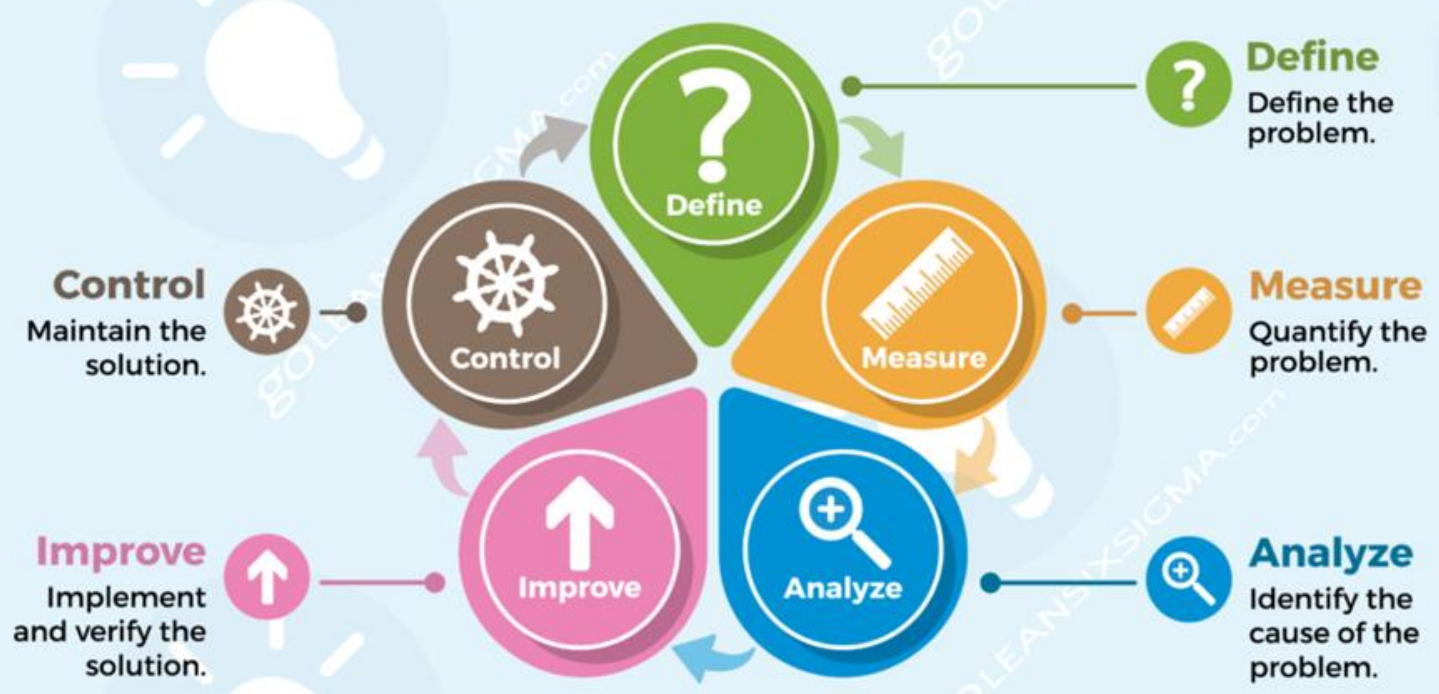




\title{
Appendix A
}

\section{Quality of Life Scale}

\section{QUALITY OF LIFE SCALE (QOL)}

Please read each item and circle the number that best describes how satisfied you are at this time. Please answer each item even if you do not currently participate in an activity or have a relationship. You can be satisfied or dissatisfied with not doing the activity or having the relationship.

1. Material comforts home, food, conveniences,

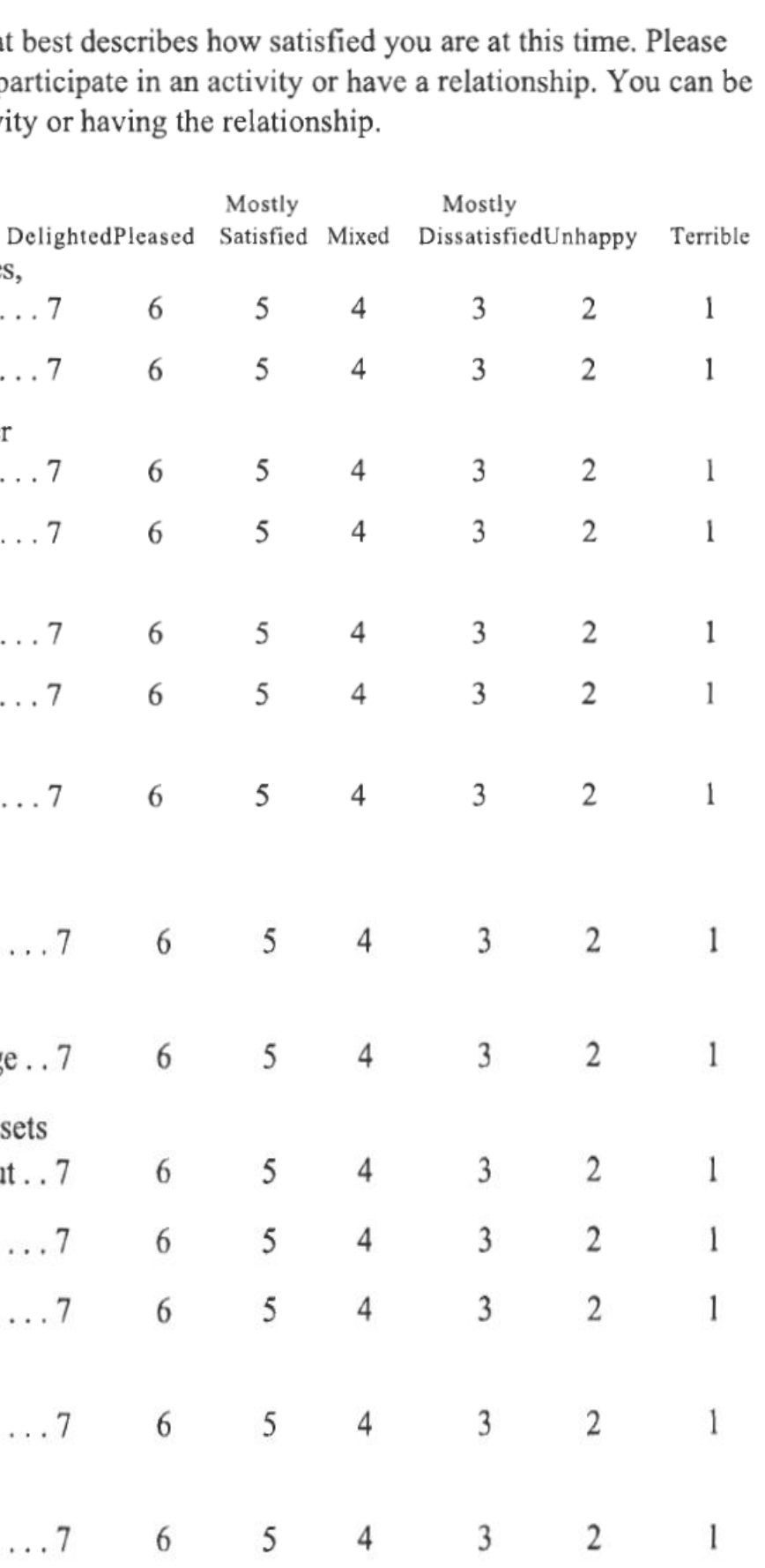

financial security . . . . . . . . . . . . . .

2. Health - being physically fit and vigorous ...

\begin{tabular}{|c|c|c|c|c|}
\hline \multirow{2}{*}{$\begin{array}{l}\text { Pleased } \\
6\end{array}$} & \multirow{2}{*}{$\begin{array}{c}\text { Mostly } \\
\text { Satisfied } \\
5\end{array}$} & \multirow{2}{*}{$\begin{array}{c}\text { Mixed } \\
\quad 4\end{array}$} & \multicolumn{2}{|c|}{$\begin{array}{l}\text { Mostly } \\
\text { DissatisfiedUnhappy }\end{array}$} \\
\hline & & & 3 & 2 \\
\hline 6 & 5 & 4 & 3 & 2 \\
\hline 6 & 5 & 4 & 3 & 2 \\
\hline 6 & 5 & 4 & 3 & 2 \\
\hline 6 & 5 & 4 & 3 & 2 \\
\hline 6 & 5 & 4 & 3 & 2 \\
\hline 6 & 5 & 4 & 3 & 2 \\
\hline 6 & 5 & 4 & 3 & 2 \\
\hline 6 & 5 & 4 & 3 & 2 \\
\hline 6 & 5 & 4 & 3 & 2 \\
\hline 6 & 5 & 4 & 3 & 2 \\
\hline 6 & 5 & 4 & 3 & 2 \\
\hline 6 & 5 & 4 & 3 & 2 \\
\hline 6 & 5 & 4 & 3 & 2 \\
\hline
\end{tabular}

3. Relationships with parents, siblings \& other relatives- communicating, visiting, helping ... .

4. Having and rearing children ............

7

5. Close relationships with spouse or significant other ................

6. Close friends $\ldots \ldots \ldots \ldots \ldots \ldots \ldots \ldots$

7. Helping and encouraging others, volunteering, giving advice

6

\begin{tabular}{|c|c|c|c|}
\hline $\begin{array}{l}\text { Mostly } \\
\text { Satisfied }\end{array}$ & Mixed & $\begin{array}{l}\text { Most! } \\
\text { Dissatis }\end{array}$ & nhappy \\
\hline 5 & 4 & 3 & 2 \\
\hline 5 & 4 & 3 & 2 \\
\hline 5 & 4 & 3 & 2 \\
\hline 5 & 4 & 3 & 2 \\
\hline 5 & 4 & 3 & 2 \\
\hline 5 & 4 & 3 & 2 \\
\hline 5 & 4 & 3 & 2 \\
\hline 5 & 4 & 3 & 2 \\
\hline 5 & 4 & 3 & 2 \\
\hline 5 & 4 & 3 & 2 \\
\hline 5 & 4 & 3 & 2 \\
\hline 5 & 4 & 3 & 2 \\
\hline 5 & 4 & 3 & 2 \\
\hline 5 & 4 & 3 & 2 \\
\hline
\end{tabular}

\begin{tabular}{|c|c|c|c|c|}
\hline $\begin{array}{c}\text { Mostly } \\
\text { Satisfied }\end{array}$ & Mixed & $\begin{array}{l}\text { Mostl } \\
\text { Dissatis }\end{array}$ & nhappy & Terribl \\
\hline 5 & 4 & 3 & 2 & 1 \\
\hline 5 & 4 & 3 & 2 & 1 \\
\hline 5 & 4 & 3 & 2 & 1 \\
\hline 5 & 4 & 3 & 2 & 1 \\
\hline 5 & 4 & 3 & 2 & 1 \\
\hline 5 & 4 & 3 & 2 & 1 \\
\hline 5 & 4 & 3 & 2 & 1 \\
\hline 5 & 4 & 3 & 2 & 1 \\
\hline 5 & 4 & 3 & 2 & 1 \\
\hline 5 & 4 & 3 & 2 & 1 \\
\hline 5 & 4 & 3 & 2 & 1 \\
\hline 5 & 4 & 3 & 2 & 1 \\
\hline 5 & 4 & 3 & 2 & 1 \\
\hline 5 & 4 & 3 & 2 & 1 \\
\hline
\end{tabular}

Participating in organizations and

public affairs $\ldots \ldots \ldots \ldots \ldots \ldots \ldots \ldots 7$

9. Learning- attending school, improving understanding, getting additional knowledge . . 7

10. Understanding yourself - knowing your assets and limitations - knowing what life is about . . 7

11. Work - job or in home ............. 7

12. Expressing yourself creatively $\ldots \ldots \ldots \ldots 7$

13. Socializing - meeting other people, doing things, parties, etc

14. Reading, listening to music, or observing entertainment ................... 7

15. Participating in active recreation ........ 7

16. Independence, doing for yourself . .7

e

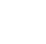




\section{Appendix B}

\section{Themes of Evidence}

\begin{tabular}{|c|c|c|c|c|c|c|}
\hline \multirow[b]{2}{*}{ Citation } & \multicolumn{5}{|c|}{ Intervention } & \multirow[b]{2}{*}{$\begin{array}{l}\text { Usefulness } \\
\text { Results } \\
\text { Key Findings }\end{array}$} \\
\hline & $\begin{array}{l}\text { Design, Level } \\
\text { Quality Grade }\end{array}$ & $\begin{array}{l}\text { Sample } \\
\text { Sample } \\
\text { size }\end{array}$ & $\begin{array}{l}\text { Comparison } \\
\text { (Definitions } \\
\text { should } \\
\text { include any } \\
\text { specific } \\
\text { research tools } \\
\text { used along } \\
\text { with } \\
\text { reliability \& } \\
\text { validity) }\end{array}$ & $\begin{array}{l}\text { Theoretical } \\
\text { Foundation }\end{array}$ & $\begin{array}{c}\text { Outcome } \\
\text { Definition }\end{array}$ & \\
\hline \multicolumn{7}{|c|}{ Cognitive Behavioral Therapy versus Treatment as Usual } \\
\hline $\begin{array}{l}\text { Bryan C.J., } \\
\text { Peterson } \\
\text { A.L., Rudd } \\
\text { M.D. (2018). } \\
\text { Differential } \\
\text { Effects of } \\
\text { Brief CBT } \\
\text { Versus } \\
\text { Treatment as } \\
\text { Usual (TAU) } \\
\text { on } \\
\text { Posttreatment } \\
\text { Suicide } \\
\text { Attempts } \\
\text { Among } \\
\text { Groups of } \\
\text { Suicidal } \\
\text { Patients. } \\
\text { Psychiatric } \\
\text { Services, } \\
\text { 69(6), 703- } \\
709 .\end{array}$ & $\begin{array}{l}\text { Randomized } \\
\text { Controlled } \\
\text { Trial (RCT), } \\
\text { descriptive, } \\
\text { Level I Grade } \\
\text { A due to a two- } \\
\text { year } \\
\text { longitudinal } \\
\text { study with a } \\
\text { sample size of } \\
\text { 176 US } \\
\text { military } \\
\text { personnel }\end{array}$ & $\begin{array}{l}176 \text { US } \\
\text { military } \\
\text { personnel } \\
\text { with } \\
\text { suicide } \\
\text { ideation } \\
\text { within the } \\
\text { past week } \\
\text { or suicide } \\
\text { attempt in } \\
\text { the past } \\
\text { month. }\end{array}$ & $\begin{array}{l}\text { Research tool } \\
\text { used Suicide } \\
\text { Attempt Self- } \\
\text { Injury } \\
\text { Interview } \\
\text { (SASII). } \\
\text { Depression } \\
\text { assessed with } \\
\text { the Beck } \\
\text { Depression } \\
\text { Inventory- } \\
\text { Second } \\
\text { Edition. } \\
\text { Recent (past } \\
\text { week) suicide } \\
\text { ideation was } \\
\text { assessed } \\
\text { using the } \\
\text { Scale for } \\
\text { Suicide } \\
\text { Ideation: } \\
\text { Identification } \\
\text { of treatment } \\
\text { across classes } \\
\text { was } \\
\text { identified } \\
\text { using the } \\
\text { Kaplan- } \\
\text { Meier } \\
\text { method and } \\
\text { Cox } \\
\text { regression. }\end{array}$ & $\begin{array}{l}\text { No } \\
\text { theoretical } \\
\text { framework } \\
\text { is } \\
\text { documented } \\
\text { in the study; } \\
\text { however, } \\
\text { Beck's } \\
\text { Cognitive } \\
\text { Therapy has } \\
\text { been widely } \\
\text { used in } \\
\text { cases of } \\
\text { depression } \\
\text { and may be } \\
\text { applicable as } \\
\text { a means of } \\
\text { decreasing } \\
\text { symptoms of } \\
\text { depression. } \\
\text { Beck } \\
\text { identified } \\
\text { three } \\
\text { mechanisms } \\
\text { responsible } \\
\text { for } \\
\text { depression; } \\
1 \text { ) The } \\
\text { cognitive } \\
\text { triad; 2) } \\
\text { negative } \\
\text { self- } \\
\text { schemas; } \\
\text { and } 3 \text { ) } \\
\text { Errors in } \\
\text { Logic. }\end{array}$ & $\begin{array}{l}\text { Outcome } \\
\text { was TAU } \\
\text { was } \\
\text { associated } \\
\text { with } \\
\text { variable } \\
\text { rates of } \\
\text { suicidal } \\
\text { behaviors } \\
\text { depending } \\
\text { on the risk } \\
\text { of suicide } \\
\text { severity. } \\
\text { Brief } \\
\text { CBT-SP } \\
\text { was } \\
\text { effective } \\
\text { in } \\
\text { contributi } \\
\text { ng to low } \\
\text { rates of } \\
\text { suicidal } \\
\text { behavior } \\
\text { inde- } \\
\text { pendent of } \\
\text { the } \\
\text { severity of } \\
\text { suicide } \\
\text { risk. }\end{array}$ & $\begin{array}{l}\text { CBT military } \\
\text { personnel } \\
\text { experienced a } 60 \% \\
\text { overall reduction in } \\
\text { suicide attempts. } \\
\text { The study } \\
\text { identified three } \\
\text { (low-severity, } \\
\text { moderate severity, } \\
\text { high severity) } \\
\text { subgroups in the } \\
\text { military personnel } \\
\text { CBT group. TAU } \\
\text { group were } \\
\text { identified as having } \\
\text { low-severity high } \\
\text { suicide attempts } \\
\text { during follow-up. } \\
\text { The researchers } \\
\text { admit limitations in } \\
\text { underestimating the } \\
\text { level of low } \\
\text { severity in TAU. } \\
\text { They also state } \\
\text { more research is } \\
\text { needed to } \\
\text { understand the } \\
\text { different } \\
\text { approaches that } \\
\text { should be used } \\
\text { with subgroups } \\
\text { under the TAU } \\
\text { heading. Overall, } \\
\text { CBT provided } \\
\text { effective } \\
\text { interventions to }\end{array}$ \\
\hline
\end{tabular}




\begin{tabular}{|c|c|c|c|c|c|c|}
\hline & & & & & & $\begin{array}{l}\text { reduce suicide } \\
\text { attempts. }\end{array}$ \\
\hline $\begin{array}{l}\text { Haddock, G., } \\
\text { et al. (2016). } \\
\text { Investigating } \\
\text { the } \\
\text { Feasibility } \\
\text { and } \\
\text { Acceptability } \\
\text { of a } \\
\text { Cognitive } \\
\text { Behavioral } \\
\text { Suicide } \\
\text { Prevention } \\
\text { Therapy for } \\
\text { People in } \\
\text { Acute } \\
\text { Psychiatric } \\
\text { Wards: Study } \\
\text { Protocol for a } \\
\text { Randomized } \\
\text { Controlled } \\
\text { Trial. }\end{array}$ & $\begin{array}{l}\text { RCT, } \\
\text { descriptive, } \\
\text { Level I } \\
\text { Grade A }\end{array}$ & $\begin{array}{l}60, \\
\text { suicidal } \\
\text { within } \\
\text { past } 3 \\
\text { months, } \\
\text { participan } \\
\text { ts } \\
\text { comparin } \\
\text { g CBT- } \\
\text { SP vs. } \\
\text { TAU } \\
\text { acute care } \\
\text { setting. }\end{array}$ & $\begin{array}{l}\text { The Inpatient } \\
\text { Suicide } \\
\text { Intervention } \\
\text { and Therapy } \\
\text { Evaluation } \\
\text { (INSITE) is } \\
\text { the design. } \\
\text { Project ran } \\
\text { over three } \\
\text { phases using } \\
\text { mixed } \\
\text { methods } \\
\text { following the } \\
\text { Medical } \\
\text { Research } \\
\text { Council's } \\
\text { (MRC) } \\
\text { framework. } \\
\text { Recruitment } \\
\text { is over 18- } \\
\text { month period } \\
\text { by trained } \\
\text { research } \\
\text { assistants. } \\
\text { Research } \\
\text { assistants } \\
\text { were blinded } \\
\text { to treatment } \\
\text { allocation } \\
\text { when } \\
\text { conducting } \\
\text { follow-up } \\
\text { visits. } \\
\text { Researchers } \\
\text { used The } \\
\text { Beck Scale } \\
\text { for Suicidal } \\
\text { Ideation; The } \\
\text { Suicidal } \\
\text { Behaviors } \\
\text { Questionnair } \\
\text { e-revised/ } \\
\text { The Suicide } \\
\text { Probability } \\
\text { Scale and 16 } \\
\text { other } \\
\text { assessment } \\
\text { tools at } \\
\text { baseline, } 6 \\
\text { weeks and } 6 \\
\text { months. }\end{array}$ & $\begin{array}{l}\text { No } \\
\text { theoretical } \\
\text { framework } \\
\text { is } \\
\text { documented } \\
\text { in the study; } \\
\text { however, } \\
\text { Beck's } \\
\text { Cognitive } \\
\text { Therapy has } \\
\text { been widely } \\
\text { used in } \\
\text { cases of } \\
\text { depression } \\
\text { and may be } \\
\text { applicable as } \\
\text { a means of } \\
\text { stopping } \\
\text { negative } \\
\text { thoughts } \\
\text { about self, } \\
\text { society and } \\
\text { the future. } \\
\text { The } \\
\text { cognitive } \\
\text { triad occurs } \\
\text { spontan- } \\
\text { eously and } \\
\text { causes } \\
\text { depression. }\end{array}$ & $\begin{array}{l}\text { Outcome } \\
\text { was the } \\
\text { strength of } \\
\text { INSITE } \\
\text { for use } \\
\text { with } \\
\text { inpatient } \\
\text { CBT-SP } \\
\text { in treat- } \\
\text { ment of } \\
\text { high-risk, } \\
\text { acute } \\
\text { inpatient } \\
\text { patients } \\
\text { with } \\
\text { suicide } \\
\text { ideation. }\end{array}$ & $\begin{array}{l}\text { The authors state } \\
\text { further RCT } \\
\text { studies with large } \\
\text { sample size need to } \\
\text { occur. They } \\
\text { suspect there will } \\
\text { be difficulty in } \\
\text { participant } \\
\text { retainment in the } \\
\text { interventions both } \\
\text { with inpatient and } \\
\text { outpatient suicidal } \\
\text { patients. The } \\
\text { authors also admit } \\
\text { a challenge will be } \\
\text { to determine the } \\
\text { most effective and } \\
\text { sensitive measure } \\
\text { to detect } \\
\text { meaningful change } \\
\text { as current } \\
\text { instruments } \\
\text { measuring suicidal } \\
\text { behaviors and } \\
\text { ideation have } \\
\text { limitations. The } \\
\text { authors also } \\
\text { suggest } \\
\text { consideration of } \\
\text { the cost of lengthy } \\
\text { inpatient bed days } \\
\text { needs to be well- } \\
\text { thought-out vs. } \\
\text { traditional } \\
\text { outpatient CBT-SP. }\end{array}$ \\
\hline
\end{tabular}


Systematic Studies/Meta-Analysis

\begin{tabular}{|c|c|c|c|c|c|c|c|}
\hline Citation & $\begin{array}{l}\text { Level of } \\
\text { Evidence } \\
\text { /Quality Grade }\end{array}$ & Question & $\begin{array}{l}\text { Search } \\
\text { Strategy }\end{array}$ & $\begin{array}{l}\text { Inclusion/ } \\
\text { Exclusion } \\
\text { Criteria }\end{array}$ & $\begin{array}{l}\text { Data } \\
\text { Extraction } \\
\text { and } \\
\text { Analysis }\end{array}$ & Key Findings & $\begin{array}{l}\text { Usefulness/R } \\
\text { ecommendati } \\
\text { on/ } \\
\text { Implications }\end{array}$ \\
\hline $\begin{array}{l}\text { Gotzsche, } \\
\text { P.C., } \\
\text { Gotzsche, } \\
\text { P.K. (2017) } \\
\text { Cognitive } \\
\text { Behavioral } \\
\text { Therapy } \\
\text { Haves the } \\
\text { Risk of } \\
\text { Repeated } \\
\text { Suicide } \\
\text { Attempts: A } \\
\text { systematic } \\
\text { Review. } \\
\text { Journal of } \\
\text { The Royal } \\
\text { Society of } \\
\text { Medicine } \\
\text { 110(10), 404- } \\
\text { 410. } \\
\text { Doi.10.1177/ } \\
01410768177 \\
31904\end{array}$ & $\begin{array}{l}\text { Level I-Grade } \\
\text { B due to } 7 / 10 \\
\text { showed a } \\
\text { consistent } \\
\text { effect size in } \\
\text { favor of CBT- } \\
\text { SP. Cochrane } \\
\text { systematic } \\
\text { review. }\end{array}$ & $\begin{array}{l}\text { Does } \\
\text { cognitive } \\
\text { behaviora } \\
1 \text { therapy } \\
\text { decrease } \\
\text { suicide } \\
\text { attempts } \\
\text { in people } \\
\text { with } \\
\text { previous } \\
\text { suicide } \\
\text { attempts? }\end{array}$ & $\begin{array}{l}10 \text { RCT of } \\
\text { CBT-SP with } \\
\text { one trial that } \\
\text { had an } \\
\text { unusually } \\
\text { large effect } \\
\text { that was } \\
\text { excluded } \\
\text { which } \\
\text { decreased the } \\
\text { heterogeneity } \\
\text { in the results. }\end{array}$ & $\begin{array}{l}\text {-inclusion } \\
\text { patients with } \\
\text { any type of } \\
\text { suicide } \\
\text { attempt in } \\
\text { the six } \\
\text { months prior } \\
\text { t trial entry } \\
\text { that resulted } \\
\text { in a clinical } \\
\text { evaluation. } \\
\text {-exclusion } \\
\text { criteria are } \\
\text { other } \\
\text { treatment } \\
\text { modalities } \\
\text { outside of } \\
\text { standard } \\
\text { CBT, } \\
\text { children/ado } \\
\text { lescent }\end{array}$ & $\begin{array}{l}\text { Two } \\
\text { authors } \\
\text { independe } \\
\text { ntly } \\
\text { judged the } \\
\text { eligibility } \\
\text { of trial } \\
\text { and } \\
\text { extracted } \\
\text { data on } \\
\text { both } \\
\text { number of } \\
\text { patients } \\
\text { and } \\
\text { events. } \\
\text { Discussio } \\
\text { n occurred } \\
\text { with } \\
\text { disagreem } \\
\text { ents. 95\% } \\
\text { confidenc } \\
\text { e interval } \\
\text { with risk } \\
\text { ratio. } \\
\text { Odds ratio } \\
\text { also } \\
\text { calculated. } \\
\text { Mantel- } \\
\text { Haenszel } \\
\text { method } \\
\text { was used } \\
\text { for } \\
\text { dichotomo } \\
\text { us data. } \\
\text { Review } \\
\text { Manager, } \\
\text { version } 5 \\
\text { used for } \\
\text { meta- } \\
\text { analysis. }\end{array}$ & $\begin{array}{l}\text { Participants were } \\
\text { randomized into } \\
\text { CBT-SP vs. TAU. } \\
\text { CBT-SP compared } \\
\text { to TAU reduced } \\
\text { the risk of a new } \\
\text { suicide attempt. } \\
\text { Risk ratio } 0.47 ; \\
95 \% \text { confidence } \\
\text { interval } 0.30-0.73 \text {. } \\
p=0.0009 ; 57 \% .\end{array}$ & $\begin{array}{l}\text { CBT-SP vs. } \\
\text { TAU in } \\
\text { patients with } \\
\text { a previous } \\
\text { attempt } \\
\text { halved the } \\
\text { risk in a new } \\
\text { suicide } \\
\text { attempt. If } \\
\text { the TAU } \\
\text { group } \\
\text { received to } \\
\text { treatment, the } \\
\text { effect might } \\
\text { have been } \\
\text { greater. }\end{array}$ \\
\hline $\begin{array}{l}\text { Watts, S., } \\
\text { Turnell, A., } \\
\text { Kladnitski, } \\
\text { N., Newby, } \\
\text { J., Andrews, } \\
\text { G. (2015). }\end{array}$ & $\begin{array}{l}\text { RCT, Level I } \\
\text { Grade B. } \\
\text { Cochrane } \\
\text { systematic } \\
\text { review. This is } \\
\text { a systematic } \\
\text { review that } \\
\text { examines the } \\
\text { impact of TAU }\end{array}$ & $\begin{array}{l}\text { Is CBT } \\
\text { effective } \\
\text { versus } \\
\text { TAU } \\
\text { treating } \\
\text { for } \\
\text { anxiety } \\
\text { and }\end{array}$ & $\begin{array}{l}48 \text { studies of } \\
\text { CBT for } \\
\text { depression or } \\
\text { anxiety of } \\
6,926 \\
\text { participants } \\
\text { and with a } \\
\text { control group }\end{array}$ & $\begin{array}{l}\text {-inclusion } \\
\text { criteria were } \\
\text { all RCTs } \\
\text { with CBT } \\
\text { vs. TAU, } \\
\text { males and } \\
\text { females } 18 \\
\text { years and } \\
\text { above with }\end{array}$ & $\begin{array}{l}\text { Each } \\
\text { study } \\
\text { researcher } \\
\text { s extracted } \\
\text { mean, } \\
\text { standard } \\
\text { deviation } \\
\text { of } \\
\text { participant }\end{array}$ & $\begin{array}{l}\text { Previous reviews } \\
\text { have focused on } \\
\text { examining } \\
\text { comparisons } \\
\text { between CBT-SP } \\
\text { vs. TAU. This } \\
\text { meta-analysis } \\
\text { looked at TAU vs. } \\
\text { Placebo and found }\end{array}$ & $\begin{array}{l}\text { Most studies } \\
\text { were assessed } \\
\text { at low risk of } \\
\text { bias in } \\
\text { random } \\
\text { sequencing. } \\
\text { The overall } \\
\text { effect for } \\
\text { CBT vs. TAS }\end{array}$ \\
\hline
\end{tabular}




$\begin{array}{lll}\text { control } & \text { depressio } & \text { receiving } \\ \text { conditions on } & \mathrm{n} ? & \text { TAU. } \\ \text { the reported } & & \\ \text { treatment } & & \\ \text { effect. } & \end{array}$

Witt, K., et

al. (2018)

RCT, Level I
Grade B.
Cochrane
systematic
review. 18
trials of 2,433
participants
who self-
injured or
intentional drug
overdosed
within six
months.

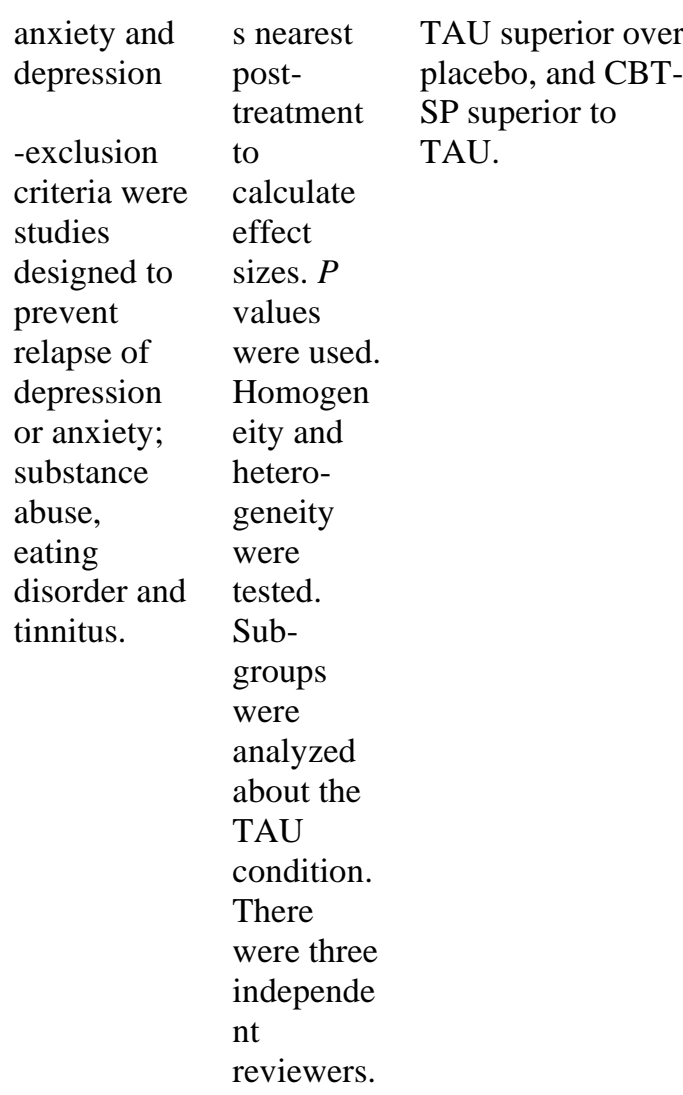

Is CBT
vs. TAU
more
effective
in
reducing
self-
harm?

18 RCT with

-inclusion

criteria

participants.

Five data-

base

CCDANC-

TR-Studies,

CENTRAL,

MEDLINE,

EMBASE

and

PsycINFO

searched

from 1

January 1998

- 30 April

2015.

\begin{tabular}{|c|c|}
\hline $\begin{array}{l}\text { Quantitati } \\
\text { ve data } \\
\text { reflected } \\
\text { repetition } \\
\text { of self- } \\
\text { harm at } \\
\text { six } \\
\text { months, } \\
\text { twelve } \\
\text { months } \\
\text { and final } \\
\text { assess- } \\
\text { ment. } 12 \\
\text { months } \\
\text { was the } \\
\text { last month } \\
\text { and } \\
\text { summariz } \\
\text { ed using } \\
\text { an odds } \\
\text { ratio and } \\
95 \% \\
\text { confidenti } \\
\text { al interval. } \\
\text { Effect size } \\
\text { was used } \\
\text { to } \\
\text { determine }\end{array}$ & $\begin{array}{l}\text { Of the } 2,433 \\
\text { participants } \\
\text { average age was } \\
29.6 ; 1,833 \text { were } \\
\text { female; All partici- } \\
\text { pants engaged in } \\
\text { self-harm within } 6 \\
\text { months of review. } \\
18 \text { trials included } \\
\text { those high-risk for } \\
\text { bias. TAU } \\
\text { described as } a \\
\text { priori ( } 83.3 \%) \\
\text { combining } \\
\text { psychotherapy, } \\
\text { pharmacotherapy, } \\
\text { and referral } \\
\text { services. CBT had } \\
\text { significant } \\
\text { reduction in the } \\
\text { repetition of self- } \\
\text { harm compared to } \\
\text { TAU. }\end{array}$ \\
\hline
\end{tabular}

was

significant favoring CBT over TAU in the treatment of depression and anxiety. Strengths of the reviews was the inclusion of studies that examined different modes of TAU vs. placebo. Limitations were restrictions on publications in English.

TAU most be clearly defined.

Researchers report variations in the quality of the TAU comparator condition between the 18 RCT.

They recommend future trials should provide table to assist in determining the exact detailed breakdown of treatments received by participants.

$\begin{array}{ll}\text { CBT vs. } & 95 \% \\ \text { TAU. } & \begin{array}{l}\text { confidenti } \\ \text { al interval. }\end{array} \\ \text {-exclusion } & \text { Effect size } \\ \text { criteria were } & \text { was used } \\ \text { non-English } & \text { to } \\ \text { studies. } & \text { determine }\end{array}$




\author{
homogene \\ ity and \\ was \\ $>75 \%$. \\ TAU was \\ assessed \\ using a \\ standard \\ pro forma.
}

\begin{tabular}{|c|c|c|c|c|c|c|}
\hline \multicolumn{7}{|c|}{ Effectiveness of Cognitive Behavioral Therapy in Reducing Suicidal Ideation } \\
\hline \multicolumn{7}{|c|}{ Primary Studies } \\
\hline $\begin{array}{l}\text { Brown, G.K., } \\
\text { Have, T.T., } \\
\text { Henriques, } \\
\text { G.R., Xie, } \\
\text { S.X., } \\
\text { Hollander, } \\
\text { J.E., \& Beck, } \\
\text { A.T. (2005). } \\
\text { Cognitive } \\
\text { therapy for } \\
\text { the } \\
\text { prevention of } \\
\text { suicide } \\
\text { attempts: A } \\
\text { randomized } \\
\text { controlled } \\
\text { trial. Journal } \\
\text { of American } \\
\text { Medical } \\
\text { Association, } \\
\text { 294(5), 563- } \\
\text { 570. }\end{array}$ & $\begin{array}{l}\text { RCT, } \\
\text { descriptive, } \\
\text { Level I Grade } \\
\text { B due to RCT } \\
120 \text { partici- } \\
\text { pants and } 18- \\
\text { month } \\
\text { longitudinal } \\
\text { study }\end{array}$ & $\begin{array}{l}120 \mathrm{ED} \\
\text { patients }\end{array}$ & $\begin{array}{l}\text { Research } \\
\text { Tools Used: } \\
\text { 24-item } \\
\text { Hamilton } \\
\text { Rating Scale } \\
\text { for } \\
\text { Depression } \\
\text { (HRSD) and } \\
\text { a self- } \\
\text { reported 21- } \\
\text { item Beck } \\
\text { Depression } \\
\text { Inventory II. } \\
\text { The Suicide } \\
\text { Intent Scale } \\
\text { to determine } \\
\text { suicide } \\
\text { attempt vs. } \\
\text { suicide } \\
\text { gesture. } \\
\text { Random } \\
\text { assignment to } \\
\text { cognitive } \\
\text { therapy } \\
\text { group or } \\
\text { treatment as } \\
\text { usual (TAU) } \\
\text { group. } \\
\text { Single and } \\
\text { multiple } \\
\text { covariate } \\
\text { Cox } \\
\text { proportional } \\
\text { hazard } \\
\text { regression } \\
\text { model to text } \\
\text { for } \\
\text { effectiveness } \\
\text { of suicidal } \\
\text { prevention } \\
\text { interventions. }\end{array}$ & $\begin{array}{l}\text { No } \\
\text { theoretical } \\
\text { framework } \\
\text { is } \\
\text { documented } \\
\text { in the study; } \\
\text { however, } \\
\text { Beck's } \\
\text { Cognitive } \\
\text { Therapy has } \\
\text { been widely } \\
\text { used in } \\
\text { cases of } \\
\text { depression } \\
\text { and may be } \\
\text { applicable as } \\
\text { a means of } \\
\text { correcting } \\
\text { dysfunctiona } \\
\text { l thoughts } \\
\text { and apply } \\
\text { alternative } \\
\text { ways of } \\
\text { thinking. }\end{array}$ & $\begin{array}{l}\text { Outcome } \\
\text { was } \\
\text { cognitive } \\
\text { therapy } \\
\text { was } \\
\text { effective } \\
\text { in } \\
\text { preventing } \\
\text { suicide } \\
\text { attempt in } \\
\text { adults } \\
\text { who } \\
\text { recently } \\
\text { attempted } \\
\text { suicide }\end{array}$ & $\begin{array}{l}\text { Over a 2-year } \\
\text { period, } 350 \\
\text { individuals were } \\
\text { invited to } \\
\text { participate in the } \\
\text { trial. } 230 \text { were } \\
\text { excluded. } 164 \\
\text { (71\% did not meet } \\
\text { inclusion criteria. } \\
66 \text { (27\%) declined } \\
\text { to participate. } 120 \\
\text { participants were } \\
\text { eventually } \\
\text { enrolled. From } \\
\text { baseline to } 18 \\
\text { months, } 13 \\
\text { participants in the } \\
\text { CBT group and } 23 \\
\text { participants in the } \\
\text { TAU group made } 1 \\
\text { attempt of suicide. } \\
\text { Brief CBT is } \\
\text { effective in } \\
\text { reducing suicide } \\
\text { attempts in adults } \\
\text { who have } \\
\text { attempted suicide. } \\
\text { The researchers } \\
\text { determined that } \\
\text { those participants } \\
\text { were } 50 \% \text { less } \\
\text { likely to attempt } \\
\text { suicide during the } \\
\text { follow-up period } \\
\text { that those in the } \\
\text { TAU group. }\end{array}$ \\
\hline $\begin{array}{l}\text { Riblet N., et } \\
\text { al. (2017). }\end{array}$ & $\begin{array}{l}\text { Level III Grade } \\
\text { A. }\end{array}$ & $\begin{array}{l}112 \\
\text { mental }\end{array}$ & $\begin{array}{l}\text { Research } \\
\text { Tools Used: }\end{array}$ & $\begin{array}{l}\text { No } \\
\text { theoretical }\end{array}$ & $\begin{array}{l}\text { Outcome } \\
\text { was }\end{array}$ & $\begin{array}{l}\text { The researchers } \\
\text { identified } 141\end{array}$ \\
\hline
\end{tabular}




\begin{tabular}{|c|c|c|c|c|c|c|}
\hline $\begin{array}{l}\text { Death by } \\
\text { Suicide } \\
\text { Within } 1 \\
\text { Week of } \\
\text { Hospital } \\
\text { Discharge: A } \\
\text { Retrospective } \\
\text { Study of Root } \\
\text { Cause } \\
\text { Analysis } \\
\text { Reports. The } \\
\text { Journal of } \\
\text { Nervous and } \\
\text { Mental } \\
\text { Disease, } \\
\text { 20(6), 436- } \\
442 .\end{array}$ & $\begin{array}{l}\text { Retrospective } \\
\text { RCT study of } \\
\text { RCA reports of } \\
\text { suicidal deaths } \\
\text { within } 7 \text { days } \\
\text { of discharge } \\
\text { from a } \\
\text { Veterans } \\
\text { Health } \\
\text { Administration } \\
\text { (VHA) } \\
\text { hospital. }\end{array}$ & $\begin{array}{l}\text { health } \\
\text { units in } \\
\text { all VHA } \\
\text { facilities } \\
\text { between } \\
2002 \text { and } \\
2015 \\
\text { review of } \\
\text { all RCA } \\
\text { reports of } \\
\text { death by } \\
\text { suicide } \\
\text { within } 7 \\
\text { days of } \\
\text { discharge } \\
\text { of } \\
\text { hospitaliz } \\
\text { ation. }\end{array}$ & $\begin{array}{l}\text { The National } \\
\text { Center for } \\
\text { Patient } \\
\text { Safety } \\
\text { (NCPS) } \\
\text { oversees } \\
\text { VHA safety } \\
\text { efforts and } \\
\text { maintains the } \\
\text { RCA } \\
\text { database. The } \\
\text { researchers } \\
\text { used a } \\
\text { histogram } \\
\text { plot to review } \\
\text { the data of } \\
\text { suicides } \\
\text { within } 7 \text { days } \\
\text { of discharge. } \\
\text { They also } \\
\text { used a } \\
\text { cumulative } \\
\text { frequency } \\
\text { graph, } \\
\text { superimposed } \\
\text { on the plot, to } \\
\text { illustrate the } \\
\text { cumulative } \\
\text { percentage of } \\
\text { deaths by } \\
\text { suicide over } \\
\text { the } 7-\text { day } \\
\text { period. They } \\
\text { evaluated } \\
\text { length of stay } \\
\text { and days to } \\
\text { suicide by } \\
\text { calculating a } \\
\text { Spearman's } \\
\text { rank-order } \\
\text { calculation } \\
\text { (p<0.05 } \\
\text { statistically } \\
\text { significant). }\end{array}$ & $\begin{array}{l}\text { framework } \\
\text { is } \\
\text { documented } \\
\text { in the study; } \\
\text { however, } \\
\text { Beck's } \\
\text { Cognitive } \\
\text { Therapy has } \\
\text { been widely } \\
\text { used in } \\
\text { cases of } \\
\text { depression } \\
\text { and may be } \\
\text { applicable as } \\
\text { a means of } \\
\text { addressing } \\
\text { Negative } \\
\text { self- } \\
\text { schemas. } \\
\text { Depressed } \\
\text { individuals } \\
\text { negative and } \\
\text { pessimistic } \\
\text { beliefs and } \\
\text { expectations } \\
\text { about } \\
\text { themselves. } \\
\text { Beck } \\
\text { believes } \\
\text { negative } \\
\text { schemas are } \\
\text { developed in } \\
\text { childhood as } \\
\text { a result of a } \\
\text { trau- } \\
\text { matic event } \\
\text { (i.e. a death, } \\
\text { parental } \\
\text { rejection or } \\
\text { bullying) }\end{array}$ & $\begin{array}{l}\text { identificat } \\
\text { ion of } \\
\text { high risk } \\
\text { for suicide } \\
\text { in the } \\
\text { week } \\
\text { following } \\
\text { discharge } \\
\text { from acute } \\
\text { inpatient } \\
\text { psychiatri } \\
\text { c unit if } \\
\text { no } \\
\text { interven- } \\
\text { tion for } \\
\text { suicide } \\
\text { prevention } \\
\text { does not } \\
\text { occur } \\
\text { within a } \\
\text { week (7 } \\
\text { days). }\end{array}$ & $\begin{array}{l}\text { deaths by suicide } \\
\text { within } 7 \text { days of } \\
\text { discharge between } \\
\text { afore-mention } \\
\text { dates. } 40 \% \text { within } \\
\text { first day of } \\
\text { discharge. } 67 \% \\
\text { within } 72 \text { hours of } \\
\text { discharge. } 80 \% \\
\text { occurring within } 4 \\
\text { days of discharge. } \\
\text { 118 cases } \\
\text { scheduled to } \\
\text { meeting with } \\
\text { mental health for } \\
\text { outpatient follow- } \\
\text { up. } 50 \% \text { of the } 118 \\
\text { died before the } \\
\text { encounter. } 20 \% \\
\text { were alive but did } \\
\text { not show-up or } \\
\text { cancelled follow- } \\
\text { up. Major gaps in } \\
\text { understanding and } \\
\text { communication. } \\
\text { Perhaps those } \\
\text { discharged and } \\
\text { immediately } \\
\text { commit suicide the } \\
\text { next day should not } \\
\text { have been } \\
\text { discharged. Are } \\
\text { mental health } \\
\text { providers } \\
\text { thoroughly } \\
\text { assessing for } \\
\text { suicide risk at the } \\
\text { time of discharge? } \\
\text { Perhaps recently } \\
\text { discharged suicidal } \\
\text { patients should be } \\
\text { seen before } 7 \text { days. } \\
\text { Are family } \\
\text { involved? And } \\
\text { when no family } \\
\text { available what } \\
\text { social } \\
\text { resources are } \\
\text { available? }\end{array}$ \\
\hline
\end{tabular}




\begin{tabular}{|c|c|c|c|c|c|c|}
\hline Citation & $\begin{array}{l}\text { Level of Question } \\
\text { Evidence } \\
\text { /Quality } \\
\text { Grade }\end{array}$ & Search Strategy & $\begin{array}{l}\text { Inclusion/ } \\
\text { Exclusion } \\
\text { Criteria }\end{array}$ & $\begin{array}{l}\text { Data Extraction } \\
\text { and Analysis }\end{array}$ & Key Findings & $\begin{array}{l}\text { Usefulness/Rec } \\
\text { ommendation/ } \\
\text { Implications }\end{array}$ \\
\hline $\begin{array}{l}\text { Brown, K., } \\
\text { Jager-Hyman, S } \\
\text { (2014). } \\
\text { Evidence-Based } \\
\text { Psychotherapies } \\
\text { for Suicide } \\
\text { Prevention: } \\
\text { Future } \\
\text { Directions. } \\
\text { American } \\
\text { Journal of } \\
\text { Preventive } \\
\text { Medicine, } \\
\text { 47(3S2), S186- } \\
\text { S194. } \\
\text { http://dx.doi.org } \\
\text { /10.106/j.amepr } \\
\text { e.2014.06.008 }\end{array}$ & 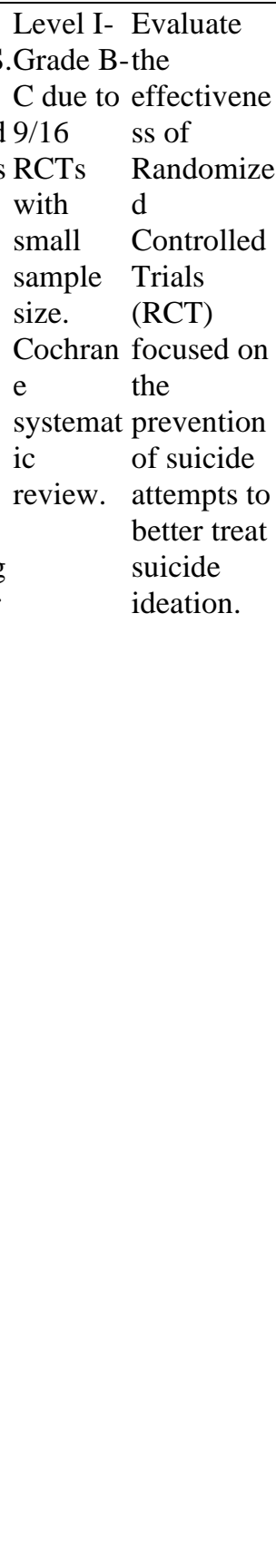 & $\begin{array}{l}\text { Review of } 16 \text { RCT } \\
\text { of CBT-SP, CBT, } \\
\text { dialectical } \\
\text { behavioral therapy } \\
\text { (DBT), problem } \\
\text { solving therapy } \\
\text { (PST), } \\
\text { mentalization- } \\
\text { based therapy } \\
\text { (MBT) and } \\
\text { psychodynamic } \\
\text { inter- personal } \\
\text { therapy (PIT). } \\
\text { MEDLINE, } \\
\text { EMBASE, } \\
\text { PsycINFO } \\
\text { databases and } \\
\text { Cochrane Library. }\end{array}$ & $\begin{array}{l}\text {-inclusion } \\
\text { criteria studies } \\
\text { that were } \\
\text { reported in } \\
\text { English, peer } \\
\text { reviewed } \\
\text { journals. } \\
\text {-exclusion } \\
\text { studies excluded } \\
\text { participants at } \\
\text { imminent risk } \\
\text { for suicide (high } \\
\text { risk). }\end{array}$ & $\begin{array}{l}\text { RCT of CBT } \\
\text { were reviewed } \\
\text { to evaluate the } \\
\text { state of } \\
\text { evidence-based } \\
\text { treatment for } \\
\text { suicide } \\
\text { prevention vs. } \\
\text { TAU. } \\
\text { Psychotherapy } \\
\text { treatments } \\
\text { directly targeted } \\
\text { to suicidal } \\
\text { ideation were } \\
\text { most successful } \\
\text { in suicide } \\
\text { prevention. } \\
\text { Collaborative } \\
\text { Assessment and } \\
\text { Management of } \\
\text { suicidality } \\
\text { (CAMS), CBT, } \\
\text { PST and IT } \\
\text { resulted in the } \\
\text { reduction of } \\
\text { suicide ideation } \\
\text { in adults. }\end{array}$ & $\begin{array}{l}\text { Recent suicide } \\
\text { attempters who } \\
\text { received CBT-SP } \\
\text { were } 50 \% \text { less } \\
\text { likely to reattempt } \\
\text { than participants } \\
\text { who received } \\
\text { TAU. CBT and } \\
\text { TAU which } \\
\text { included enhanced } \\
\text { tracking and } \\
\text { referral care } \\
\text { decreased suicide } \\
\text { attempts with } \\
\text { borderline } \\
\text { personality } \\
\text { disorder. }\end{array}$ & $\begin{array}{l}\text { Gaps and } \\
\text { methodology } \\
\text { concerns were } \\
\text { identified in } \\
\text { RCT literature. } \\
\text { Reviewers } \\
\text { were unable to } \\
\text { determine } \\
\text { whether death } \\
\text { by suicide } \\
\text { (rather than } \\
\text { suicide } \\
\text { attempts) can } \\
\text { be prevented } \\
\text { by } \\
\text { psychotherapy. } \\
\text { Reviewers } \\
\text { were unable to } \\
\text { determine if } \\
\text { interventions } \\
\text { were } \\
\text { successful for } \\
\text { both low and } \\
\text { high-risk } \\
\text { patients due to } \\
\text { exclusion of } \\
\text { high-risk } \\
\text { patients. } \\
\text { Populations } \\
\text { and sample } \\
\text { size should } \\
\text { include older } \\
\text { adults, } \\
\text { Veterans, } \\
\text { LGBTQ2, and } \\
\text { other minority- } \\
\text { ties. Focus was } \\
\text { on outpatient } \\
\text { interventions, } \\
\text { few RCTs } \\
\text { conducted in } \\
\text { acute care } \\
\text { settings. }\end{array}$ \\
\hline $\begin{array}{l}\text { Calati, R., } \\
\text { Courtet, P. } \\
\text { (2016). Is } \\
\text { Psychotherapy } \\
\text { Effective for } \\
\text { Reducing } \\
\text { Suicide } \\
\text { Attempts and }\end{array}$ & $\begin{array}{l}\text { Level II Evaluate } \\
\text { Grade A the } \\
\text { included effectivene } \\
32 \text { RCTs ss of } \\
\text { for a psycho- } \\
\text { total of therapy to } \\
4,114 \text { reduce } \\
\text { patients incidents of }\end{array}$ & $\begin{array}{l}\text { Medical literature } \\
\text { search regarding } \\
\text { interventions to } \\
\text { review randomized } \\
\text { controlled trials } \\
\text { comparing } \\
\text { psychotherapy to } \\
\text { ftreatment as usual }\end{array}$ & $\begin{array}{l}\text {-inclusion must } \\
\text { be published in } \\
\text { a peer-reviewed } \\
\text { ljournal, written } \\
\text { in English, } \\
\text { RCTs and } \\
\text { compare a form } \\
\text { of }\end{array}$ & $\begin{array}{l}\text { Data were } \\
\text { screened by two } \\
\text { reviewers. } \\
\text { Disagreements } \\
\text { were solved by } \\
\text { discussion. } \\
\text { Each RCT were } \\
\text { evaluated for }\end{array}$ & $\begin{array}{l}\text { Patients who } \\
\text { received CBT } \\
\text { were less likely to } \\
\text { attempt suicide in } \\
\text { comparison with } \\
\text { patients in the } \\
\text { TAU enrolled } \\
\text { group. Significant }\end{array}$ & $\begin{array}{l}\text { The NSSI } \\
\text { sample size } \\
\text { was small and } \\
\text { there was the } \\
\text { feeling that } \\
\text { publication } \\
\text { bias may have } \\
\text { contributed to }\end{array}$ \\
\hline
\end{tabular}




\begin{tabular}{|c|c|c|c|c|c|c|}
\hline Citation & $\begin{array}{l}\text { Level of Question } \\
\text { Evidence } \\
\text { /Quality } \\
\text { Grade }\end{array}$ & Search Strategy & $\begin{array}{l}\text { Inclusion/ } \\
\text { Exclusion } \\
\text { Criteria }\end{array}$ & $\begin{array}{l}\text { Data Extraction } \\
\text { and Analysis }\end{array}$ & Key Findings & $\begin{array}{l}\text { Usefulness/Rec } \\
\text { ommendation/ } \\
\text { Implications }\end{array}$ \\
\hline $\begin{array}{l}\text { Non-Suicidal } \\
\text { Self-Injury } \\
\text { Rates? Meta- } \\
\text { Analysis and } \\
\text { Meta- } \\
\text { Regression of } \\
\text { Literature Data. } \\
\text { Journal of } \\
\text { Psychiatric } \\
\text { Research,79, 8- } \\
20 .\end{array}$ & $\begin{array}{l}\text { randoml suicide } \\
\text { y attempts or } \\
\text { assigned non- } \\
\text { to either suicidal } \\
\text { psychoth self-injury. } \\
\text { erapy or } \\
\text { TAU. } \\
\text { Cochran } \\
\text { e } \\
\text { systemat } \\
\text { ic } \\
\text { review. }\end{array}$ & $\begin{array}{l}\text { (TAU). } \\
\text { MEDLINE, } \\
\text { EMBASE, } \\
\text { PsycINFO } \\
\text { databases and } \\
\text { Cochrane Library. }\end{array}$ & $\begin{array}{l}\text { psychotherapy } \\
\text { interventions } \\
\text { with TAU to } \\
\text { include } \\
\text { community } \\
\text { referral for } \\
\text { ongoing clinical } \\
\text { monitoring. } \\
\text {-exclusion if } \\
\text { studies were } \\
\text { performed on } \\
\text { overlapping } \\
\text { samples, } \\
\text { focused on } \\
\text { interventions } \\
\text { that did not } \\
\text { involve patients } \\
\text { combined } \\
\text { suicide attempt } \\
\text { (SA) and non- } \\
\text { suicidal self- } \\
\text { injury (NSSI). }\end{array}$ & $\begin{array}{l}\text { treatment, total } \\
\text { sample size, } \\
\text { percentage of } \\
\text { females, mean } \\
\text { age, diagnosis, } \\
\text { assessment of } \\
\text { medications, } \\
\text { duration of } \\
\text { psychotherapeut } \\
\text { ic treatment, } \\
\text { number of } \\
\text { weekly sessions, } \\
\text { duration of } \\
\text { follow-up, main } \\
\text { scales used for } \\
\text { the assessment } \\
\text { and main } \\
\text {; results. The } \\
\text { Jadad scale was } \\
\text { used to monitor } \\
\text { quality of } \\
\text { reporting. } \\
\text { Cochrane Risk } \\
\text { of Bias Tool } \\
\text { also used. } \\
\text { Cochrane } \\
\text { Collaboration } \\
\text { Review } \\
\text { Manager } \\
\text { software used to } \\
\text { enter data and } \\
\text { analyze risk } \\
\text { differences } \\
\text { associated } 95 \% \\
\text { confidence } \\
\text { intervals (CI) } \\
\text { were calculated. }\end{array}$ & $\begin{array}{l}\text { results were found } \\
\text { overall in the CBT } \\
\text { group. The NSSI } \\
\text { trials were eight. } \\
\text { There were no } \\
\text { significant } \\
\text { findings in the } \\
\text { NSSI CBT vs. } \\
\text { t TAU group during } \\
\text { the follow-up } \\
\text { period. The } \\
\text {,researchers found } \\
\text { CBT was effective } \\
\text { with outpatients } \\
\text { and not inpatients. }\end{array}$ & $\begin{array}{l}\text { incomplete/inc } \\
\text { orrect data } \\
\text { collection. } \\
\text { Longer follow- } \\
\text { up studies } \\
\text { would generate } \\
\text { a more reliable } \\
\text { meta-analysis. }\end{array}$ \\
\hline
\end{tabular}

Ghahramanlou- RCT, Can CBT- 16 RCT of CBT -inclusion must In addition to CBT-SP initiated There is a lack Holloway, M., Level II SP (Brown-Jager- be published in the RCT of CBTon the inpatient of knowledge et al. (2015). Grade B specifically Hyman) 28 RCT a peer-reviewed with focus on setting is effective above CBT-SP Inpatient Post- of CBT (Tarrier, et journal, written PACT, the Cognitive Admission al.,) 3 inpatient in English, authors $\begin{array}{llll}\text { Behavior } & \text { Cognitive } & \text { RCT of CBT-SP. } & \text { RCTs and conducted a } \\ \text { Therapy } & \text { Therapy } & \text { MEDLINE, } & \text { compare a form search of the }\end{array}$

Therapy

Approaches for

Suicide

Prevention.

Current

Treatment

Options

Psychiatry, 2; (PACT) be EMBASE, adapted for PsycINFO of psychotherapy use in databases and interventions psychiatric Cochrane Library. with TAU to inpatient settings? include community referral for National Institutes of Health RePORTER to primary mental find unpublishedhealth diagnosis studies of inpatient CBT- conditions. with high-risk as an effective patients as a meanstreatment for of directly suicide in the targeting suicidal inpatient acute thoughts and care settings. behaviors in This gap is due to lack of targeted suicidal interventions while 


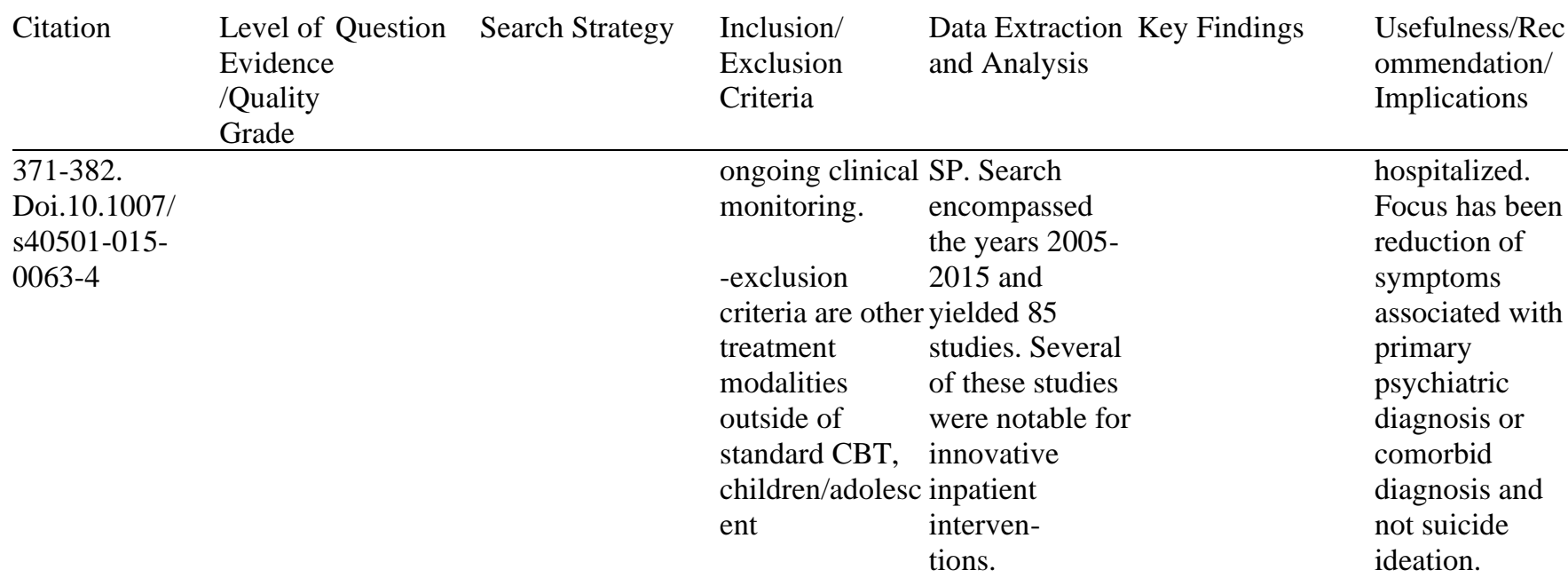

Metwon, L., RCT, What is the 15 RCT of CBT.

Andrews, G. Level II- Effectivene The studies were

(2016).

Cognitive

Behavioral

Therapy for

Suicidal

Behaviors:

Improving

Patient

Outcomes.

Journal of

Psychology

Research and

Behavior

Management, 9,

21-29.
Grade B ss of CBT taken from

due to on Suicide PsycINFO

7/15 Cognition database and

with and Suicidevarious other

small Behaviors public lists. The

sample vs. mental researchers were

size illness? looking at suicidal

which cognitions and

produced

a small

effect

size ,

(1)

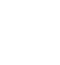

(n)

-inclusion ClinTools The researchers The

criteria studies Software was found CBT is less researchers did that were used to calculate effective when not conduct a reported in data for studies used to treat quality English, peer that did not mental illness. evaluation. reviewed report effect The researchers The sample journals. sizes and determined CBT is size was small confidence effective first line and many of $\begin{array}{lll}\text {-exclusion intervals. Forest treatment of } & \text { the studies did } \\ \text { criteria are other plot of the effect suicidal cognition } & \text { not include the }\end{array}$ treatment size (Cohen's d) and suicidal severity of modalities was used to behaviors. suicidality. outside of calculate a constandard CBT, fidence interval children/adolesc of $95 \%$. Three

ent of the 15 studies

had a control

group the

remain 12

studies had

TAU.

\begin{tabular}{|c|c|c|c|c|c|c|c|}
\hline $\begin{array}{l}\text { arrier, N., } \\
\text { aylor, K., } \\
\text { tooding, P. } \\
\text { 2008). } \\
\text { ognitive- } \\
\text { ehavioral } \\
\text { terventions to } \\
\text { educe Suicide } \\
\text { ehavior. } \\
\text { ournal of } \\
\text { ehavior } \\
\text { lodification, } \\
\text { 2(1), 77-107. }\end{array}$ & $\begin{array}{l}\text { RCT, } \\
\text { Level II } \\
\text { Grade B } \\
\text { due to } \\
18 / 28 \\
\text { studies } \\
\text { with a } \\
\text { small } \\
\text { sample } \\
\text { size and } \\
\text { variation } \\
\text { in the } \\
\text { quality } \\
\text { of trial } \\
\text { metho- } \\
\text { dology }\end{array}$ & $\begin{array}{l}\text { Can CBT } \\
\text { interventio } \\
\text { ns reduce } \\
\text { suicide } \\
\text { behavior v } \\
\text { TAU? }\end{array}$ & $\begin{array}{l}28 \text { RCT of CBT. } \\
\text { PsychINFO and } \\
\text { Web of Science } \\
\text { database search } \\
\text { sfrom 1980. Also, } \\
\text { hand search of } \\
\text { articles from } \\
\text { Journal of } \\
\text { Psychiatry, } \\
\text { Behavioral and } \\
\text { Cognitive Psycho- } \\
\text { therapy, } \\
\text { Behavioral } \\
\text { Research and } \\
\text { Therapy and } \\
\text { relevant journals. }\end{array}$ & $\begin{array}{l}\text {-inclusion } \\
\text { published in a } \\
\text { refereed journal } \\
\text { and included a } \\
\text { treatment group } \\
\text { of CBT. } \\
\text { Control group of } \\
\text { TAU or no } \\
\text { treatment. }\end{array}$ & $\begin{array}{l}\text { The Clinical } \\
\text { Trials } \\
\text { Assessment } \\
\text { Measure } \\
\text { (CTAM) for } \\
\text { quality of } \\
\text { fpsychological } \\
\text { treatment, } \\
\text { CONSORT } \\
\text { guidelines and } \\
\text { expert opinion } \\
\text { resulted in 15 } \\
\text { items grouped } \\
\text { into six area of } \\
\text { trial design. } \\
\text { CTAM showed } \\
\text { blind interrater }\end{array}$ & $\begin{array}{l}\text { dies } \\
\text { d CBT but } \\
\text { in } \\
\text { ntion } \\
\text { ls and } \\
\text { nt } \\
\text { ues. Some } \\
\text { offered } \\
\text { red/ } \\
\text { dized } \\
\text { ns while in } \\
\text { udies } \\
\text { ntion } \\
\text { s were } \\
\text { ped. } \\
\text { ive therapy } \\
\text { ide }\end{array}$ & $\begin{array}{l}\text { Overall } \\
\text { hypothesis was } \\
\text { CBT could } \\
\text { reduce suicide } \\
\text { behavior was } \\
\text { strongly } \\
\text { supported by } \\
\text { the meta- } \\
\text { analysis. CBT- } \\
\text { SP appeared } \\
\text { effective with } \\
\text { adults but no } \\
\text { with } \\
\text { adolescents. } \\
\text { CBT is more } \\
\text { effective when } \\
\text { compared to }\end{array}$ \\
\hline
\end{tabular}




\begin{tabular}{|c|c|c|c|c|c|c|}
\hline Citation & $\begin{array}{l}\text { Level of Question } \\
\text { Evidence } \\
\text { /Quality } \\
\text { Grade }\end{array}$ & Search Strategy & $\begin{array}{l}\text { Inclusion/ } \\
\text { Exclusion } \\
\text { Criteria }\end{array}$ & $\begin{array}{l}\text { Data Extraction } \\
\text { and Analysis }\end{array}$ & Key Findings & $\begin{array}{l}\text { Usefulness/Rec } \\
\text { ommendation/ } \\
\text { Implications }\end{array}$ \\
\hline & & & $\begin{array}{l}\text { not include a } \\
\text { CBT or TAU } \\
\text { group. Also } \\
\text { excluded if } \\
\text { published before } \\
1980 \text { and not in } \\
\text { English. }\end{array}$ & $\begin{array}{l}\text { agreement }(.96) \\
\text { and excellent } \\
\text { validity. }\end{array}$ & $\begin{array}{l}\text { prevention was a } \\
\text { major treatment } \\
\text { component in the } \\
\text { majority of the } \\
\text { studies. }\end{array}$ & $\begin{array}{l}\text { TAU. CBT } \\
\text { more effective } \\
\text { when focused } \\
\text { on reducing } \\
\text { suicide } \\
\text { behavior. Less } \\
\text { effective when } \\
\text { focused on } \\
\text { other mental } \\
\text { health } \\
\text { symptoms (i.e. } \\
\text { depression or } \\
\text { distress). }\end{array}$ \\
\hline
\end{tabular}

Effectiveness of Cognitive Behavioral Therapy in Reducing Suicidal Ideation in the Veteran Population Primary Studies

\begin{tabular}{|c|c|c|c|c|c|c|}
\hline \multirow[b]{2}{*}{ Citation } & \multicolumn{5}{|c|}{ Intervention } & \multirow[b]{2}{*}{$\begin{array}{l}\text { Usefulness } \\
\text { Results } \\
\text { Key Findings }\end{array}$} \\
\hline & $\begin{array}{l}\text { Design, } \\
\text { Level } \\
\text { Quality } \\
\text { Grade }\end{array}$ & $\begin{array}{l}\text { Sample } \\
\text { Sample } \\
\text { size }\end{array}$ & $\begin{array}{l}\text { Comparison } \\
\text { (Definitions } \\
\text { should include } \\
\text { any specific } \\
\text { research tools } \\
\text { used along } \\
\text { with reliability } \\
\& \text { validity) }\end{array}$ & $\begin{array}{l}\text { Theoretical } \\
\text { Foundation }\end{array}$ & $\begin{array}{l}\text { Outcome } \\
\text { Definition }\end{array}$ & \\
\hline $\begin{array}{l}\text { Brown, et al. } \\
(2016) \text {. } \\
\text { Effectiveness } \\
\text { of Cognitive } \\
\text { Behavioral } \\
\text { Therapy with } \\
\text { Depression } \\
\text { and Suicidal } \\
\text { Ideation. } \\
\text { Archives of } \\
\text { Suicide } \\
\text { Research, 20: } \\
677-682 \text {. } \\
\text { Doi:10.1080/ } \\
\text { 1381118 } \\
2016.116223 \\
8\end{array}$ & $\begin{array}{l}\text { Level III } \\
\text { Grade C. } \\
\text { VA } \\
\text { medical } \\
\text { center and } \\
\text { commu- } \\
\text { nity based } \\
\text { outpatient } \\
\text { VA clinic } \\
\text { training } \\
\text { program. }\end{array}$ & $\begin{array}{l}902 \\
\text { Veterans } \\
\text { participat } \\
\text { ed in a } \\
\text { Training } \\
\text { Program } \\
\text { using } \\
\text { Beck } \\
\text { Depressio } \\
\mathrm{n} \\
\text { Inventory } \\
\text {-II (BDI- } \\
\text { II) scale } \\
\text { to assess } \\
\text { severity } \\
\text { of } \\
\text { depressio } \\
\mathrm{n} \text { and } \\
\text { suicide } \\
\text { ideation. }\end{array}$ & $\begin{array}{l}\text { BDI-II and } \\
\text { suicide } \\
\text { ideation scores } \\
\text { were used at } \\
\text { baseline, } \\
\text { seventh } \\
\text { session and } \\
\text { final tenth } \\
\text { session. An } \\
\text { additional } \\
\text { intent-to-treat } \\
\text { (ITT) analysis } \\
\text { of the effect of } \\
\text { baseline } \\
\text { suicide } \\
\text { ideations was } \\
\text { implemented. } \\
\text { ITT analysis } \\
\text { change was } \\
\text { limited to } 882 \\
\text { patients with } \\
\text { at least one } \\
\text { data point } \\
\text { indicating } \\
\text { suicide }\end{array}$ & $\begin{array}{l}\text { No theoretical } \\
\text { framework is } \\
\text { documented in } \\
\text { the study; } \\
\text { however, } \\
\text { Beck's } \\
\text { Cognitive } \\
\text { Therapy has } \\
\text { been widely } \\
\text { used in cases } \\
\text { of depression } \\
\text { and may be } \\
\text { applicable as a } \\
\text { means of } \\
\text { correcting } \\
\text { dysfunctional } \\
\text { thoughts and } \\
\text { apply } \\
\text { alternative } \\
\text { ways of } \\
\text { thinking. }\end{array}$ & $\begin{array}{l}\text { Half of the } \\
\text { Veterans } \\
\text { receiving } \\
\text { CBT for } \\
\text { depression } \\
\text { and suicide } \\
\text { ideation } \\
\text { reported a } \\
\text { clinical } \\
\text { reduction in } \\
\text { suicide } \\
\text { ideation in } \\
\text { 64\% from } \\
\text { baseline to } \\
\text { final } \\
\text { assessment. } \\
\text { Further } \\
\text { findings } \\
\text { indicated } \\
\text { consistent } \\
\text { reduction in } \\
\text { the severity } \\
\text { of suicide } \\
\text { ideation. }\end{array}$ & $\begin{array}{l}\text { Limitations are the } \\
\text { Veterans were from a } \\
\text { sample of patients } \\
\text { receiving treatment in a } \\
\text { Training Program and not a } \\
\text { RCT. The evaluations } \\
\text { were not conducted by } \\
\text { those trained in CBT. }\end{array}$ \\
\hline
\end{tabular}




\begin{tabular}{|c|c|c|c|c|c|c|}
\hline & & & $\begin{array}{l}\text { ideation. Of } \\
\text { the } 882 \\
\text { patients } 463 \\
\text { had suicide } \\
\text { ideation at all } \\
\text { three data } \\
\text { points. }\end{array}$ & & & \\
\hline $\begin{array}{l}\text { Bryan, C., } \\
\text { Rozek, D., } \\
\text { Butner, J., } \\
\text { Rudd, M.D. } \\
\text { (2019). } \\
\text { Patterns of } \\
\text { change in } \\
\text { suicide } \\
\text { ideation } \\
\text { signal the re- } \\
\text { currence of } \\
\text { suicide } \\
\text { attempts } \\
\text { among high- } \\
\text { risk } \\
\text { psychiatric } \\
\text { out- } \\
\text { patients. }\end{array}$ & $\begin{array}{l}\text { RCT, } \\
\text { Level III } \\
\text { Grade B. } \\
\text { There were } \\
33 \text { in the } \\
\text { sub- group } \\
\text { of high- } \\
\text { risk, repeat } \\
\text { military } \\
\text { suicide } \\
\text { assigned to } \\
\text { receive } \\
\text { Brief CBT. } \\
29 \text { men/4 } \\
\text { women } 19- \\
44 \text { years of } \\
\text { age. }\end{array}$ & $\begin{array}{l}152 \text { who } \\
\text { met } \\
\text { criteria } \\
(\mathrm{n}=76 \\
\text { Brief } \\
\text { CBT and } \\
\mathrm{n}=76 \\
\text { TAU). } \\
\text { Only } 33 \\
\text { were } \\
\text { assigned } \\
\text { to receive } \\
\text { interventi } \\
\text { ons. }\end{array}$ & $\begin{array}{l}33 \text { were } \\
\text { randomized } \\
\text { into either } \\
\text { BCBT or TAU } \\
\text { using } \\
\text { computerized } \\
\text { algorithm. } \\
\text { Assessments } \\
\text { at } 3,6,12,18 \\
\text { and } 24 \text { months } \\
\text { postbaseline. } \\
\text { CONSORT } \\
\text { chart, self- } \\
\text { report scale of } \\
\text { the Beck Dep- } \\
\text { ression } \\
\text { Inventory for } \\
\text { SI. Suicide } \\
\text { attempts } \\
\text { assessed using } \\
\text { Suicide } \\
\text { Attempt Self } \\
\text { Injury } \\
\text { Interview } \\
\text { (SASII). }\end{array}$ & $\begin{array}{l}\text { No theoretical } \\
\text { framework is } \\
\text { documented in } \\
\text { the study; } \\
\text { however, } \\
\text { Beck's } \\
\text { Cognitive } \\
\text { Therapy has } \\
\text { been widely } \\
\text { used in cases } \\
\text { of depression } \\
\text { and may be } \\
\text { applicable as a } \\
\text { means of } \\
\text { correcting } \\
\text { dysfunctional } \\
\text { thoughts and } \\
\text { apply } \\
\text { alternative } \\
\text { ways of } \\
\text { thinking. }\end{array}$ & $\begin{array}{l}\text { Outcome was } \\
\text { cognitive } \\
\text { therapy was } \\
\text { effective in } \\
\text { preventing } \\
\text { suicide } \\
\text { attempt in } \\
\text { adults who } \\
\text { recently } \\
\text { attempted } \\
\text { suicide. }\end{array}$ & $\begin{array}{l}\text { Researchers found the } \\
\text { severity of suicide ideation } \\
\text { was limited and variable in } \\
\text { determining when patients } \\
\text { are most likely to engage } \\
\text { in suicidal behavior. They } \\
\text { deter- mined this was due } \\
\text { to the non-linear and } \\
\text { dynamic risk of suicide } \\
\text { rick behavior. The } \\
\text { summation was that CBT- } \\
\text { SP outperform comparison } \\
\text { treatments due to the non- } \\
\text { linear, variable centered } \\
\text { and fluid vulnerability for } \\
\text { recurrent suicide. }\end{array}$ \\
\hline $\begin{array}{l}\text { Rudd M.D., } \\
\text { et al. (2015). } \\
\text { Brief } \\
\text { Cognitive- } \\
\text { Behavioral } \\
\text { Therapy } \\
\text { Effects on } \\
\text { Post- } \\
\text { Treatment } \\
\text { Suicide } \\
\text { Attempts in a } \\
\text { Military } \\
\text { Sample: } \\
\text { Results of a } \\
\text { Randomized } \\
\text { Clinical Trial } \\
\text { with 2-Year } \\
\text { Follow-up. } \\
\text { American } \\
\text { Journal of }\end{array}$ & $\begin{array}{l}\text { RCT, } \\
\text { descriptive } \\
\text {, Level I } \\
\text { Grade A } \\
\text { due to a 2- } \\
\text { year } \\
\text { longitu- } \\
\text { dinal } \\
\text { study. }\end{array}$ & $\begin{array}{l}152 \\
\text { partici- } \\
\text { pants. } 76 \\
\text { randomiz } \\
\text { ed to } \\
\text { TAU with } \\
\text { brief CBT } \\
\text { group and } \\
76 \\
\text { participan } \\
\text { ts } \\
\text { randomiz } \\
\text { ed to } \\
\text { Treatment } \\
\text { as Usual } \\
\text { (TAU) } \\
\text { group. }\end{array}$ & $\begin{array}{l}\text { Research } \\
\text { Tools Used: } \\
\text { The Suicide } \\
\text { Attempt Self- } \\
\text { Injury } \\
\text { Interview and } \\
\text { the Beck Scale } \\
\text { for Suicide } \\
\text { Ideation was } \\
\text { used to } \\
\text { determine the } \\
\text { occurrence of } \\
\text { suicide } \\
\text { attempts and } \\
\text { presence of } \\
\text { suicide } \\
\text { ideation. The } \\
\text { researchers } \\
\text { used a } \\
\text { software }\end{array}$ & $\begin{array}{l}\text { No theoretical } \\
\text { framework is } \\
\text { documented in } \\
\text { the study; } \\
\text { however, } \\
\text { Beck's } \\
\text { Cognitive } \\
\text { Therapy has } \\
\text { been widely } \\
\text { used in cases } \\
\text { of depression } \\
\text { and may be } \\
\text { applicable as a } \\
\text { way of } \\
\text { rectifying } \\
\text { errors in logic } \\
\text { (distortion of } \\
\text { thought } \\
\text { processes) } \\
\text { which are self- }\end{array}$ & $\begin{array}{l}\text { Outcome was } \\
\text { brief CBT } \\
\text { was effective } \\
\text { in preventing } \\
\text { follow-up } \\
\text { suicide } \\
\text { attempts } \\
\text { among active } \\
\text { duty military } \\
\text { members who } \\
\text { had current } \\
\text { suicide } \\
\text { ideation and } \\
\text { or recent } \\
\text { suicide } \\
\text { attempts. }\end{array}$ & $\begin{array}{l}31 \text { suicide attempts were } \\
\text { made by } 26 \text { participants in } \\
\text { both groups during the } 2- \\
\text { year follow-up timeframe. } \\
\text { There were } 2 \text { suicide } \\
\text { deaths during this time. } \\
\text { Data showed military } \\
\text { personnel who were in } \\
\text { TAU with brief CBT were } \\
60 \% \text { less likely to attempt } \\
\text { suicide than those who } \\
\text { were TAU. Limitations } \\
\text { were the sample size was } \\
\text { comprised of active-duty } \\
\text { military personnel and did } \\
\text { not include those recently } \\
\text { discharged from military } \\
\text { service. Sample was } \\
\text { predominately male. }\end{array}$ \\
\hline
\end{tabular}


Psychiatry,

172(5), 441-

449.

\author{
SAS9.3 (SAS defeating and \\ Institute, Cary, can cause \\ N.C.). To anxiety and \\ determine the depression. \\ effectiveness \\ of brief CBT \\ vs. TAU, \\ univariate and \\ multivariate \\ Cox \\ proportional \\ hazard \\ regression \\ models were \\ used.
}




\section{Appendix C}

SWOT Analysis of Organization

\section{STRENTGHS}

1. Highly established positive reputation teaching hospital with comprehensive Veteran programs

2. Dual appointment physicians and clinical staff

3. Multiple satellite locations

4. Not -for-profit model of care

5. Building state of the art bed-tower

6. Low staff turnover

7. Supportive of education and evidence-based research

8. Conducts a large volume of research

9. Excellent patient care as demonstrated by patient survey and patient outcomes

\section{WEAKNESSES}

1. Protracted HR process for onboarding of new hires

2. VHA Directives that are required to be adopted by all VA hospitals even if not an appropriate "fit"

3. Budget set by Congress

4. The patient electronic medical record

5. Inflexibility of staffing schedules

\section{OPPORTUNITIES}

\section{THREATS}

1. Opportunities to improve (OTI) patient care outcomes in chronic care settings

2. OTI the patient electronic medical record

3. Update current technology
1. Pay scale not always comparable to private sector narrowing qualified job applicants

2. Educational funding has been severely cut

3. Technology often outdated 


\section{Appendix D}

Brainstorming Tool to Identify Stakeholders

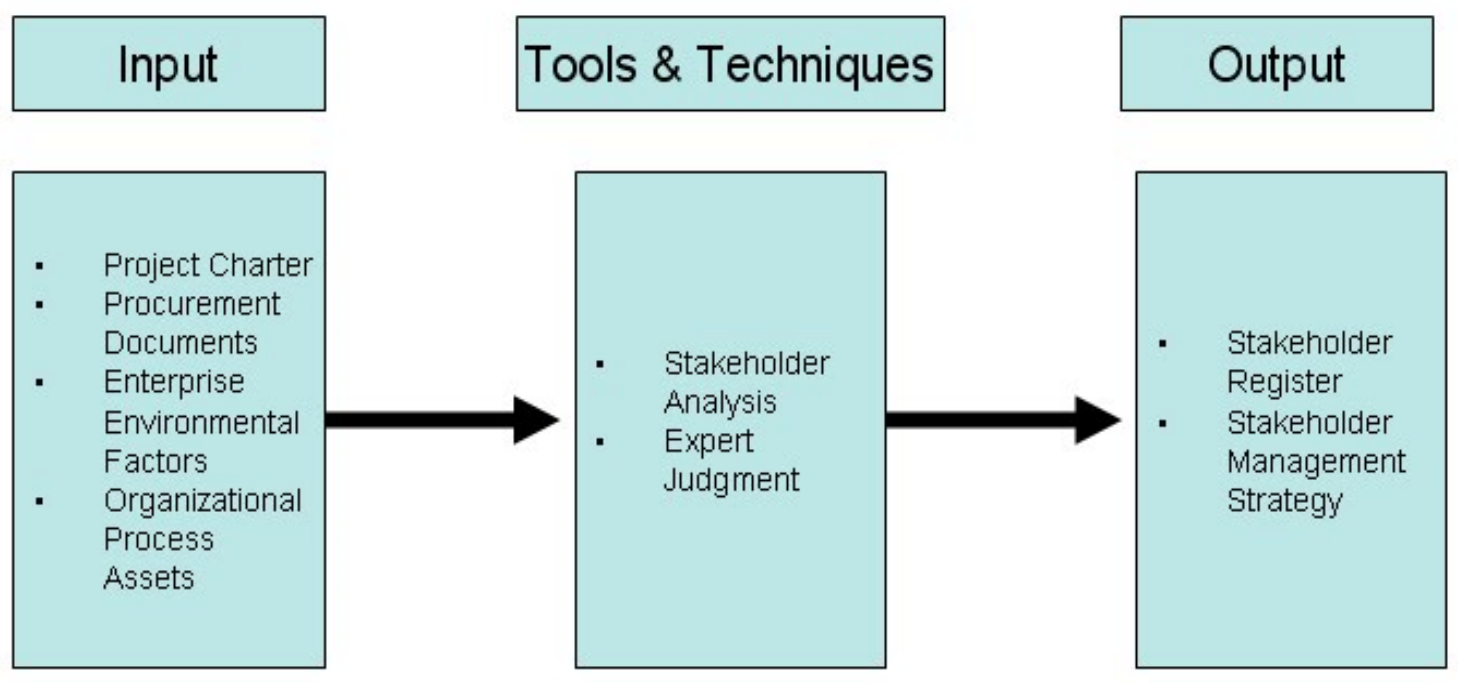




\section{Appendix E}

\section{Gantt Timeline Chart}

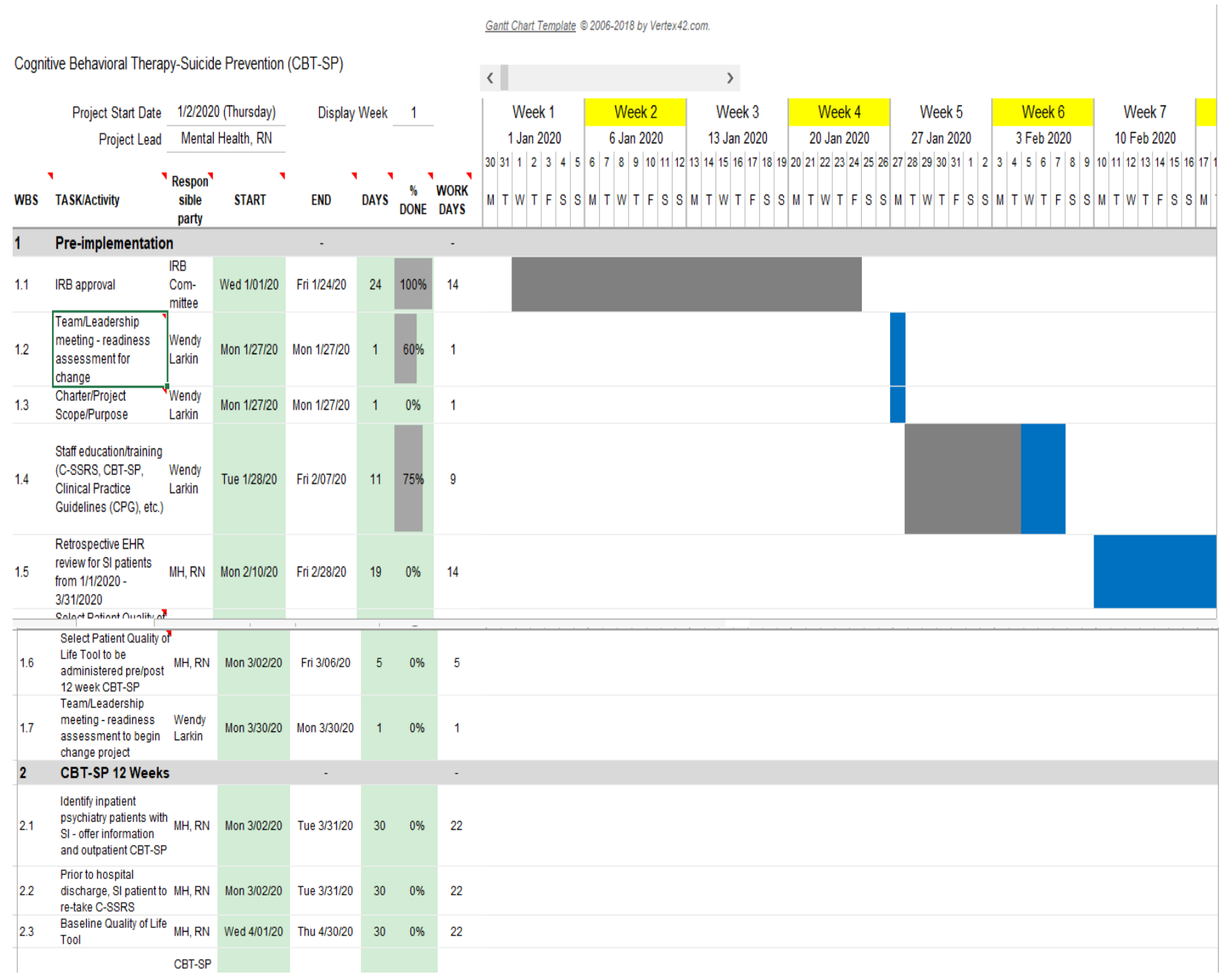




\section{Appendix F}

\section{Metric Matrix}

\begin{tabular}{|c|c|c|c|c|c|c|c|c|}
\hline MEASURES & & & TEGORIES & & & TIME for DATA CO & LLECTION & \\
\hline $\begin{array}{l}\text { Wendy|D. Larkin, MSN, ARNP } \\
\text { Cognitive Behavioral Therapy - Suicide } \\
\text { Prevention (CBT-SP) IPE7230 }\end{array}$ & OUTCOME & PROCESS & BALANCING & FINANCIAL & $\begin{array}{l}\text { Baseline - Psychiatric } \\
\text { Inpatient Admission (7-14 } \\
\text { inpatient days) } \\
\end{array}$ & CBT-SP 30 days & CBT-SP 60 days & CBT-SP 90 days \\
\hline $\begin{array}{l}\text { Baseline data will be collected three } \\
\text { months retrospective }(1 / 2020-3 / 31 / 2020) \\
\text { to review patients who did not receive CBT- } \\
\text { SP, versus a three month prospective data } \\
\text { review of patients who did received CBT-SP } \\
(7 / 2020-9 / 2020)\end{array}$ & & & & & Baseline retrospective data & \begin{tabular}{|l|} 
Monthly \\
retrospective review
\end{tabular} & $\begin{array}{l}\text { Monthly } \\
\text { retrospective review }\end{array}$ & $\begin{array}{l}\text { Monthly } \\
\text { retrospective review }\end{array}$ \\
\hline $\begin{array}{l}\text { Columbia Suicide Severity Rating Scale (C- } \\
\text { SSRS) - (Negative) Outpatient. Must be } \\
\text { negative prior to discharge. Will be used } \\
\text { throughout } 12 \text { week therapy. Can be } \\
\text { retaken to reassess feelings of SI } \\
\text { throughout therapy }\end{array}$ & $\mathrm{x}$ & & & & $\begin{array}{l}\text { Identification of SI while on } \\
\text { inpatient psychiatry and } \\
\text { implementation of C-SSRS }\end{array}$ & $x$ & $\mathrm{X}$ & $x$ \\
\hline $\begin{array}{l}12 \text { Week Cognitive Behavioral Therapy- } \\
\text { Suicide Prevention outpatient therapy with } \\
\text { proven reduction of SI and suicidal } \\
\text { attempts evidenced by outcome data and } \\
\text { improvements in quality of life } \\
\text { questionnaire data }\end{array}$ & $\mathrm{x}$ & & & & \begin{tabular}{|l} 
CBT-SP education provided to \\
patient with program \\
descriptive pamphlet
\end{tabular} & \begin{tabular}{|l|} 
\\
Onset of CBT-SP \\
therapy. CBT-SP to \\
be provided by one \\
outpatient provider \\
and group provided \\
by one provider. \\
Weekly review by MH \\
DNP for adherence \\
\end{tabular} & $\begin{array}{l}\text { Continue CBT-SP } \\
\text { therapy. One } \\
\text { provider providing } \\
\text { individual therapy; } \\
\text { one provider } \\
\text { providing group } \\
\text { therapy. Weekly } \\
\text { review by MH DNP } \\
\text { for adherence } \\
\end{array}$ & $\begin{array}{l}\text { Complete } 12 \text { weeks } \\
\text { CBT-SP. By keeping } \\
\text { treatment providers } \\
\text { limited to two } \\
\text { providers, data } \\
\text { collection, reliability } \\
\text { and validity } \\
\text { increased. Weekly } \\
\text { DNP review }\end{array}$ \\
\hline $\begin{array}{l}\text { Decreased hospitalization for sucidial } \\
\text { ideation (SI). At discharge, these patients } \\
\text { will be offered post-discharge CBT-SP } \\
\text { follow-up program, which is } 12 \text { weeks and } \\
\text { will consist of one-one mental health } \\
\text { provider sessions and group therapy. }\end{array}$ & $\mathrm{x}$ & & & & $\mathrm{x}$ & \begin{tabular}{|l|} 
Noticible decrease in \\
hospitalization for SI \\
for this cohort \\
evidenced by chart \\
review
\end{tabular} & $\begin{array}{l}\text { Noticible decrease in } \\
\text { hospitalization for SI } \\
\text { for this cohort } \\
\text { evidenced by chart } \\
\text { review }\end{array}$ & $\begin{array}{l}\text { Noticible decrease in } \\
\text { hospitalization for } \mathrm{Si} \\
\text { for this cohort } \\
\text { evidenced by chart } \\
\text { review }\end{array}$ \\
\hline $\begin{array}{l}\text { Increased outpatient mental health } \\
\text { utilization to include, but not limited to, } \\
\text { substance abuse treatment, depression } \\
\text { treatment, post-traumatic stress disorder } \\
\text { (PTSD) treatment, military sexual trauma } \\
\text { therapy, etc.) }\end{array}$ & $\mathrm{x}$ & & & & $\mathrm{x}$ & $\begin{array}{l}\text { Increase in outpatient } \\
\text { mental health } \\
\text { treatments for this } \\
\text { cohort evidenced by } \\
\text { chart review }\end{array}$ & $\begin{array}{l}\text { Increase in } \\
\text { outpatient mental } \\
\text { health treatments for } \\
\text { this cohort evidenced } \\
\text { by chart review }\end{array}$ & $\begin{array}{l}\text { increase in outpatient } \\
\text { mental health } \\
\text { treatments for this } \\
\text { cohort evidenced by } \\
\text { chart review }\end{array}$ \\
\hline $\begin{array}{l}\text { Patient Quality of Life Tool. Descriptive } \\
\text { questionnaire (baseline and end of } \\
\text { therapy) to assess for improved quality of } \\
\text { life prior to and post-CBT-SP treatment }\end{array}$ & $x$ & & & & $x$ & $\begin{array}{l}\text { Baseline quality of life } \\
\text { assessment tool } \\
\text { given }\end{array}$ & 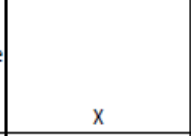 & $\begin{array}{l}\text { Final quality of life } \\
\text { assessment tool given } \\
\text { at completion of } 12 \\
\text { week therapy }\end{array}$ \\
\hline $\begin{array}{l}\text { Provide inpatient and outpatient psychiatry } \\
\text { staff with education about CBT-SP, Suicide } \\
\text { Risk Assessment Clinical Practice } \\
\text { Guidelines, C-SSRS }\end{array}$ & & $X$ & & & $\mathrm{X}$ & $\begin{array}{l}\text { Complete education } \\
\text { and training within } \\
\text { first week }\end{array}$ & $\begin{array}{l}\text { Reinforce education } \\
\text { and training } \\
\text { continually }\end{array}$ & $\begin{array}{l}\text { Monitor and provide } \\
\text { needed education } \\
\text { and training } \\
\text { continually }\end{array}$ \\
\hline
\end{tabular}




\begin{tabular}{|c|c|c|c|c|c|c|}
\hline $\begin{array}{l}\text { Columbia Suicide Rating Scale - Capture } \\
\text { data Inpatient (Positive). The Columbia- } \\
\text { Suicide Rating Scale (C-SSRS) is used to } \\
\text { complete suicide risk assessments on all } \\
\text { patients diagnosed with SI in the VHAThe C- } \\
\text { SSRS is a highly predictive measure of } \\
\text { validity and reliability }\end{array}$ & $\mathrm{x}$ & & \begin{tabular}{l|} 
C-SSRS started in ED and if not \\
completed in ED will be \\
completed on inpatient \\
psychiatric unit
\end{tabular} & \begin{tabular}{|l|} 
Every inpatient \\
psychiatric admitted \\
for SI receives at \\
hosptial admission
\end{tabular} & \begin{tabular}{|l|} 
Will continually \\
provide SI assess- \\
ment throughout \\
treatment and can be \\
regiven as needed to \\
ensure validity and \\
reliability
\end{tabular} & $\begin{array}{l}\text { Will continually } \\
\text { provide SI assess- } \\
\text { ment throughout } \\
\text { treatment and can be } \\
\text { regiven as needed to } \\
\text { ensure validity and } \\
\text { reliability }\end{array}$ \\
\hline $\begin{array}{l}\text { Cognitive Behavioral Therapy - Suicide } \\
\text { Prevention Group (CBT-SP) is theoretically } \\
\text { grounded and incorporates evidence-based } \\
\text { practice principles of psychological therapy } \\
\text { aimed to understand problems associated } \\
\text { with the relationship between thoughts, } \\
\text { physiological sensations, emotions, and } \\
\text { behaviors. The primary goal of CBT-SP is to } \\
\text { prevent future suicidal acts through } \\
\text { educating the patient about the links } \\
\text { between suicidal urges, thoughts, feelings } \\
\text { and associated behaviors }\end{array}$ & $\mathrm{x}$ & & 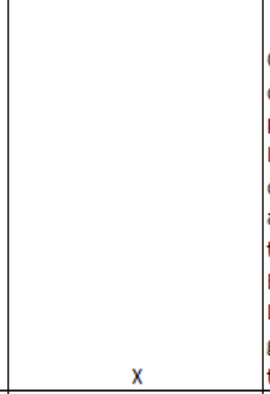 & \begin{tabular}{|l|} 
CBT-SP onset within 7 \\
days of inpatient \\
psychiatric discharge. \\
Individual meeting \\
once a week with \\
available group \\
therapy once a week. \\
Baseline Quality of \\
Life Assessment Tool \\
given at onset of \\
treatment \\
\end{tabular} & \begin{tabular}{|l|} 
\\
Individual CBT-SP \\
therapy once a week \\
with group therapy \\
offered once a week
\end{tabular} & $\begin{array}{l}\text { Individual CBT-SP } \\
\text { therapy once a week } \\
\text { with group therapy } \\
\text { offered once a week } \\
\text { until therapy } \\
\text { completion at } 12 \\
\text { weeks. Final Quality } \\
\text { of Life Assessment } \\
\text { Tool given at end of } \\
\text { treatment } \\
\end{array}$ \\
\hline $\begin{array}{l}\text { Utilization of outpatient mental resources } \\
\text { after inpatient identification and } \\
\text { agreement to begin } 12 \text { week CBT-SP. } \\
\text { Seamless transition of care and follow-up } \\
\text { will be documented in electronic medical } \\
\text { record/chart }\end{array}$ & $x$ & & $x$ & $\begin{array}{l}\text { Electronic chart } \\
\text { record will provide } \\
\text { evidence increased } \\
\text { engagement }\end{array}$ & \begin{tabular}{|l|} 
Electronic chart \\
record will provide \\
evidence of increased \\
engagement
\end{tabular} & $\begin{array}{l}\text { Electronic chart } \\
\text { record will provide } \\
\text { evidence of } \\
\text { continued MH follow- } \\
\text { up and engagement } \\
\end{array}$ \\
\hline $\begin{array}{l}\text { Post Discharge Engagement } 1 \text { for suicide } \\
\text { prevention follow-up (TJC Measure). This } \\
\text { call is to every patient discharged from } \\
\text { inpatient psychiatry with discharge of SI. } \\
\text { Call occurs } 7 \text { days after discharge to ensure } \\
\text { wellness and encourage outpatient mental } \\
\text { health follow-up for SI. Call is monitored } \\
\text { by the VA and mandated by The Joint } \\
\text { Commission }\end{array}$ & $\mathrm{x}$ & & $x$ & \begin{tabular}{|l|} 
Within 7 days of \\
hospital inpatient \\
psychiatric discharge \\
a MH provider calls to \\
monitor wellness and \\
encourage outpatient \\
MH follow-up \\
\end{tabular} & 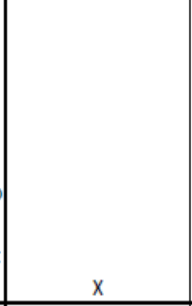 & $\mathrm{x}$ \\
\hline $\begin{array}{l}\text { Potential of patient flow bottle neck in the } \\
\text { Emergency Department. Identifying } \\
\text { patients with suicide ideation (SI) early in } \\
\text { Emergency Department (ED) to inpatient } \\
\text { psychiatry admission and providing } \\
\text { education/information on Cognitive } \\
\text { Behavioral Therapy-Suicide Prevention } \\
\text { (CBT-SP) is essential to reduced attempts of } \\
\text { suicide }\end{array}$ & & $\mathrm{x}$ & $\begin{array}{l}\text { Prompt, accurate } \\
\text { identification of SI patients } \\
\text { from ED to inpatient } \\
\text { psychiatry with a structured } \\
\text { and seamless plan of care } \\
\text { outline in CBT-SP, Clinical } \\
\text { Practice Guidelines. And C- } \\
\text { SSRS will prevent delays } \\
\end{array}$ & $x$ & $x$ & $\mathrm{x}$ \\
\hline
\end{tabular}




\begin{tabular}{|c|c|c|c|c|c|c|}
\hline $\begin{array}{l}\text { Potential of hospital readmission rates for } \\
\text { suicide would increase. CBT-SP } \\
\text { incorporates evidence-based practice } \\
\text { principles of psychological therapy aimed } \\
\text { to understand problems associated with } \\
\text { the relationship between thoughts, } \\
\text { physiological sensations, emotions, and } \\
\text { behaviors. Individual and group sessions } \\
\text { could initially cause increased thoughts of } \\
\text { SI requiring readmission stabilization }\end{array}$ & $\mathrm{x}$ & & & $\begin{array}{l}\text { Decrease in inpatient } \\
\text { readmission for SI to } \\
\text { be monitored weekly } \\
\text { by MH DNP by } \\
\text { electronic chart } \\
\text { review and daily } \\
\text { census }\end{array}$ & $\begin{array}{l}\text { Decrease in inpatient } \\
\text { readmission for SI to } \\
\text { be monitored weekly } \\
\text { by MH DNP by } \\
\text { electronic chart } \\
\text { review and daily } \\
\text { census }\end{array}$ & $\begin{array}{l}\text { Decrease in inpatient } \\
\text { readmission for SI to } \\
\text { be monitored weekly } \\
\text { by MH DNP by } \\
\text { electronic chart } \\
\text { review and daily } \\
\text { census }\end{array}$ \\
\hline $\begin{array}{l}\text { Potential over or under utilization of } \\
\text { outpatient mental health resources. CBT- } \\
\text { SP could become saturated with patients } \\
\text { without available provider resources or not } \\
\text { embraced by outpatients and the } \\
\text { program/intervention not utilized }\end{array}$ & $\mathrm{x}$ & & $\mathrm{X}$ & $\begin{array}{l}\text { Change project will } \\
\text { be staffed by small } \\
\text { group. One MH } \\
\text { provider individual } \\
\text { therapy, one provider } \\
\text { group and DNP MH }\end{array}$ & $\begin{array}{l}\text { Should there be an } \\
\text { increase need for } \\
\text { more providers and } \\
\text { groups, additions can } \\
\text { be made by Chief, } \\
\text { MH Service to } \\
\text { reassign staff }\end{array}$ & $\begin{array}{l}\text { Should CBT-SP be } \\
\text { underutilized, two } \\
\text { providers and one } \\
\text { MH DNP will return } \\
\text { to previous assigned } \\
\text { duties. Success, } \\
\text { expansion to create a } \\
\text { program! }\end{array}$ \\
\hline $\begin{array}{l}\text { Potential disengagement of outpatient } \\
\text { mental health resources. Discussion(s) of } \\
\text { CBT-SP could cause inpatients to avoid } \\
\text { follow-up outpatient suicide intervention }\end{array}$ & $\mathrm{x}$ & & $x$ & \begin{tabular}{|l|} 
Acute inpatient \\
hospitalization $7-14$ \\
days for SI. Goal to \\
encourage out- \\
patient CBT-SP \\
therapy for 12 weeks
\end{tabular} & $\begin{array}{l}\text { Once participating in } \\
\text { therapy goal to } \\
\text { encourage contin- } \\
\text { ued engagement } \\
\text { until completion of } \\
12 \text { week therapy }\end{array}$ & $\begin{array}{l}\text { IRB protocol ensures } \\
\text { partici-pation always } \\
\text { voluntary. Goal } \\
\text { improved quality of } \\
\text { life will maintain } \\
\text { engagement until } 12 \\
\text { weeks complete }\end{array}$ \\
\hline $\begin{array}{l}\text { Patient Quality of Life tool. Descriptive } \\
\text { questionnaire (baseline and end of } \\
\text { therapy) to assess for improved quality of } \\
\text { life post-CBT-SP treatment could indicate } \\
\text { there is no significant difference in data } \\
\text { when analyzed }\end{array}$ & $\mathrm{X}$ & & $\begin{array}{l}\text { Discussion of Quality of Life } \\
\text { Tool to begin 7-14 days while } \\
\text { hospitalized }\end{array}$ & $\begin{array}{l}\text { Baseline quality of life } \\
\text { assessment tool } \\
\text { given to assess pre- } \\
\text { treatment descriptive } \\
\text { quality of life }\end{array}$ & 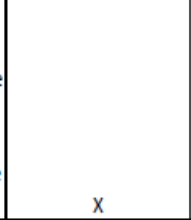 & $\begin{array}{c}\text { Final quality of life } \\
\text { assessment tool given } \\
\text { at completion of } 12 \\
\text { week therapy. Aim to } \\
\text { see significan self- } \\
\text { reported increase in } \\
\text { quality of life }\end{array}$ \\
\hline $\begin{array}{l}\text { Columbia Suicide Rating Scale - (Negative) } \\
\text { Outpatient - free document available to } \\
\text { not only the VA but to community } \\
\text { partners. Accessible via internet with } \\
\text { training tools }\end{array}$ & & \begin{tabular}{|l}
$\$ 0.00$ to take \\
C-SSRS. \\
Hospitaliza- \\
tion \\
$\$ 1,200 /$ day \\
\end{tabular} & $\begin{array}{l}\text { Free suicide risk assess-ment } \\
\text { given all to suicidal psychiatric } \\
\text { inpatients }\end{array}$ & $\mathrm{x}$ & $\mathrm{X}$ & \\
\hline $\begin{array}{l}\text { Cognitive Behavioral Therapy - Suicide } \\
\text { Prevention Group interchange of one } \\
\text { program to CBT-SP. No need for additional } \\
\text { employee/staff. Clinical Practice } \\
\text { Guidelines provide framework for detailed } \\
\text { treatment and follow-up }\end{array}$ & & $\begin{array}{c}\$ 0.00 \text { cost to } \\
\text { the patient. } \\
\text { Provider } \\
\text { salary } \\
\$ 80,000 / \text { year }\end{array}$ & $\mathrm{x}$ & $\begin{array}{l}\text { Department of } \\
\text { Veterans Affairs (VA) } \\
\text { National Strategy for } \\
\text { Preventing Veteran } \\
\text { Suicide: } 2018-2028, \text { is } \\
\text { very clear in its } \\
\text { mission of treating } \\
\text { suicide }\end{array}$ & $\begin{array}{l}\text { VA has Clinical } \\
\text { Practice Guidelines } \\
\text { for Suicide Risk } \\
\text { Assessment, } \\
\text { C-SSRS, CBT-SP and } \\
\text { multiple free } \\
\text { education, training } \\
\text { and resources to } \\
\text { treat SI }\end{array}$ & $\begin{array}{l}\text { VA staff at Tampa VA } \\
\text { are not currently } \\
\text { providing CBT-SP. } \\
\text { Goal of change } \\
\text { project to provide } \\
\text { evidence based } \\
\text { therapy to frontline } \\
\text { MH providers to } \\
\text { reflect effacacy of } \\
\text { CBT-SP }\end{array}$ \\
\hline $\begin{array}{l}\text { Increased outpatient mental health } \\
\text { utilization (i.e. individual psychotheapy, } \\
\text { psychopharmachology, family therapy, } \\
\text { etc.) Major savings in hospital readmissions } \\
\text { and quality of life benefits to the patients } \\
\text { with access to other mental health } \\
\text { resources }\end{array}$ & & $\begin{array}{c}\$ 0.00 \text { cost to } \\
\text { the patient. } \\
\text { Hospital } \\
\text { readmission } \\
\text { savings } \\
\$ 1,200 / \text { day }\end{array}$ & $\mathrm{X}$ & $\begin{array}{l}\text { Major depression, } \\
\text { substance abuse, } \\
\text { military sexual } \\
\text { trauma, PTSD are } \\
\text { some causes of SI. } \\
\text { Outpatient therapy } \\
\text { for SI will decrease } \\
\text { readmission rates }\end{array}$ & $\begin{array}{l}\text { Readmission rates } \\
\text { are tracked and } \\
\text { trended by the VA } \\
\text { and report monthly } \\
\text { to hospital leader- } \\
\text { ship }\end{array}$ & $\begin{array}{l}\text { Continuous monthly } \\
\text { monitor-ing of } \\
\text { decreased admission } \\
\text { rates of this cohort of } \\
\text { SI patients will add to } \\
\text { the change plan } \\
\text { Business Case for } \\
\text { program change }\end{array}$ \\
\hline
\end{tabular}




\begin{tabular}{|c|c|c|c|c|c|}
\hline $\begin{array}{l}\text { Cost involved with educating staff on C- } \\
\text { SSRS, CBT-SP, Clinical Practice Guidelines } \\
\text { for Suicide Risk Assessment, patient } \\
\text { educational materials, information } \\
\text { pamphlets, etc. }\end{array}$ & $\begin{array}{c}\$ 0.00 \text { cost to } \\
\text { the patient. } \\
\text { Hospital costs } \\
\text { for materials } \\
\$ 0.00 \\
\end{array}$ & $\begin{array}{l}\text { Resources are free and readily } \\
\text { available to all medical } \\
\text { providers. There are } \\
\text { additional VA specific } \\
\text { resources also free to VA } \\
\text { employees. Patient education } \\
\text { resources avail. }\end{array}$ & $\begin{array}{l}\text { CBT-SP, C-SSRS and } \\
\text { Clinical Practice } \\
\text { Guidelines, etc } \\
\text { provided at no cost } \\
\text { to the employee or to } \\
\text { the patient }\end{array}$ & $\begin{array}{l}\text { CBT-SP, C-SSRS and } \\
\text { Clinical Practice } \\
\text { Guidelines, etc } \\
\text { provided at no cost } \\
\text { to the employee or } \\
\text { to the patient } \\
\end{array}$ & $\begin{array}{l}\text { CBT-SP, C-SSRS and } \\
\text { Clinical Practice } \\
\text { Guidelines, etc } \\
\text { provided at no cost to } \\
\text { the employee or to } \\
\text { the patient }\end{array}$ \\
\hline $\begin{array}{l}\text { Patient Quality of Life Tool. Quality of life } \\
\text { assessment tools are free and available to } \\
\text { providers to measure descriptive data. The } \\
\text { same questionnaire will be asked at onset } \\
\text { of intervention then again at the end of } 12 \\
\text { week therapy }\end{array}$ & $\begin{array}{l}\$ 0.00 \text { cost to } \\
\text { the patient. } \\
\$ 0.00 \text { cost to } \\
\text { the assessing } \\
\text { provider }\end{array}$ & \begin{tabular}{|l|} 
Various and multiple \\
descriptive quality of life \\
tools. Will use a baseline tool \\
to assess SI patient quality of \\
life. Disucssion of tool to \\
begin within 7-14 days
\end{tabular} & $\begin{array}{l}\text { Various and multiple } \\
\text { descrip-tive quality of } \\
\text { life tools. Will use a } \\
\text { baseline tool to } \\
\text { assess SI patient } \\
\text { quality of life. }\end{array}$ & 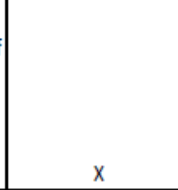 & $\begin{array}{l}\text { Will use to same tool } \\
\text { used at the onset of } \\
\text { therapy to } \\
\text { compare/contrast } \\
\text { patient quality of life } \\
\text { at the end of therapy }\end{array}$ \\
\hline
\end{tabular}




\section{Appendix G}

Columbia Suicide Severity Risk Scale (C-SSRS)

\section{C-SSRS Secondary Screen}

1. Over the past month, have you wished you were dead or wished you could go to sleep and not wake up?

$\square$ Yes $\quad$ Proceed to question \#2 regardless of response.

2. Over the past month, have you had any actual thoughts of killing yourself?

$\square$ Yes If 'Yes', proceed to question \#3

$\square$ No If ' $N o$ ', proceed to question \#7

3. Over the past month, have you been thinking about how you might do this?

$\square$ Yes Proceed to question \#4 regardless of response.

$\square$ No

4. Over the past month, have you had these thoughts and had some intention of acting on them?

$\square$ Yes Proceed to question \#5 regardless of response.

$\square$ No

5. Over the past month, have you started to work out or worked out the details of how to kill yourself?

$\square$ Yes If 'Yes', proceed to question \#6

$\square$ No If 'No', proceed to question \#7

6. If yes to Q5, at any time in the past month did you intend to carry out this plan?

$\square$ Yes $\quad$ Proceed to question \#7 regardless of response.

$\square$ No

7. In your lifetime, have you ever done anything, started to do anything, or prepared to do anything to end your life (for example, collected pills, obtained a gun, gave away valuables, went to the roof but didn't jump)?

$\begin{array}{ll}\square \text { Yes } & \text { If ' Yes', proceed to question \#8 } \\ \square \text { No } & \text { If 'No', proceed to scoring }\end{array}$

8. If yes to $Q 7$, was this within the past 3 months?

$\square$ Yes

$\square$ No

Scoring:

A positive C-SSRS (Columbia) score is a 'Yes' response to items $3,4,5$, or 8.

If a positive screen has been determined, administration of the VA Comprehensive Suicide Risk Evaluation template must be completed on the same day by an LIP. 